\title{
THE CURSE AND Blessing OF TRAINING THE
}

\section{UNEMPLOYED IN A CHANGING ECONOMY: THE}

\section{CASE OF EAST GERMANY AFTER UNIFICATION}

\author{
Michael Lechner, Ruth Miquel and Conny Wunsch* \\ SIAW

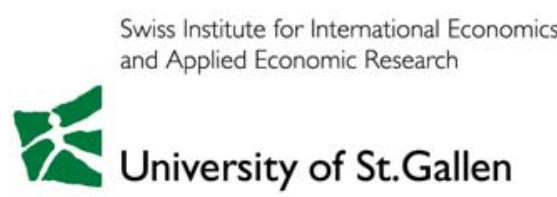

First version: May, 2005

Date this version has been printed: 14 February 2006

\begin{abstract}
We analyse the effects of government-sponsored training for the unemployed conducted during East German transition. For the microeconometric analysis, we use a new, large and informative administrative database that allows us to use matching methods to address potential selection bias, to study different types of programmes, and to observe labour market outcomes over 8 years. We find strong evidence that, on average, the training programmes under investigation increase long-term employment prospects and earnings. However, as an important exception, the longer training programmes are not helpful for their male participants. At least part of the explanation for this negative result is that caseworkers severely misjudged the structure of the future demand for skills.
\end{abstract}

Keywords: Active labour market policy, nonparametric identification, matching estimation, causal effects, programme evaluation, panel data, gender differences

JEL classification: $\mathrm{J} 68$

Address for correspondence: Michael Lechner, Swiss Institute for International Economics and Applied Economic Research (SIAW), University of St. Gallen, Bodanstr. 8, CH-9000 St. Gallen, Switzerland, Michael.Lechner@unisg.ch,www.siaw.unisg.ch/lechner.

* The first author is also affiliated with CEPR, London, ZEW, Mannheim, IZA, Bonn, and PSI, London. Financial support by the Institut für Arbeitsmarkt- und Berufsforschung (IAB), Nuremberg, Germany (project 6-531A), is gratefully acknowledged. Conny Wunsch is also grateful for financial support from the IAB (thesis grant). The data originated from a joint effort with Stefan Bender, Annette Bergemann, Bernd Fitzenberger and Stefan Speckesser to make various German administrative data bases usable for econometric research. The paper has been presented at two conferences at the IAB (Nuremberg, Summer 2005), at a conference of the COST A23 network in Paris, at the ADRES conference in Paris as well as in seminars at the University of St. Gallen. We thank participants, in particular Stefan Bender and Barbara Sianesi, for helpful comments and suggestions. The usual disclaimer applies. The interested reader will find additional background material for this paper in a much longer discussion paper version of the paper as well as in an internet appendix, both of which are available on our website www.siaw.unisg.ch/lechner/lmw_fuu_ost. 


\section{Introduction}

In the course of the monetary, economic and social union in July 1990, East Germany adopted most of the regulations that govern economic life from West Germany (currency, legal order, wage structure, social system, etc.). Transitional arrangements were rare. For example, a low wage policy by devaluating the currency, as used by other transitions countries, was not possible. As a result, the formerly centrally planned East German economy - almost over night - faced the conditions of a modern Western-style market economy. Until December 1990, production of goods dropped to only 50\% of its 1989 level and unemployment rose rapidly (Akerlof, Rose, Yellen and Hessenius, 1991). To accommodate the dramatic developments in the East German labour market, the German government used active labour market policies (ALMP) on a massive scale. At its peak in 1992, expenditures for ALMP summed up to more than $9 \%$ of East German GDP.

As part of the ALMP, government-sponsored training played an important role in adjusting the skills of the East German labour force, which had become largely obsolete under the new system, to the requirements of a modern market economy. A common feature of these training programmes was that, usually, the human capital investment was substantial. Durations of one or two years were not unusual. Some courses had durations of up to three years.

Here, we analyse the short- and long-run effects of government-sponsored training for the unemployed conducted in the period 1993-1994. Our findings point to two major issues. First, to fully understand the impact of training programmes on labour market outcomes, it is important to study short- and long-run effects of training programmes. Those effects may be distinctively different particularly for longer programmes. The importance of long-run effects was emphasised for Western market economies by e.g. Couch (1991), Hotz, Imbens and Klerman (2000), Jacobson, LaLonde and Sullivan (2004), Jesperson, Munch and Skipper (2004), Lechner, Miquel and Wunsch (2004), and Winter-Ebmer (2001). All these studies 
agree that positive long-run effects of training are likely (as opposed to the previous literature, which, based on shorter follow-up periods, could not agree on any likely sign of the training effects; see e.g. Martin and Grubb, 2001). Our results confirm this view. Furthermore, we find negative lock-in effects in the short-run that are directly related to programme duration. Thus, following the evolution of the effects over time is crucial for understanding the impact of the programmes on individual labour market performance.

Second, we find considerable effect heterogeneity among participants as well as across types of programmes. In particular, we find no or even negative employment effects of longer training programmes for men, but positive effects for women. These gender differences occur because men and women were trained for different occupations. Unfortunately, many caseworkers misjudged the future demand for skills; the majority of male participants were trained towards occupations in the construction sector (about $70 \%$ of participants in the longest programme). Construction experienced a boom in the early 1990s (when caseworkers made their decision) but went into bust soon after the courses were completed. Thus, the blessing of having obtained funding for long vocational training became a curse for its participants. This finding pinpoints the importance of correct targeting of training and other ALMP measures, which is of course particularly difficult in a rapidly changing economy.

Earlier studies that analyse government-sponsored training in East Germany were not able to address these issues. Although evidence for other transition countries like Poland (O'Leary, 1998b; O'Leary, Kolodziejczyk and Lázár, 1998; Puhani, 1999; Kluve, Lehmann and Schmidt, 1999, 2004) ${ }^{1}$, the Slovak Republic (Lubyova and Van Ours, 1999) and Hungary (O'Leary, 1998a; O'Leary, Kolodziejczyk and Lázár, 1998) suggests that training programmes succeeded in raising individual employment probabilities of participants, the evidence for East Germany is mixed, so far. The earlier studies for East Germany use survey data that are rather limited with respect to the length of the observation period, sample size and the avail- 
ability of sufficiently detailed information to account for selectivity and programme heterogeneity. ${ }^{2}$ Most of these studies use parametric models ${ }^{3}$ and find negative or insignificant shortto medium-term employment effects (e.g. Pannenberg, 1995; Hübler, 1998, Hujer and Wellner, 2000), but there are also studies that obtain positive effects (e.g. Pannenberg and Helberger, 1997; Prey, 1999). The lack of robustness is due to the sensitivity of the results to different parametric assumptions, small sample sizes, and the inability to measure long-run effects.

Recent evidence based on new administrative data shows that negative lock-in effects during and shortly after programme participation are important in East Germany. Hujer, Thomsen and Zeiss (2004) estimate a multivariate mixed proportional hazard rate model to analyse the effects of government-sponsored training conducted in the period 2000-2002 on the transition rate into regular employment. Because of the short time horizon available to observe outcomes, the negative lock-in effects drive their results. Speckesser (2004) and Fitzenberger and Speckesser (2005) draw their sample from the same administrative records than we do. However, they restrict their analysis to one special type of government-sponsored training and observe outcomes for 36 months after the beginning of the programme only, compared to 96 months in this study. Based on propensity score matching, they find negative lock-in effects up to 12-18 months after programme start. Speckesser (2004) who focuses on training conducted in the period 1993-1994 finds no significant effects thereafter, mainly because of rapidly decreasing sample size towards the end of his observation period. Fitzenberger and Speckesser (2005), who cover a longer period of programme participation (1990-1997), obtain positive employment effects of about 5-10 percentage points about 20 months after programme start.

1 Earlier studies of Puhani (1996) and Puhani and Steiner (1997) find, however, no significant effects.

2 Pannenberg (1995), Pannenberg and Helberger (1997), Fitzenberger and Prey (1998, 2000), Hübler (1997, 1998), Staat (1997), Kraus, Puhani and Steiner (1999), Lechner (1999, 2000), Prey (1999), Hujer and Wellner (2000), Bergemann, Fitzenberger and Speckesser (2004). These studies use the German Socioeconomic Panel or the Labour Market Monitor East or for Saxony-Anhalt (see the survey by Wunsch , 2005). 
Altogether, we extend the literature in several dimensions. First, using a newly available administrative database allows us to measure the effects of different training programmes over 8 years, thereby uncovering the potentially important long-run effects of substantial government-sponsored training programmes and distinguishing these effects from the lock-in effects that occur in the short-run. Second, we check the heterogeneity across programmes and groups of participants which enables us to add to the discussion of correct targeting of ALMP measures. Third, the database is particularly rich with respect to information concerning the selection process, so we can address selection issues in a reasonable way. Finally, the sample used is large enough to allow non- or at least semi-parametric estimation of the effects using matching methods.

The remainder of the paper is organised as follows: In the next section, we outline those parts of the active labour market policies in East Germany that are important for our paper. Section 3 describes our data. Section 4 outlines our econometric strategy. Section 5 presents the main results as well as a summary of an extensive sensitivity analysis. Section 6 concludes. Two appendices provide additional information on the data and the estimation procedure.

\section{$2 \quad$ Labour market policies in East Germany}

\subsection{The use of ALMP during East German transition}

The rapid contraction of the East German economy after unification led to sharp reductions in labour demand. To cope with the immediate strongly adverse effects of this, different instruments of ALMP were used. Immediately after unification, short-time work (a reduction in work hours combined with a subsidy from the unemployment insurance system to compensate the earnings loss) and early retirement schemes played a major role. In East Germany, especially in 1991, the main objective of short-time work was to delay the transition into unem-

3 Semi- or non-parametric approaches are used by Lechner (1999, 2000), Hujer and Wellner (2000) and Bergemann, Fitzenberger and Speckesser (2004). 
ployment to prevent the official unemployment rate from skyrocketing. In that year, more than 1.6 million people were directly absorbed into short-time work (see Table 1).

Since the skills of the labour force did not meet the requirements of a modern market economy, different kinds of training programmes were introduced on a large scale to lessen these skill deficits. In 1991, 800,000 individuals participated in some form of labour market training. Since then, the number of participants has declined, but with 468,000 participants in 2003, training is still the most important ALMP programme in East Germany.

Table 1: Participants in the quantitatively most important ALMP measures 1991-2003

\begin{tabular}{|c|c|c|c|c|c|c|c|}
\hline & 1991 & 1993 & 1995 & 1997 & 1999 & 2001 & 2003 \\
\hline Training a) & 760 & 263 & 237 & 155 & 350 & 415 & 468 \\
\hline Temporary wage subsidies a) & 133 & 31 & 20 & 11 & 65 & 99 & 107 \\
\hline Employment programmes ${ }^{\mathrm{b})}$ & 183 & 237 & 206 & 154 & 348 & 190 & 110 \\
\hline Short-time work b) & 1616 & 181 & 71 & 49 & 27 & 27 & 35 \\
\hline Early retirement $\mathrm{b}$ ) & 189 & 639 & 341 & 58 & - & - & - \\
\hline Unemployment rate in \% & 10.2 & 15.4 & 14.8 & 19.1 & 18.7 & 18.8 & 20.1 \\
\hline
\end{tabular}

Sources: BA (1992-2004).

Notes: a) Total number of inflows (1000 persons). b) Yearly average (1000 persons).

A third type of ALMP was subsidised employment which comprised temporary wage subsidies to compensate for reduced productivity during the phase of initial skill adaptation in a new job, and so-called employment programmes which provided subsidised jobs outside the regular labour market. In times of high and persistent unemployment, employment programmes are supposed to be an important measure to maintain the employability of unemployed and especially long-term unemployed persons, as well as to preserve social stability in regions with particularly high rates of unemployment.

\subsection{Training as a part of German ALMP}

In Germany, labour market training consists of very heterogeneous instruments that differ largely in the form and intensity of the human capital investment as well as in their respective duration. Traditionally, German training courses have the aim of assessing, maintaining or improving the occupational knowledge and skills of the participant, of adjusting skills to 
technological changes, of facilitating a career improvement, or of awarding a first professional degree. In the East German transition process, however, the use of the two latter categories was negligible since the main objective of training programmes was to adjust the skills of the East German labour force to the requirements of a modern market economy. Usually, participants in such training programmes receive a transfer payment that is of the same amount as unemployment benefits. ${ }^{4}$ Moreover, the public employment service (PES) bears the direct cost of the programme, and it may cover parts of additional expenses for childcare, transportation and accommodation.

For our analysis, we aggregate the different programmes into groups according to their homogeneity with respect to selection of participants, educational contents and organisation, as well as sample size and information available to distinguish different types of programmes. Table 2 shows the resulting groups of training programmes plus a residual category. Ignoring the programme types for which the number of observations is too small, we restrict our analysis to general further vocational training and retraining programmes.

Further training comprises courses that provide a general adjustment of working skills or an additional qualification in the profession currently held, as well as courses that award a first professional degree. Planned durations range from one month to two years (cf. Figure 1). Since further training is a fairly large and heterogeneous group, we split it into two subgroups based on the planned duration of an individual course. As a characterisation of the programme and not its participants, planned instead of actual duration has the advantage that the behaviour of the individual during participation does not influence it (e.g. a short actual duration could be associated with a short course or a long course that a participant left early). Retraining enables working in a different profession than the one currently held by awarding a new professional degree. Planned durations are long (up to three years, 21 months on average).

\footnotetext{
4 Before 1994, the replacement rate was somewhat higher than for unemployment benefits.
} 
The acquired skills are equivalent to an apprenticeship in the German apprenticeship system.

Thus, the human capital investment is quite substantial.

Table 2: Definition of programmes

\begin{tabular}{|l|l|}
\hline \hline Programme & Description \\
\hline Short training & Further training in the profession held with planned duration $\leq 6$ months. \\
\hline Long training & Further training in the profession held with planned duration $>6$ months. \\
\hline Retraining & Training to obtain a new professional degree in a field other than the profession currently held. \\
\hline Other programmes & $\begin{array}{l}\text { Practice firm: Further training that simulates a job in a specific field of profession } \\
\text { Career improvement: Further training to obtain a higher professional degree, e.g. master crafts- } \\
\text { man, technician, or a (below university) degree in business administration. } \\
\text { Residual category: Various very small and heterogeneous programmes. }\end{array}$ \\
\hline
\end{tabular}

Note: Due to insufficient sample size the category other programmes is not evaluated in this study.

Figure 1: Distribution of the planned programme duration in our data
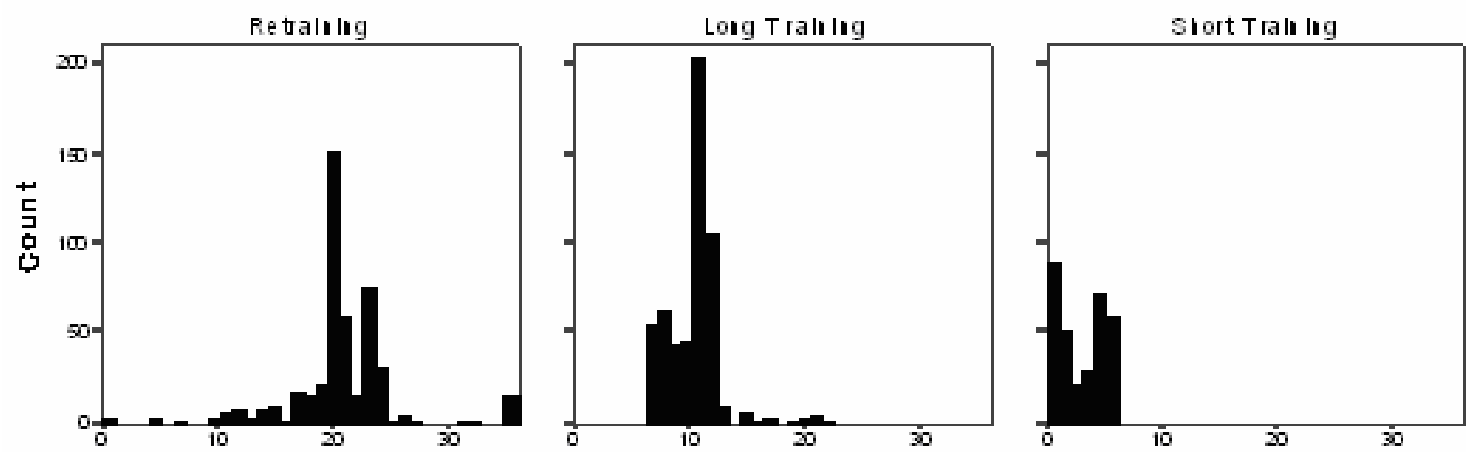

Months of planned programme duration

Note that generally, the German programmes are long on average compared to other OECD and transition countries (e.g. OECD, 1996a, b). Moreover, most training courses are full-time courses, and in addition to classroom training, a course may include on-the-job training which is frequently the case in courses that award a professional degree.

\section{Data and definition of the evaluation sample}

\subsection{The data}

We use the same administrative database as in Lechner, Miquel and Wunsch (2004) and refer the reader to that paper for more details. It combines three different sources: the IAB Em- 
ployment Subsample, the benefit payment register, and the training participants data. ${ }^{5}$ For East Germany, it covers the period 1990-2002. With this database, we are able to reconstruct up to 12 years of individual post-unification employment histories. It contains detailed personal, regional, employer and earnings information (see Appendix A for a complete list of variables). Thus, it allows controlling for many if not most of the factors that determine selection into programmes (see the detailed discussion in Section 4.2) as well as a precise measurement of interesting outcome variables (e.g. employment status, earnings). Moreover, we are able to distinguish different programme types and it has a sufficient number of observations for the major programme groups to account for programme heterogeneity.

Of course, there are several drawbacks as well. First, the data do not cover nonworking recipients of social assistance because they do not receive benefits from the PES but from the local authorities. Second, employment that is not subject to social security contributions is unobserved. On the one hand, this includes self-employment and working as a civil servant ("Beamter"). On the other hand, this regards minor employment below the relevant earnings threshold. Third, it is possible to distinguish between subsidised and regular employment only from the year 2000 onwards. This problem is particularly severe for East Germany, because a substantial part of the labour force were in subsidised employment during the 1990s (see Table 1). Fourth, the training information for East Germany prior to 1993 is incomplete and not correctly coded. Fifth, the unification process had a direct impact on the data gathering process. Data collection, which depends to a considerable part on reports from employers, was phased in after unification. Some employers provided information as early as 1991 whereas in most cases it took until 1992 until all employers were registered with the authorities. Therefore, our sample is selected on either having an initial employment or unemploy-

\footnotetext{
5 The common German abbreviations for these data sources are IABS, LED and FuU, respectively. A detailed description of the IABS and the LED is provided by Bender et al. (1996) and Bender, Haas and Klose (2000). For the FuU see Miquel, Wunsch and Lechner (2002). See also Bender et al. (2005) for how the data has been prepared for evaluation purposes.
} 
ment spell in the data. Thus, later on, we condition on having observed an employment spell prior to the unemployment spell leading to participation. The sixth drawback is that information about long-term employment histories is absent. However, since in the German Democratic Republic unemployment was (officially) absent and labour force participation was very high, the resulting additional unobserved heterogeneity should be very small, in particular since unification per se certainly discounted the value of human capital and experience obtained under the old centrally planned economic system.

Despite these drawbacks, compared to what was used in the literature so far, this database is a substantial improvement in several dimensions, like sample size, selection and outcome information, as well as observable programme heterogeneity.

\subsection{Definition of programme participation}

In this section, we define 'participation in a programme' and our population of interest. First, since the programme participation data is of good quality only after 1992, we consider programme participation between 1993 and 1994. By choosing this period, we are able to focus on the most recent programmes that still allow for a long enough observation period for detecting long-run effects. ${ }^{6}$ Second, a person is included in our population of interest if he starts an unemployment spell between 1993 and 1994. The group of participants in training consists of all persons entering a programme between the beginning of the first unemployment spell after 1992 and the end of 1994. If there are multiple participations in this period, then only the first one is included in the analysis.

The left panel of Figure 2 shows the distribution of starting months in the two-year window we consider. Partly due to the construction of our sample, the probability of treatment increases over time. The right panel of Figure 2 shows the number of months it takes until

\footnotetext{
6 Furthermore, since we observe only training spells after the participant left training, and some courses have a duration of more than two years, and there is no training information after 1997, concentrating on the years 1993 and 1994 does not lead to a selective underrepresentation of long training spells.
} 
participation after the beginning of the 'defining' unemployment spell (the first UE spell between 1993 and 1994). From the latter graph it seems that a considerable group of trainees enter training fairly (surprisingly) early in the spell, particularly for retraining.

Figure 2: Distribution of start dates and duration until start of programmes (in \%)
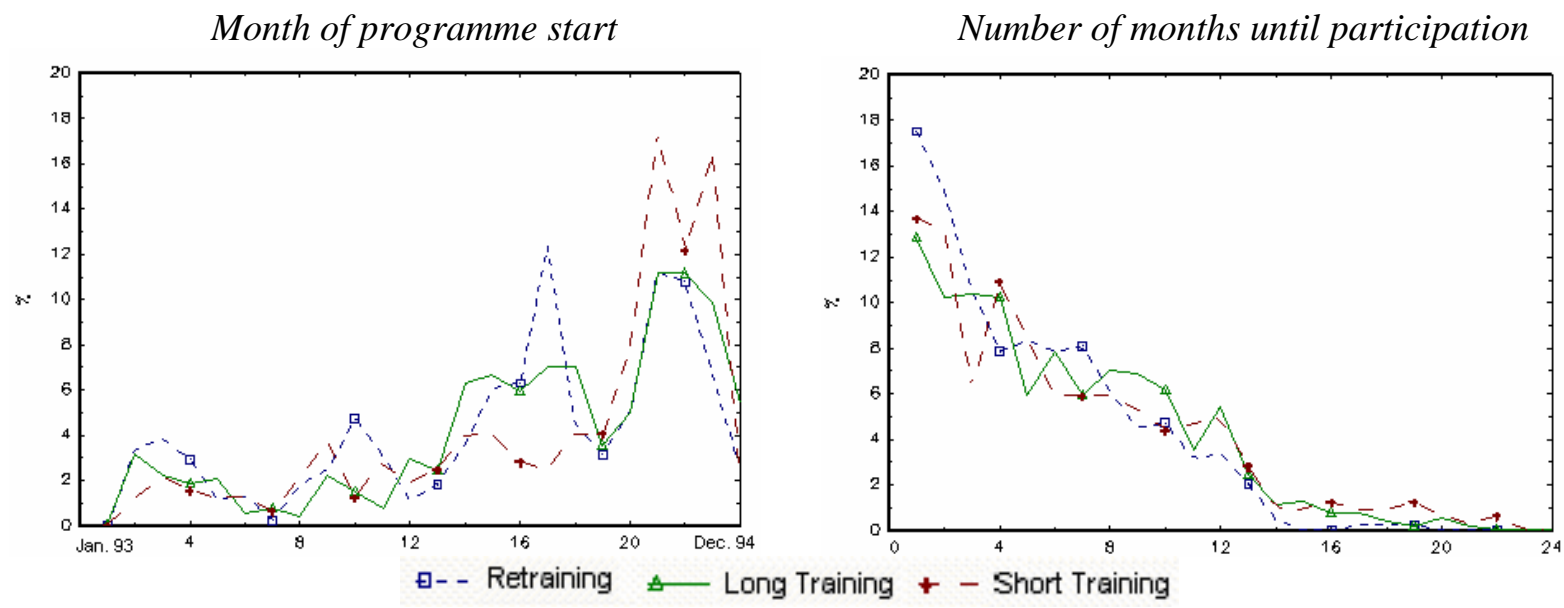

Note: Monthly measurement based on estimation sample for participants.

Given our definition of a small treatment window (although often much smaller windows are used in the literature, e.g. Dorsett, 2005), and taking up the arguments in Fredriksson and Johansson (2003, 2004) it is particularly important for the interpretation of our results which share of the control groups receives treatment as well (similar to the problem of substitution bias in an experiment). The fact that we condition nonparticipation on ending unemployment without entering a programme (or not ending unemployment at all) before 1995 might lead to some bias in our results in favour of the so-defined nonparticipation status. This bias should be severe if nearly every unemployed has to participate. However, Table 3 shows that only about $17 \%$ of those classified as nonparticipants receive some training between 1995 and 1997 (the participation information in that database ends 1997). ${ }^{7}$

From Table 3 we also see that second or further participations ('programme careers') appear not to be a major problem for the interpretation of our results. Less than $20 \%$ of the trainees

\footnotetext{
7 Also note that the approach suggested by Fredriksson and Johansson (2003, 2004) as applied e.g. by Sianesi (2004) or Steiger (2004) estimates a different causal effect which is not of particular interest in our study.
} 
participate a second time, often in the same programme type as they already participated in. ${ }^{8}$ The conceptual problem with analysing the effect of e.g. the second participation is that the second participation may be influenced by the success of the first programme. Thus, such an analysis of the effects of sequences of programmes requires a dynamic evaluation approach as suggested by Lechner and Miquel (2005) and Lechner (2004), which is not feasible with our data without further aggregation of programme types, which, in turn, is undesirable for obvious reasons.

Table 3: Participation in different programme types in \% of participants in subsamples until 1997

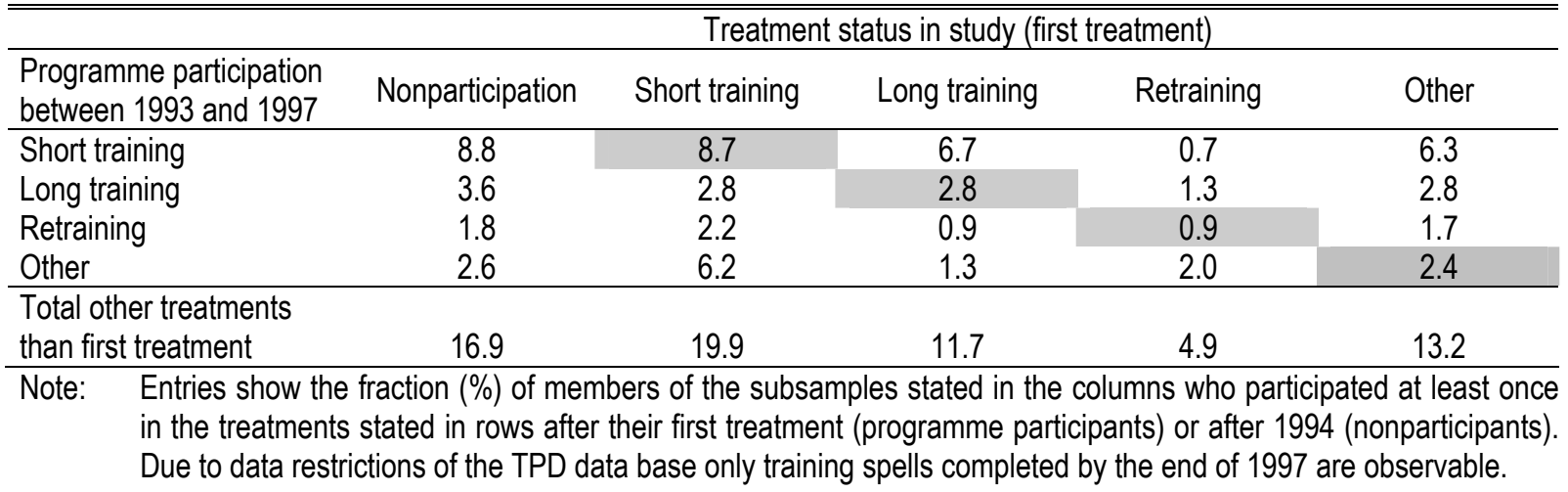

\subsection{Selection of population and sample}

When choosing the appropriate subpopulation from our inflow sample into unemployment, we aim at having a homogenous group of people that covers the prime age part of the East German population who is eligible for participation in training. Therefore, we require that all individuals were employed ${ }^{9}$ at least once before programme participation and that they received unemployment benefits (UB) or assistance (UA) in the month before programme start (as well as in the month of programme start for nonparticipants). ${ }^{10}$ This, however,

8 Overall, about 20\% of registered unemployed enter government-sponsored training per year (BA, 1992-2004).

9 'Employed' means that we observe the person at least once in insured employment in the IABS (for the majority of our individuals, the first observation in the data is an employment spell).

${ }^{10}$ In fact, receipt of UB or UA directly before entering a programme is not entirely sufficient to ensure eligibility. Individuals must also have a formal professional degree plus three years of work experience (since 1994, zero years), or alternatively at least six years (since 1994, three years) of work experience. Thus by also requiring individuals to be employed at least once before the programme, the remaining group of participants and nonparticipants is most likely to be eligible. 
requires the use of variables measured relatively to the start date of the programme. ${ }^{11}$ In this paper, we follow one of the approaches suggested by Lechner (1999). We simulate start dates for nonparticipants by drawing start dates from the empirical distribution for participants and then ensuring that this date does not lie before the beginning of the 'defining' UE spell, or after 1994 or of the person's last spell that is observed in the data if it ended before $1995 .{ }^{12}$

To avoid most influences coming from retirement, early retirement and primary education, we also impose an age restriction (20-53 years) in the year of the (hypothetical) programme start. Concentrating on the main body of the active labour force, we exclude unemployed who were trainees, home workers, apprentices or without previous employment or whose last employment before the 'defining' UE spell was less intensive than half of the usual full-time work hours. Furthermore, since the group of foreigners is extremely heterogeneous in East Germany (there is no 'stable' and at least partly assimilated guest worker population, as in West Germany), we drop them as well.

Table 4: Sample selection rules and resulting sample sizes

\begin{tabular}{|c|c|c|c|c|c|}
\hline & $\begin{array}{l}\text { Nonpar- } \\
\text { ticipation }\end{array}$ & $\begin{array}{c}\text { Short } \\
\text { Training }\end{array}$ & $\begin{array}{l}\text { Long Train- } \\
\text { ing }\end{array}$ & "Retraining & Other \\
\hline $\begin{array}{l}\text { Persons entering unemployment } \\
\text { between Jan. ' } 93 \text { and Dec. ' } 94\end{array}$ & 17574 & 418 & 692 & 531 & 383 \\
\hline \multicolumn{6}{|c|}{ Simulated programme start after the entry in unemployment and before the end of the observation period } \\
\hline Remaining observations & 12904 & 418 & 692 & 531 & 383 \\
\hline \multicolumn{6}{|c|}{$\begin{array}{l}\text { Eligibility: Only individuals receiving UB or UA in the month before the programme start } \\
\text { (also in the month of the programme start for nonparticipants) }\end{array}$} \\
\hline Remaining observations & 6599 & 400 & 656 & 496 & 350 \\
\hline \multicolumn{6}{|c|}{$\begin{array}{l}\text { Personal characteristics : a) } 20 \leq \text { age } \leq 53 ; \text { b) no trainees or apprentices; c) at least one observation of } \\
\text { employment; d) no home workers; e) no part-time worker less than half of a full-time work; f) only German }\end{array}$} \\
\hline Final sample & 4604 & 321 & 538 & 445 & 288 \\
\hline
\end{tabular}

\footnotetext{
${ }^{11}$ Moreover, all variables potentially influencing both selection into programmes and outcomes are measured relatively to the start of the programme.

12 Nonparticipants who do not satisfy this criterion are excluded. We tested an alternative procedure for assigning hypothetical start dates to nonparticipants. We randomly draw from the empirical distribution of elapsed unemployment durations before programme start of participants and check whether the respective nonparticipant has at least the same unemployment duration. If so, we assign as hypothetical starting date the month after the drawn unemployment duration. Our results remain almost unchanged (see Section 5.4).
} 
Table 4 shows how the sample shrinks when imposing these criteria. The largest drop in the number of observations occurs for nonparticipants to make them a priori comparable to the treated using the criteria above, which they have to fulfil at the simulated start date. However, since we still keep almost 5,000 unemployed nonparticipants, the large reduction is of no serious concern. The reduction for participants is small (about $20 \%$ on average).

\subsection{Descriptive statistics}

Table 5 shows descriptive statistics for selected socio-economic variables for the different subsamples that are defined by treatment status.

Table 5: Selected descriptive statistics according to participation status (means or shares in \%)

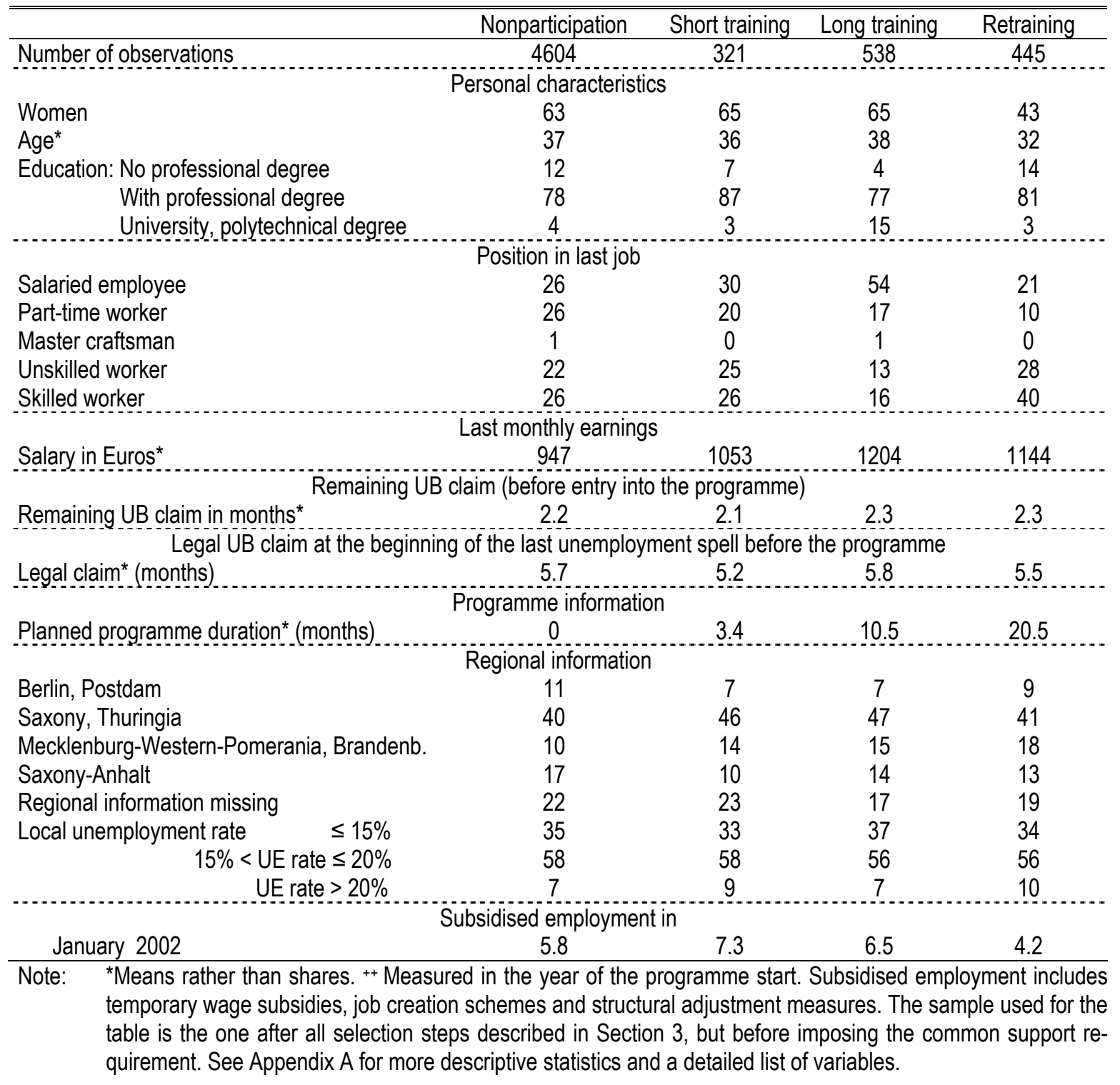


The results can be summarised as follows: (i) Participants in retraining are on average 32 years old and thus on average about five years younger than other unemployed. This is in line with the idea that substantive human capital investments are more beneficial the longer the productive period of the new human capital is. (ii) Participants in retraining are less educated and skilled than the rest. (iii) Participants in short and particularly participants in long training are better educated and were in higher job positions in their previous job than the rest. (iv) Remaining unemployment benefit (UB) claims before participation do not show much variation. (v) The share of women among the unemployed is much higher in East Germany than for example in West Germany, which is reflected in their high share among nonparticipants and participants in long and short training, but not in their share observed in retraining which shows a 'male' bias. (vi) There are some regional differences that, however, do not appear to be related to the local unemployment rate (see Appendix A for a list of more disaggregated regional). (v) Finally, in 2002 subsidised employment is still a considerable part of employment (about 15\% of all employment is subsidised; this information is unavailable before 2000 and incomplete for 2000-2001). Furthermore, Table A.1 in the Appendix shows that only very few people in our evaluation sample participated in a programme before the programme participation we are evaluating.

Figure 3 displays the time path of (subsidised and unsubsidised) employment and unemployment rates for the different groups of participants and nonparticipants relative to the actual or simulated beginning of the training. By construction of the sample, all members of these groups must be unemployed in the month before participation. Thus, the unemployment and employment rates show the usual increase/dip before participation (cf. Ashenfelter, 1978). Furthermore, note that all individuals must be employed at some point in time prior to the unemployment spell in which participation happens. Thus, there is a sharp increase in unemployment rates starting about one year before participation and a corresponding decline in employment rates. 
After the programme, all employment measures show some recovery. The immediate speed of the recovery is negatively related to programme duration, pointing to a lock-in effect of participation (cf. Van Ours, 2004). None of the groups reaches its previous level, but the rate of recovery for nonparticipants is particularly low, already foreshadowing the results of the econometric part below. Note the interesting difference that appears between unemployment and employment. Both measures of labour market attachment show the same shape over time. However, for registered unemployed (defined as receipt of some form of benefits or participation in training) there does not appear to be any difference between the different groups of participants in the long-run, pointing to a significant group of people leaving the labour force (see the detailed statistics at the end of Table A.1 in Appendix A).

Figure 3: Employment and unemployment rates by participation status

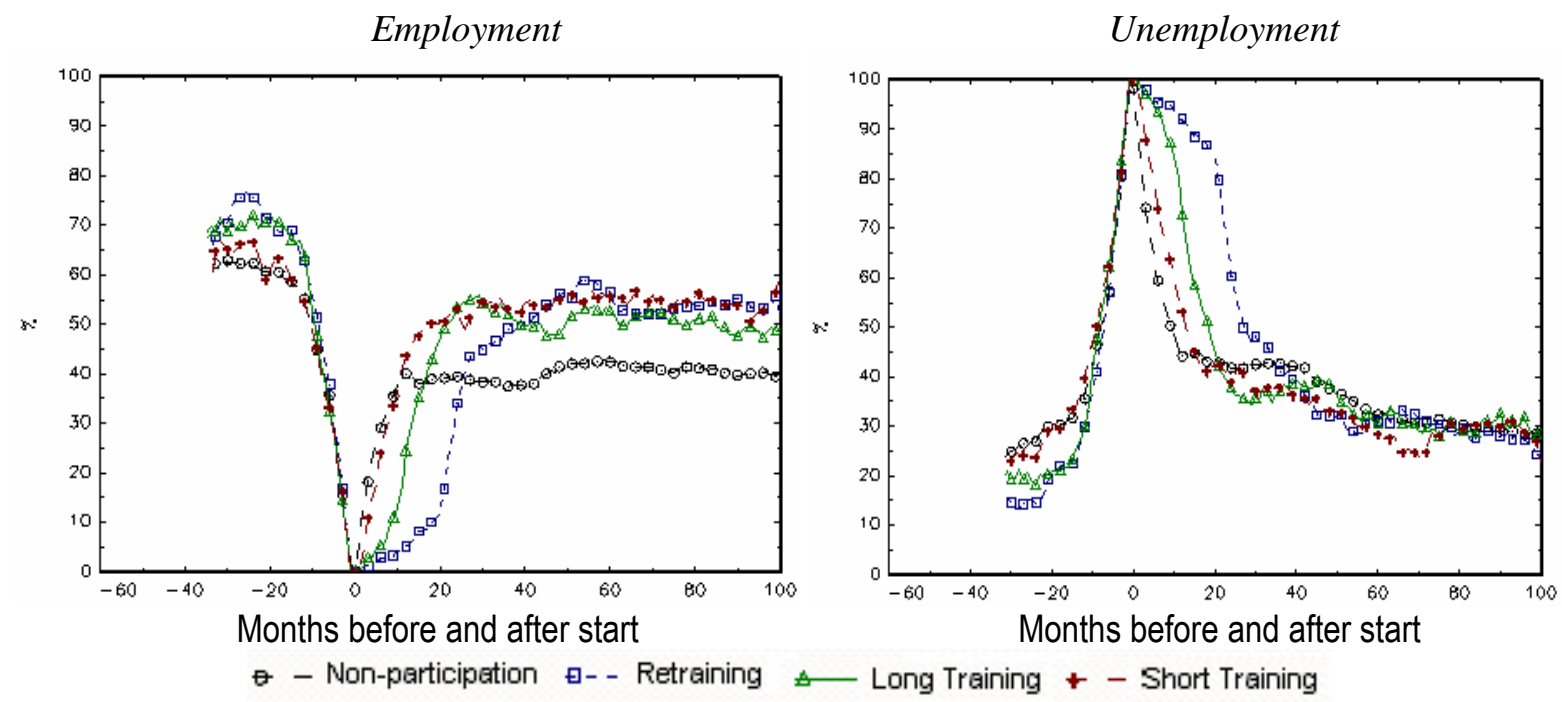

Note: The employment and unemployment information is given only up to 36 months prior to training. Due to the process of gathering administrative data after unification, many unemployed may be observed for shorter periods.

\section{$4 \quad$ Identification and estimation}

\subsection{Conditional independence and matching}

We base our analysis on the 'multiple treatments' model of the microeconometric evaluation literature: An individual chooses between several states like participation in a specific training programme or nonparticipation in such a programme. The different states are called 
treatments in the econometric evaluation literature. The potential participant in a programme gets a hypothetical outcome $\left\{Y^{0}, \ldots, Y^{M}\right\}$, e.g. employment, in each state $S \in\{0, \ldots, M\}$. This notation allows, us under the usual assumptions (see Rubin, 1974), to define our parameters of interest - the average treatment effects on the treated (ATETs) for pair-wise comparisons of the effects of different states (Lechner, 2001, 2002a, b):

$\theta_{0}^{m, l}:=E\left(Y^{m}-Y^{l} \mid S=m\right)=E\left(Y^{m} \mid S=m\right)-E\left(Y^{l} \mid S=m\right) ; \quad m \neq l ; m, l \in\{0, \ldots, M\}$

ATET $\left(\theta_{0}^{m, l}\right)$ is the expected effect for an individual that is drawn randomly from the population of participants in treatment $m$ only. Without further assumptions, ATETs are not identified from the data. But if we can observe all factors that jointly influence outcomes and the participation decision, then - conditional on these factors (call them $X$ ) - the participation decision and the outcomes are independent. This property is exploited by the conditional independence assumption (CIA).

\subsection{Is the conditional independence assumption plausible with our data?}

Plausibility of the CIA requires that all major factors that jointly determine participation and outcomes are observed in the data. Thus, we should identify these variables and show that they are available in our data. This requires an understanding of the underlying participation decisions. Selection into programmes is determined by three main factors that are discussed in turn: eligibility, selection by caseworkers and self-selection by potential participants.

In Germany, eligibility requires that the potential participant qualifies for or receives unemployment insurance payments. Moreover, he must have a professional degree from the German apprenticeship or higher education system, or a minimum amount of work experience in one field of profession. We control for these factors by use of the education variables, the individual employment records and the entries from the benefit payment register. 
Usually, it is the caseworker but it may also be the unemployed himself who proposes participation in training to improve employment prospects. In any case, the unemployed must apply before the beginning of the programme. The caseworker decides whether he will be admitted or not. There is no legal entitlement to participation, and caseworkers have a considerable amount of discretion. Usually, the caseworker decides in consultation with the potential participant whether or not and if so, what kind of training programme would be appropriate based on an assessment of the employment prospects and the specific qualification needs of the unemployed. According to German legislation, caseworkers have to take into account the chances of the unemployed for completing a specific programme successfully, and the situation in the local labour market. Variables capturing information about employment prospects and chances for successful completion of a programme include age, educational attainment, family status and past employment histories including information about past employers, earnings, position in job, specific occupation and industry. Moreover, our data contain detailed regional information that allow us to control for local labour market conditions, like the industrial, employment, population and wealth composition of the region as well as migration streams, tax revenues and local unemployment rates. In addition, since unemployment is rapidly rising during 1993 and 1994 and participation shows a varying pattern, we condition on the month of the start of the programmes thus netting out seasonal and timing effects.

From the point of view of the unemployed, his decision whether or not to participate in a programme is guided by considerations very similar to those of the caseworker. There are, however, additional reasons for joining or not joining a programme. If, for example, the unemployed sees no chance to find a job anyway, with or without a programme, he may prefer not to join a programme that reduces his leisure time (an important issue in the rapidly contracting East German economy). This again requires controlling for all factors that determine individual employment prospects and labour market conditions. Moreover, legislation provides rather strong incentives to participate in government-supported training. On the one hand, 
unemployed who refuse to participate in a training course, risk suspension of their unemployment benefits. On the other hand, periods during which unemployed receive transfer payments while participating in a training programme count towards acquisition of unemployment benefit claims. Therefore, we constructed variables from the (un)employment histories that indicate the UB claim at the beginning and at the end of a spell.

Although this is much more information than usually available in studies that rely on the CIA (e.g. Heckman and Smith, 1999; Brodaty, Crépon and Fougère, 2001; Larsson, 2003; Dorsett, 2005), there are some potentially important factors missing. In contrast to Gerfin and Lechner (2002) or Sianesi (2004), there is no information about the caseworker's direct assessment of the characteristics and prospects of the unemployed, for example with respect to motivation and ability. Moreover, we do not observe things like jail and health histories. For these variables, we have to rely on their indirect effects, i.e. on their effects on the employment and earnings history that materialised in the past. The fact that we do not observe pre-unification employment histories should not lead to additional unobserved heterogeneity because in the German Democratic Republic, unemployment was (officially) absent and labour force participation was very high. In addition, unification per se certainly discounted the value of human capital and experience obtained under the old centrally planned economic system. Thus, what is important is what happened during the rapid transition period directly after unification. Although we do not fully observe this period due to the phasing in of the data, we capture the most important parts of it by the choice of our evaluation sample and period.

\subsection{A note on estimation}

Having established identification of the effects, i.e. the general feasibility of consistent estimation of the effects, the question of the appropriate estimator arises. All possible parametric, semi- and nonparametric estimators are implicitly or explicitly built on the principle that for every comparison of two programmes, for every participant of one of those programmes we 
need a comparison observation from the other programme with the same characteristics regarding all factors that jointly influence selection and outcomes (see Section 4.2 for these variables). Here, we use propensity score matching estimators for multiple treatments as our baseline estimator to produce such comparisons. A clear advantage of these estimators is that they are essentially nonparametric and that they allow arbitrary individual effect heterogeneity (see Heckman, LaLonde and Smith, 1999, for matching with a binary treatment, and Imbens, 2000, and Lechner, 2001, for multiple treatments; Imbens, 2004, provides an excellent survey of the recent advances in this field). Gerfin and Lechner (2002) and Larsson (2003) used this estimator, among many others.

Appendix B contains the detailed results of a multivariate analysis that models selection into the different groups based on a multinomial probit model that is estimated by simulated maximum likelihood. Beyond providing useful descriptive statistics, the output from this selection model plays a key role in our selection correction mechanism since we use the estimated conditional on $\mathrm{X}$ choice probabilities (the so-called propensity scores) to form our comparison groups. The analysis revealed that gender, age, education, and last occupation are important individual characteristics that determine participation. Furthermore, although observed employment and unemployment histories are short, they are significantly correlated with participation choice. Regional information, such as the industrial, employment, population and wealth composition of the region as well as migration streams and tax revenues, which entered the probit in a highly disaggregated way to capture the specifics of supply and demand in the local labour market, play important roles in the selection process.

In addition to the propensity scores, we include as matching variables gender and the date of the beginning of the programme as well as three dummies which indicate whether the participant is observed employed 12, 24 and 36 months before the programme to make sure that we match correctly on these important variables. However, excluding all additional 
matching variables except gender, or adding elapsed unemployment duration before the programme does not change the qualitative results that we obtain for the effects of training (see Section 5.4 and the internet appendix for details).

We improve the standard matching estimator for multiple treatments in two dimensions: To allow for higher precision when many 'good' comparison observations are available we incorporate the idea of calliper or radius matching (e.g. Dehejia and Wahba, 2002) into the standard algorithm. Furthermore, we increase the matching quality by exploiting the fact that appropriate weighted regressions that use the sampling weights from matching have the socalled double robustness property. This property implies that the estimator remains consistent if either the matching step is based on a correctly specified selection model, or the regression model is correctly specified (e.g. Rubin, 1979; Joffe, Ten Have, Feldman and Kimmel, 2004). Moreover, this procedure should reduce small sample as well as asymptotic bias of matching estimators (see Abadie and Imbens, 2006) and thus increase robustness of the estimator.

The actual matching protocol is presented in detail in Appendix C. All issues concerning the estimation and tests of its operational characteristics are contained in the internet appendix (see in particular Appendix IB for the implications of imposing common support, and match quality). Lechner, Miquel and Wunsch (2004) contains more technical information about the estimator that are omitted here for the sake of brevity. The most important sensitivity checks are also discussed in Section 5.4. In summary, our estimation results are not sensitive to issues concerning the implementation of the estimator.

\section{$5 \quad$ The effects of training}

\subsection{Measurement of the labour market outcomes}

According to German legislation, the most important objectives of ALMP are to increase reemployment chances and to reduce the probability of remaining unemployed. Therefore, our 
outcome variables relate to the employment status, like registered unemployment and different types of employment (for example requiring a certain quality of the job, approximated by the job's duration or by the earnings compared to the previous job). Registered unemployment is defined as receipt of some form of benefits from the PES or participation in a training programme. We also consider gross earnings which is a crude measure for individual productivity. Below, we only present the results for those outcome variables that are most interesting. For all the others, the reader may consult the internet appendix which contains all background material.

Effects are measured monthly based on process time: Month 1 in process time is the month after the programme started (with simulated start dates for nonparticipants). Focusing on the beginning instead of the end rules out that programmes appear to be successful just because they keep their participants busy by making them stay in the programme. We consider a programme to have a positive effect (in the short run) if everybody would leave for 'good' employment immediately after starting participation.

As noted earlier, our employment related outcome variables have the problem that we cannot distinguish subsidised and unsubsidised employment before the year 2000. Beginning in 2000, this becomes possible, although for 2000 and 2001 there is some underreporting. Since in East Germany subsidised jobs were used on a large scale in the early and mid 1990s, all results presented below that relate to this period have to be interpreted with that caveat in mind. Nevertheless, we do have a clean measure of the long-run effects in Tables 6-8.

\subsection{Mean effects of the programmes for their participants}

Table 6 shows the mean outcomes (ATETs) for all comparisons. We concentrate on the effects eight years after participation started and the three outcome variables unsubsidised employment, unemployment and earnings. Compared to nonparticipation and using unsubsidised employment as outcome variable, we find that short training and retraining have sub- 
stantial positive effects on average, around a magnitude of a 10\%-point gain in employment. The effects of long training are not significantly different from zero, though. The estimators of the pairwise comparisons are subject to more sampling error due to the much smaller comparison samples, thus requiring a larger magnitude of the effect to become significant. Therefore, it is not surprising that - with few exceptions like the dominance of retraining compared to long training for participants in long training - the effects are hardly significant.

Table 6: Estimated effects on unsubsidised employment 8 years after programme start

\begin{tabular}{|c|c|c|c|c|c|c|}
\hline \multirow{2}{*}{ State $\mathrm{m}$} & \multirow{2}{*}{ State I } & \multicolumn{2}{|c|}{ Sample size } & \multirow{2}{*}{$\begin{array}{l}\text { Unsubsidised } \\
\text { employment }\end{array}$} & \multirow{2}{*}{ Unemployment } & \multirow{2}{*}{ Earnings } \\
\hline & & $\mathrm{m}$ & I & & & \\
\hline \multirow{3}{*}{$\begin{array}{l}\text { Short training } \\
\text { Long training } \\
\text { Retraining }\end{array}$} & nonparticipation & 292 & 3542 & $13.0^{*}$ & 3.3 & 208* \\
\hline & nonparticipation & 502 & 3542 & 3.8 & 6.8 & 145 \\
\hline & nonparticipation & 429 & 3542 & 7.3 & -0.1 & 101 \\
\hline \multirow{2}{*}{$\begin{array}{l}\text { Short training } \\
\text { Short training }\end{array}$} & long training & 292 & 502 & 4.3 & -2.8 & 55 \\
\hline & retraining & 292 & 429 & -5.2 & 0.6 & -75 \\
\hline \multirow{2}{*}{$\begin{array}{l}\text { Long training } \\
\text { Long training }\end{array}$} & short training & 502 & 292 & 3.2 & 3.8 & -20 \\
\hline & retraining & 502 & 429 & $-14.7^{*}$ & 9.8 & -102 \\
\hline \multirow{2}{*}{$\begin{array}{l}\text { Retraining } \\
\text { Retraining }\end{array}$} & short training & 429 & 292 & 8.4 & 1.5 & 120 \\
\hline & long training & 429 & 502 & -6.1 & -5.2 & -32 \\
\hline \multicolumn{2}{|l|}{ Note: $\quad$ Bolc } & & & . & & \\
\hline
\end{tabular}

The following figures show how the effects evolve over time. Figure 4 displays the estimates of the employment and unemployment effects of the different programmes (compared to all other states) for participants in the respective programme (ATETs). A line above zero indicates that the programme has a positive effect relative to the one (or nonparticipation) associated with that particular line. In other words, a line above zero is good news for the programme appearing in the header of the respective graph and bad news for the one associated with a particular line. Only effects significant at the $5 \%$ level are displayed. To use a consistent definition of employment over time, in these figures employment comprises both subsidised and unsubsidised employment. The difference between these two types is very small for about the last twenty months, but could be important for the short- and medium-run results given the number of employees in subsidised employment (see Section 2.1). 
Figure 4: Dynamics of the effects after programme start (ATET; differences in \%-points)
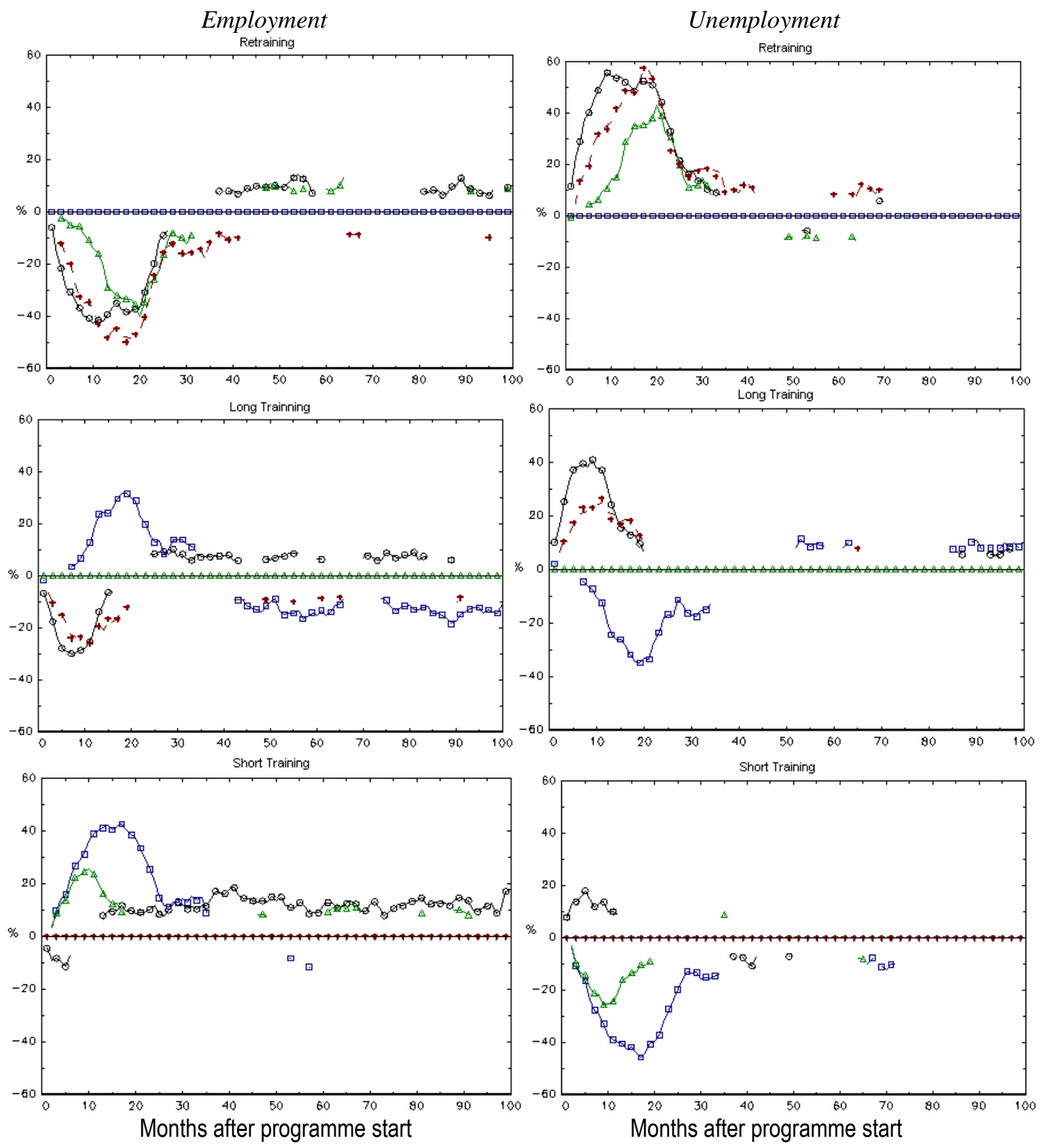

* - Non-participation $\boxminus--$ Retraining

$\star$ Long Training + - Short Training

Note: Only effects that are significant at the $5 \%$ level (point wise) appear in the figures.

The results for long training and retraining show negative short-run effects that are the larger the longer the programme. However, since we are not able to distinguish subsidised and unsubsidised employment in the short run, the lock-in effects that are present in all figures may be just because nonparticipants and participants in short training move to employment pro- 
grammes afterwards. ${ }^{13}$ In the longer run and with respect to employment, Figure 4 confirms the results of Table 6 in that retraining and short training dominate nonparticipation on average. Long training seems to have positive effects as well, although they are not significant at the end of the observation window. Yet, participants in long training would have benefited more had they participated in retraining instead. The effects with respect to unemployment are all zero in the long run (as suggested by Figure 3). This is probably related to the fact that training increases the period of receipt of unemployment benefits and/or that after remaining unemployed for such a long time, discouraged nonparticipants leave the labour force.

Figure 5: Dynamics of the effects monthly earnings (ATET; differences in EUR)
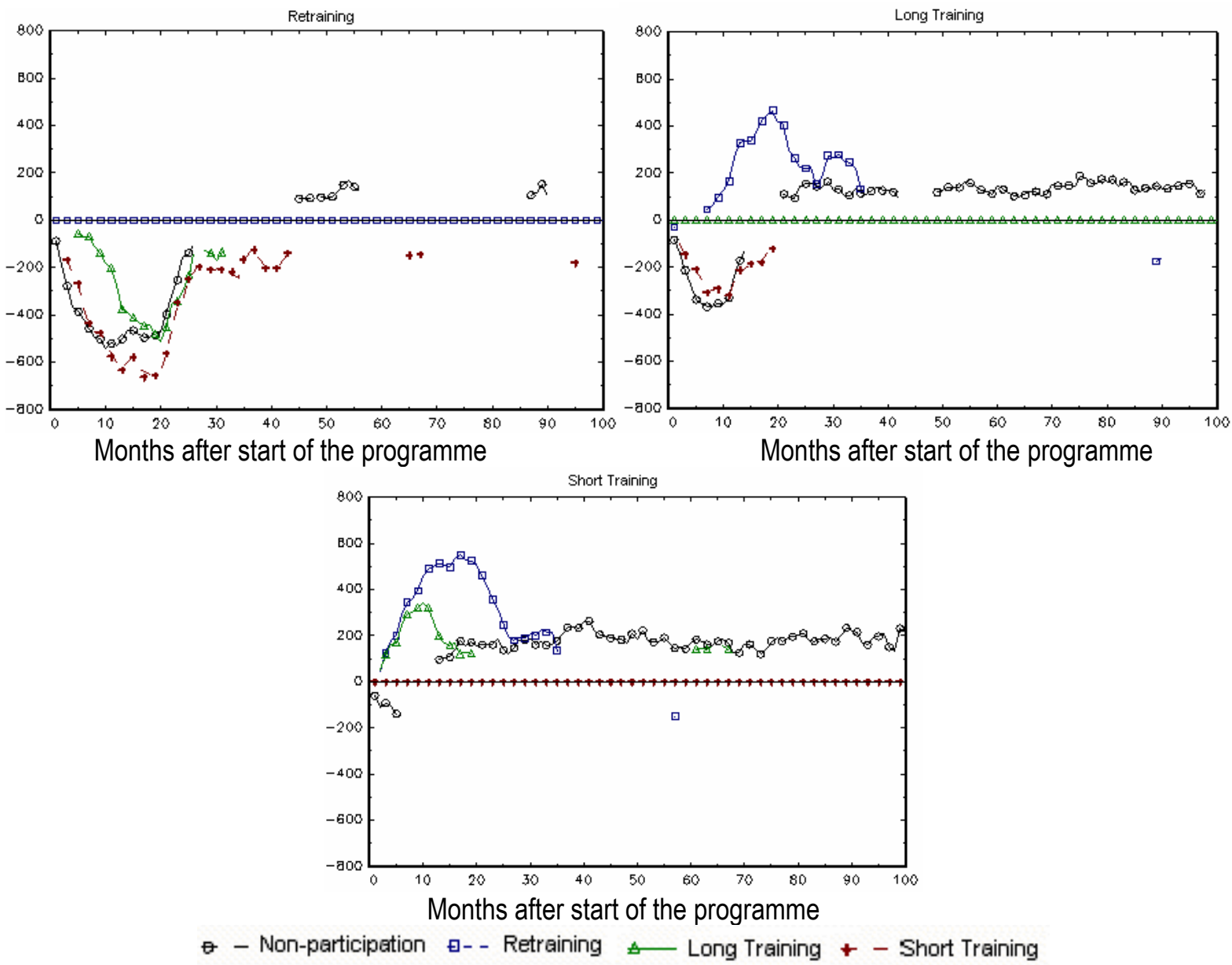

Note: $\quad$ Only effects that are significant at the $5 \%$ level (point wise) appear in the figures.

${ }^{13}$ Because of this ambiguity, we do not present cumulated effects as we did for West Germany in Lechner, Miquel and Wunsch (2004). 
The results in Figure 5 suggest that training consistently increases monthly earnings by about 100-200 EUR in the longer run for all training programmes (see also Table 6), although the results are not always significant for retrainees.

To check whether jobs are (somewhat) stable, we use an outcome variable which requires at least seven months of continuous employment (six months is the usual probation period in Germany, within which termination of a job is very easy for both sides). We obtain comparable results. The results are confirmed as well when we use employment that pays at least $90 \%$ of the job held prior to training (the results are available in the internet appendix).

\subsection{Heterogeneity by types of unemployed}

So far, we considered the average effects for the participants in the different programmes. Since participants are heterogeneous, there may be differences in how the programmes affect different types of individuals. Therefore, we stratify the sample along the dimensions unemployment duration, type of region, type of occupation and gender, and match within the strata. Note that the scope of this exercise is limited by the size of the subsamples. We find significant differences of the effects for the regional unemployment rate, the type of occupation before training, and gender (see Tables 7 and 8). The overall positive effect of short training is driven by its high effectiveness in regions with a comparatively low unemployment rate, whereas in the other regions it seems to be ineffective. Furthermore, the subsample results for different types of occupations suggest that short training may be the most effective programme for skilled workers. However, the samples underlying these estimates may be too small to draw robust inferences. 
Table 7: Heterogeneity of the effects on unsubsidised employment eight years after the beginning of

the programme (ATET; difference in \%-points)

\begin{tabular}{|c|c|c|c|c|c|}
\hline & \multicolumn{2}{|c|}{ Regional UE rate } & \multicolumn{3}{|c|}{ Type of occupationa } \\
\hline$m-1$ & $\leq 15 \%$ & $>15 \%$ & Unskilled & Skilledb & Salaried \\
\hline Short training - nonparticipation & $29.7^{*}$ & 3.2 & 7.1 & $20.1^{*}$ & 8.6 \\
\hline Short training - long training & 17.4 & 2.3 & -14.9 & $26.7^{*}$ & -3.3 \\
\hline Short training - retraining & 9.6 & -10.9 & -20.6 & 7.7 & -28.0 \\
\hline Long training - nonparticipation & 6.3 & 1.9 & 3.4 & -4.3 & 2.6 \\
\hline Long training - short training & $-23.5^{*}$ & 8.5 & 5.4 & $-25.2^{*}$ & -4.5 \\
\hline Long training - retraining & -16.8 & -15.3 & -13.6 & -3.1 & -20.6 \\
\hline Retraining - nonparticipation & 6.8 & 3.7 & -1.6 & 6.1 & 17.4 \\
\hline Retraining - short training & $-24.5^{*}$ & 0.8 & 0.5 & $-24.8^{*}$ & 1.8 \\
\hline \multirow[t]{2}{*}{ Retraining - long training } & 0.8 & 10.6 & 7.9 & 23.8 & 1.2 \\
\hline & \multicolumn{5}{|c|}{ Sample size } \\
\hline Nonparticipation & 1156 & 2232 & $680^{-1}$ & 810 & 946 \\
\hline Short training & 91 & 187 & 55 & 68 & 80 \\
\hline Long training & 174 & 309 & 58 & 74 & 263 \\
\hline Retraining & 136 & 279 & 101 & 166 & 88 \\
\hline
\end{tabular}

Note: $\quad$ Bold numbers indicate significance at the $5 \%$ level, numbers in italics at the $10 \%$ level and ${ }^{*}$ at the $1 \%$ level. Cells shaded in grey indicate that the difference of the two estimated effects is significant at the $5 \%$ level. aFor the comparison short training - retraining, only the pairwise differences unskilled-skilled and skilled-salaried are significant. bIncl. master craftsman. MNP estimates from the joint model, but the remaining steps of the estimation are performed in the subsamples. The number of observations does not add up to the one in the full sample because the common support criterion must delete more observations if used in subsamples (see the internet appendix).

Clearly, the most substantial differences occur with respect to gender and the two longer training programmes (see Table 8). Compared to nonparticipation, retraining increases the employment rate of participating women by about 25\%-points. It decreases unemployment by about 8\%-points and increases monthly earnings by about 400 EUR. Retraining is, however, completely ineffective for participating men. The effects of long training exhibit gender differences, too. The negative effects for month 96 indicate that participating in long training really hurts men by reducing their employment probabilities and increasing their unemployment probabilities. But this month is really an exception. For almost all other months, a zero effect for long training compared to nonparticipation cannot be rejected by the data and the male-female difference is smaller than for retraining. Short training courses appear to be effective for both men and women. 
Table 8: Effects 8 years after the beginning of the programme according to gender (ATET; difference in \%-points and differences in EUR)

\begin{tabular}{|c|c|c|c|c|c|c|c|c|c|c|c|}
\hline \multirow[t]{2}{*}{ Treated } & \multicolumn{2}{|c|}{ Obs. } & \multirow[t]{2}{*}{$\begin{array}{l}\text { Com- } \\
\text { parison }\end{array}$} & \multicolumn{2}{|c|}{ Obs. } & \multicolumn{2}{|c|}{$\begin{array}{c}\text { Unsubsidised } \\
\text { employment }\end{array}$} & \multicolumn{2}{|c|}{ Unemployment } & \multicolumn{2}{|c|}{ Earnings } \\
\hline & $M$ & W & & M & W & $\mathrm{M}$ & W & $M$ & W & $M$ & W \\
\hline Short training & 98 & 160 & nonpart. & 1252 & 1888 & $20.7^{*}$ & 11.7 & $\begin{array}{l}-9.2 \\
\end{array}$ & 2.6 & $355^{*}$ & 190 \\
\hline Long training & 159 & 292 & nonpart. & & & -11.2 & $11.0^{*}$ & $16.7^{*}$ & 1.7 & -96 & $228^{*}$ \\
\hline Retraining & 232 & 161 & nonpart. & & & 0.8 & $25.5^{*}$ & 2.3 & -8.3 & 4 & $386^{*}$ \\
\hline Short training & 98 & 160 & long train. & 159 & 292 & 13.7 & -2.8 & -11.1 & 4.2 & 142 & -79 \\
\hline Short training & & & retraining & 232 & 161 & -0.8 & -17.5 & 0.1 & 3.5 & -84 & -275 \\
\hline Long training & 159 & 292 & retraining & & & 1.5 & $-19.5^{*}$ & 12.4 & 8.4 & 227 & -199 \\
\hline Long training & & & short train. & 98 & 160 & 0.7 & 3.2 & 7.2 & -9 & 16 & 136 \\
\hline Retraining & 232 & 161 & short train. & & & -11.1 & 13.7 & 5.6 & $-23.3^{k}$ & -154 & 198 \\
\hline Retraining & & & long train. & 159 & 292 & 7.9 & 3.4 & -5.7 & -10.9 & 80 & -16 \\
\hline
\end{tabular}

Note: Bold numbers indicate significance at the $5 \%$ level, numbers in italics relate to the $10 \%$ level and * to the $1 \%$ level. Cells shaded in grey indicate that the difference of the two estimated effects is significant at the $5 \%$ level. M: Men, W: Women. Results are based on estimates in the different subsamples (including the MNP estimation) for men and women. Since the effects for men and women based on the common estimation of the MNP model show considerable effect heterogeneity, it appears to be possible that more flexibility is required when estimating the decision to participate in a programme. Therefore, we estimate MNP's for men and women separately, but we do not find significant differences in the effects compared to the case with a common MNP model.

The reason for these stark gender differences appears to be different types of training obtained by women and men. Table 9 shows the shares in the original professions (before training) and the profession a course is planned to qualify for (target profession) for our sample of training participants, for men (upper panel) and women (lower panel) and the different types of training. The last two columns state the profession-specific unemployment rates in 1994 and 2002. In general, we see that men in the metal production/processing and mechanics sector are much more likely to receive either short training or retraining, whereas long training is somewhat concentrated among technical professions. For women, long and short training is concentrated in office related occupations. Female retrainees are more evenly spread across occupations. Comparing original and target professions for short training, not many differences appear, which is in line with the aims of these programmes. For men in long training, some professions decline (agriculture, mining, forestry; metal related occupations; technical professions; health and social services; education related professions), but construction as well as office related professions increase. For women in long training we see a considerable increase in office related occupations, and a decrease everywhere else. 
Table 9: Original and target professions by programme group in 1993-1994

\begin{tabular}{|c|c|c|c|c|c|c|c|c|}
\hline \multirow{3}{*}{ Profession } & \multicolumn{2}{|c|}{ Short training } & \multicolumn{2}{|c|}{ Long training } & \multicolumn{2}{|c|}{ Retraining } & \multicolumn{2}{|c|}{ UE rate } \\
\hline & Original & Target & Origina & Target & Original & Target & 1994 & 2002 \\
\hline & \multicolumn{6}{|c|}{ Men } & & \\
\hline No formal professional degree & 13 & - & 8 & - & 14 & - & & \\
\hline No information & - & 22 & - & 4 & - & 4 & & \\
\hline Agriculture, gardening, forestry, mining & 8 & 3 & 5 & 2 & 10 & 2 & 24 & 31 \\
\hline Metal production/processing, mechanics & 37 & 26 & 17 & 9 & 34 & 2 & 15 & 19 \\
\hline Textile/leather manufacturing & 3 & - & 1 & 1 & 2 & - & 59 & 42 \\
\hline Food and nuitrition & 1 & - & 2 & 2 & 3 & 1 & 33 & 30 \\
\hline Construction & 6 & 12 & 4 & 12 & 6 & 18 & 6 & 33 \\
\hline Construction related handcraft & 12 & 12 & 8 & 13 & 5 & 53 & 9 & 28 \\
\hline Technical profession, other manufacturing & 12 & 11 & 27 & 23 & 15 & 4 & 16 & 19 \\
\hline Office work & 2 & 3 & 6 & 25 & 1 & 7 & 16 & 20 \\
\hline Health/social services, education & 3 & 2 & 7 & 2 & 2 & 3 & 9 & 9 \\
\hline Other services & 5 & 11 & 6 & 8 & 10 & 7 & 22 & 28 \\
\hline Correlation(\% target - \% origin, UE rate 1994) & \multicolumn{2}{|c|}{-0.21} & \multicolumn{2}{|c|}{-0.15} & \multicolumn{2}{|c|}{-0.24} & & \\
\hline \multirow[t]{2}{*}{ Correlation( $\%$ target - $\%$ origin, UE rate 2002 ) } & \multicolumn{2}{|c|}{0.15} & \multicolumn{2}{|c|}{0.15} & \multirow{2}{*}{\multicolumn{2}{|c|}{0.18}} & & \\
\hline & \multicolumn{4}{|c|}{ Women } & & & & \\
\hline No formal professional degree & 12 & - & 3 & - & 7 & - & & \\
\hline No information & 1 & 34 & 1 & 9 & - & 8 & & \\
\hline Agriculture, gardening, forestry, mining & 5 & 2 & 6 & 3 & 12 & 9 & 24 & 31 \\
\hline Metal production/processing, mechanics & 4 & 1 & 1 & 0 & 5 & 1 & 15 & 19 \\
\hline Textile/leather manufacturing & 8 & 2 & 5 & 0 & 16 & - & 59 & 42 \\
\hline Food and nutrition & 5 & 3 & 6 & 3 & 3 & 4 & 33 & 30 \\
\hline Construction & - & - & $<1$ & 1 & - & - & 6 & 33 \\
\hline Construction related handcraft & 2 & 1 & 2 & 0 & 3 & 5 & 9 & 28 \\
\hline Technical profession, other manufacturing & 13 & 2 & 15 & 6 & 12 & 5 & 16 & 19 \\
\hline Office work & 36 & 42 & 42 & 65 & 16 & 36 & 16 & 20 \\
\hline Health/social services, education & 6 & 6 & 13 & 6 & 13 & 18 & 9 & 9 \\
\hline Other services & 10 & 7 & 7 & 6 & 12 & 14 & 22 & 28 \\
\hline Correlation(\% target - \% origin, UE rate 1994) & \multicolumn{2}{|c|}{-0.34} & \multicolumn{2}{|c|}{-0.15} & \multicolumn{2}{|c|}{-0.56} & & \\
\hline Correlation(\% target - \% origin, UE rate 2002) & \multicolumn{2}{|c|}{-0.19} & \multicolumn{2}{|c|}{-0.09} & \multicolumn{2}{|c|}{-0.51} & & \\
\hline Overall UE rate & & & & & & & 15 & 22 \\
\hline
\end{tabular}

Source: Own calculations on the basis of our evaluation sample. UE rates: BA (1992-2004).

Note: $\quad$ Entries in \%. UE rate: number of unemployed in the respective profession as a percentage of the sum of socially insured employees and registered unemployed in 1996/2002.

The most interesting case is clearly retraining. For about $71 \%$ of the unemployed male the target profession of retraining was construction related (in particular craft related professions), whereas this share was only 5\% for women. The male share of this type of occupation among original professions was only $11 \% \cdot{ }^{14}$ About one third of the women had some office related target profession, about another $20 \%$ were directed towards health, social and education re-

\footnotetext{
${ }^{14}$ The inflow into construction comes from all occupations with the exception of the group health/social services, education (see Table IA.1 in the internet appendix).
} 
lated professions. These choices of target professions by the caseworkers and the unemployed may have been rational in the years 1993 and 1994 when the major destinations for male and female unemployed showed average or below average unemployment rates. This is confirmed in Table 9 by the correlations between the difference in the shares in target and original profession and the unemployment rates, which are negative for all types of training and both men and women in 1994. However, as indicated by a positive correlation in 2002, the long-run prediction for men turned out to be very bad, because of the bust in the construction sector in the second half of the 1990s - just at the time most of the retrainees completed their programme. In 2002, the unemployment rates in the construction related professions were around $30 \%$ compared to an already high East German average of about 22\%. In contrast, women were luckier. The unemployment rates in their main target professions were still below average in 2002, and the respective correlation is negative.

Significant gender differences in programme effects have been found in several other evaluation studies that analyse ALMPs, see e.g. Puhani (1999); Kluve, Lehmann and Schmidt (1999, 2004) for Poland as well as the surveys by Friedlander, Greenberg and Robins (1997); Heckman, LaLonde and Smith (1999) for Western market economies. Rather than indicating that a programme has different effects for men and women, our findings suggest that these differences may occur because women in fact attend different programmes than men.

\subsection{Sensitivity analysis}

We performed several sensitivity tests to check the robustness of our results to implementation issues. We only present a summary of the results and refer the interested reader to the internet appendix for any details.

We checked whether our sample selection and matching algorithm succeeds in balancing participants' and non-participants' elapsed unemployment duration before the actual or simulated programme start. On the one hand, we used a different procedure for simulating programme 
start dates for nonparticipants. We randomly draw from the empirical distribution of elapsed unemployment durations before programme start of participants and check whether the respective nonparticipant has at least the same unemployment duration. If so, we assign as hypothetical starting date the month after the drawn unemployment duration. ${ }^{15}$ Our results are almost unchanged by this new procedure. On the other hand, we include the elapsed UE duration before programme start as additional matching variable to make sure that we match correctly on that variable. Again, our results remain largely unaffected.

In addition, the common support criterion is tightened by defining the upper and lower bounds as the $10^{\text {th }}$ largest and smallest observation instead of the minimum or maximum. This leads to a better match in the tails of the propensity score distribution. Although a considerable number of observations is dropped, the effects hardly change in magnitude, though there is some change in significance levels. Nevertheless, the overall conclusions do not change.

Moreover, the additional matching variables other than gender that are included in the definition of the distance metric in the matching algorithm are not used. The results are qualitatively identical, but in particular for retraining, the effects are somewhat smaller and fewer of them are significant.

The fourth test concerned smoothing the estimated effects by computing three-month moving averages of the respective outcome variables, thus increasing precision. The efficiency gains are very small.

Finally, the region Berlin could be a special case because it combines East Berlin (former capital of the GDR) with West Berlin, which experienced the West German economic system even before unification. Therefore, we rerun all estimations excluding all inhabitants of Berlin (the distinction between East and West Berlin before unification is not possible with our data). Again, the results are qualitatively identical.

\footnotetext{
${ }^{15}$ We thank Barbara Sianesi for suggesting this to us.
} 


\section{Conclusion}

We analyse the effects of government-sponsored training for the unemployed in the beginning of the transition process in East Germany. Our analysis is based on new, large and very informative administrative data that allow us to control for potential selection bias, to use robust nonparametric matching estimators in a multiple treatment framework, to account for treatment effect heterogeneity with respect to both programmes and participants, and to observe interesting labour market outcomes over eight years after programme start.

Generally, training increases long-term employment prospects and earnings, but does not change registered unemployment. The positive long-run effects need some years to materialise because for all programmes there are initial negative (lock-in) effects. The magnitude of the lock-in effects is related to programme duration.

This general finding is however not at all true for men who participate in long training or retraining. At least part of the explanation for these negative results is that caseworkers in East Germany severely misjudged the future demand for skills for men. They tended to retrain many of the male unemployed towards occupations in the construction sector (about $70 \%$ of the participants in retraining) that experienced a boom during those years. Unfortunately, soon after the courses were completed, the boom went into a bust and the blessings of having obtained funding for long vocational training became a curse for its participants.

A caveat of our analyses is that we are not able to perform a cost-benefit analysis because of the unavailability of cost data both on the individual level and aggregated for each type of training. As another caveat, prior to the year 2000 it is impossible in our data to distinguish between subsidised employment, for example in an employment programme, and unsubsidised employment in the first labour market. This needs to be taken into account when interpreting the effects during the first six to seven years after programme start. However, since for 2002 this data is available, our long-term findings are not subject to this problem. 


\section{References}

Abadie, A. and G. W. Imbens (2006): "Large Sample Properties of Matching Estimators for Average Treatment Effects", Econometrica, 74(1), 235-267.

Akerlof, G., A. Rose, J. Yellen and H. Hessenius (1991): "East Germany in from the Cold: The Economic Aftermath of Currency Union", Brookings Papers on Economic Activity, 1991(1), 1-105.

Ashenfelter, O. (1978): "Estimating the Effect of Training Programs on Earnings", Review of Economics and Statistics, 6(1), 47-57.

Bender, S., A. Bergemann, B. Fitzenberger, M. Lechner, R. Miquel, S. Speckesser, and C. Wunsch (2005): "Die Wirksamkeit von FuU-Maßnahmen - Ein Evaluationsversuch mit prozessproduzierten Daten aus dem IAB", Beiträge zur Arbeitsmarkt- und Berufsforschung, 289, Nürnberg.

Bender, S., A. Haas and C. Klose (2000): "The IAB employment subsample 1975-1995", Schmollers Jahrbuch, Zeitschrift für Wirtschafts- und Sozialwissenschaften, 120/4, 649-662.

Bender, S., J. Hilzendegen, G. Rohwer and H. Rudolph (1996): "Die IAB-Beschäftigtenstichprobe 1975-1990", Beiträge zur Arbeitsmarkt- und Berufsforschung, 197.

Bergemann, A., B. Fitzenberger and S. Speckesser (2004): "Evaluating the Dynamic Employment Effects of Training Programs in East Germany Using Conditional Difference-in-Differences", ZEW Discussion Paper 04-41.

Brodaty T., B. Crépon and D. Fougère (2001): "Using Kernel Matching Estimators to Evaluate Alternative Youth Employment Programs: Evidence from France, 1986-1988", in M. Lechner and F. Pfeiffer (eds.): Econometric Evaluations of Labour Market Policies, Heidelberg: Physica Verlag, 85-124.

Bundesanstalt für Arbeit (BA, 1992-2004): "Arbeitsstatistik - Jahreszahlen", Amtliche Nachrichten der Bundesanstalt für Arbeit, 40-52, Special Issue, Nuremberg.

Couch, K.A. (1992): "New Evidence on the Long-Term Effects of Employment Training Programs", Journal of Labour Economics, 10(4), 380-388.

Dehejia, R. H. and S. Wahba (2002): "Propensity-Score-Matching Methods for Nonexperimental Causal Studies", Review of Economics and Statistics, 84, 151-161.

Dorsett, R. (2005): "The New Deal for Young People: Effect on the Labour Market Status of Young Men", Labour Economics, forthcoming.

Fitzenberger, B., and H. Prey (1998): "Beschäftigungs- und Verdienstwirkungen von Weiterbildungsmassnahmen im ostdeutschen Transformationsprozess: Eine Methodenkritik", in: F. Pfeiffer and W. Pohlmeier (eds.), Qualifikation, Weiterbildung und Arbeitsmarkterfolg, ZEW-Wirtschaftsanalysen, 31, pp. 39-95, Nomos, Baden-Baden.

Fitzenberger, B., and H. Prey (2000): "Evaluating Public Sector Sponsored Training in East Germany", Oxford Economic Papers, 52, 497-520.

Fitzenberger, B., and S. Speckesser (2005): "Employment Effects of the Provision of Specifc Professional Skills and Techniques in Germany", Goethe-University Frankfurt Main, Unpublished Manuscript.

Friedlander, D., D.H. Greenberg and P.K. Robins (1997): "Evaluating Government Training Programs for the Economically Disadvantaged", Journal of Economic Literature, 35(4), 1809-1855. 
Fredriksson, P. and P. Johansson (2003): "Program Evaluation and Random Program Starts", IFAU Discussion Paper, 2003(1), Uppsala.

Fredriksson, P. and P. Johansson (2004): "Dynamic Treatment Assignment - The Consequences for Evaluations Using Observational Data," IZA Discussion Paper 1062, Institute for the Study of Labor, Bonn.

Gerfin, M., and M. Lechner (2002): "Microeconometric Evaluation of the Active Labour Market Policy in Switzerland", The Economic Journal, 112, 854-893.

Heckman, J., R. LaLonde and J. Smith (1999): "The Economics and Econometrics of Active Labor Market Programs", in: O. Ashenfelter and D. Card (eds.), Handbook of Labour Economics, Vol. 3, 1865-2097, Amsterdam: North-Holland.

Heckman, J. and J. Smith (1999): "The Pre-Programme Earnings Dip and the Determinants of Participation in A Social Programme Implications For Simple Programme Evaluation Strategies", Economic Journal, 109, 1-37.

Hotz, J., G. Imbens and J. Klerman (2000): "The Long-Term Gains from GAIN: A Re-Analysis of the Impacts of the California GAIN Program", NBER Working Paper, 8007.

Hübler, O. (1997): "Evaluation beschäftigungspolitischer Massnahmen in Ostdeutschland", Jahrbücher für Nationalökonomie und Statistik, 216(1), 21-44.

Hübler, O. (1998): "Berufliche Weiterbildung und Umschulung in Ostdeutschland - Erfahrungen und Perspektiven", in: F. Pfeiffer and W. Pohlmeier (eds.), Qualifikation, Weiterbildung und Arbeitsmarkterfolg, ZEWWirtschaftsanalysen, 31, 97-132, Nomos, Baden-Baden.

Hujer, R. and M. Wellner (2000): "Berufliche Weiterbildung und individuelle Arbeitslosigkeitsdauer in Westund Ostdeutschland: Eine mikroökonometrische Analyse", Mitteilungen aus der Arbeitsmarkt- und Berufsforschung, 33, 405-420.

Hujer, R., S. Thomsen and C. Zeiss (2004): "The Effects of Vocational Training Programmes on the Duration of Unemployment in Eastern Germany", IZA Discussion Paper 1117.

Imbens, G. W. (2000): "The Role of the Propensity Score in Estimating Dose-Response Functions", Biometrika, 87, 706-710.

Imbens, G. W. (2004): "Nonparametric Estimation of Average Treatment Effects under Exogeneity: A Review", Review of Economics and Statistics, 86(1), 4-29.

Jacobson, L., R. LaLonde and D.G. Sullivan (2004): "Estimating the Returns to Community College Schooling for Displaced Workers", IZA Discussion Paper 1017.

Jespersen, S., J.R. Munch and L. Skipper (2004): "Costs and Benefits of Danish Active Labour Market Programmes", Danish Economic Council, Working Paper 2004:1.

Joffe, M. M., T. R. Ten Have, H. I. Feldman, and St. Kimmel (2004): "Model Selection, Confounder Control, and Marginal Structural Models", The American Statistician, November, 58-4, 272-279.

Kluve, J., H. Lehmann and C.M. Schmidt (1999): "Active Labor Market Policies in Poland: Human Capital Enhancement, Stigmatization, or Benefit Churning?“, Journal of Comparative Economics, 27, 61-89.

Kluve, J., H. Lehmann and C.M. Schmidt (2004): "Disentangling Treatment Effects of Labor Market Policies: The Role of Employment Histories", IZA, Unpublished Manuscript. 
Kraus, F., P. Puhani and V. Steiner (1999): "Employment Effects of Publicly Financed Training Programs - The East German Experience", Jahrbücher für Nationalökonomie und Statistik, 219, 216-248.

Larsson, L. (2003): "Evaluation of Swedish Youth Labor Market Programs", Journal of Human Resources 38(4).

Lechner, M. (1999): "Earnings and Employment Effects of Continuous Off-the-job Training in East Germany after Unification", Journal of Business Economics and Statistics, 17, 74-90.

Lechner, M. (2000): "An Evaluation of Public Sector Sponsored Continuous Vocational Training Programs in East Germany", Journal of Human Resources, 35, 347-375.

Lechner, M. (2001): "Identification and Estimation of Causal Effects of Multiple Treatments under the Conditional Independence Assumption", in: M. Lechner and F. Pfeiffer (eds.), Econometric Evaluation of Active Labour Market Policies, 43-58, Heidelberg: Physica.

Lechner, M. (2002a): "Programme Heterogeneity and Propensity Score Matching: An Application to the Evaluation of Active Labour Market Policies", Review of Economics and Statistics, 84, 205-220.

Lechner, M. (2002b): "Some Practical Issues in the Evaluation of Heterogeneous Labour Market Programmes by Matching Methods", Journal of the Royal Statistical Society - Series A, 165, 59-82.

Lechner, M. (2004): "Sequential Matching Estimation of Dynamic Causal Models", Discussion Paper 2004-06, Department of Economics, University of St. Gallen.

Lechner, M. and R. Miquel (2005): "Identification of Effects of Dynamic Treatments by Sequential Conditional Independence Assumptions", Discussion Paper 2005-17, Department of Economics, University of St. Gallen.

Lechner, M., R. Miquel and C. Wunsch (2004): "Long-run effects of Public Sector Sponsored Training in West Germany", Discussion Paper 2004-19, Department of Economics, University of St. Gallen.

Lubyova, M., and J.C. van Ours (1999): "Effects of Active Labour Market Programs on the Transition Rate from Unemployment into Regular Jobs in the Slovak Republic", Journal of Comparative Economics, 27, 90-112.

Martin, J. P., and D. Grubb (2001): "What Works and for Whom: A Review of OECD Countries' experiences with active labour market policies", Swedish Economic Policy Review, 8(2), 9-56.

Miquel, R., C. Wunsch and M. Lechner (2002): "Die FuU-Teilnehmer-Datei 1976-1997", Graues Papier des Instituts für Arbeitsmarkt- und Berufsforschung, Nuremberg.

OECD (1996a): "Lessons from Labour Market Policies in the Transition Countries", OECD, Paris.

OECD (1996b): "The Public Employment Service: Austria, Germany, Sweden", OECD, Paris.

O'Leary, C.J. (1998a): "Evaluating the Effectiveness of Active Labour Programmes in Hungary", Technical Report 98-13, W.E. Upjohn Institute for Employment Research, Kalamazoo, MI.

O'Leary, C.J. (1998b): "Evaluating the Effectiveness of Active Labour Programmes in Poland", Technical Report 98-12, W.E. Upjohn Institute for Employment Research, Kalamazoo, MI.

O'Leary, C.J., P. Kolodziejczyk and G. Lázár (1998): "The Net Impact of Active Labour Programmes in Hungary and Poland", International Labour Review, 137(3), 321-346.

Pannenberg, M. (1995): "Weiterbildungsaktivitäten und Erwerbsbiographie - Eine empirische Analyse für Deutschland", Frankfurt/New York: Campus. 
Pannenberg, M. and C. Helberger (1997): "Kurzfristige Auswirkungen staatlicher Qualifizierungsmassnahmen in Ostdeutschland: Das Beispiel Fortbildung und Umschulung", in: D. Timmermann (ed.), Bildung und Arbeit in Ostdeutschland, Schriften des Vereins für Sozialpolitik, 249, 77-97.

Prey, H. (1999), Wirkungen staatlicher Qualifizierungsmassnahmen - Eine empirische Untersuchung für die Bundesrepublik Deutschland, Bern/Stuttgart/Wien: Paul Haupt.

Puhani, P. (1996): "Poland on the Dole - Unemployment Benefits, Training, and Long-Term Unemployment during Transition", ZEW Discussion Paper 96-30, Mannheim.

Puhani, P. (1999): Evaluating Active Labour Market Policies - Empirical Evidence for Poland during Transition, ZEW Economic Studies 5, Heidelberg: Physica.

Puhani, P. and V. Steiner (1997): "The Effectiveness and Efficiency of Active Labour Market Programmes in Poland", Empirica, 24, 209-231.

Rubin, D. B. (1974): "Estimating Causal Effects of Treatments in Randomized and Nonrandomized Studies", Journal of Educational Psychology, 66, 688-701.

Rubin, D. B. (1979): "Using Multivariate Matched Sampling and Regression Adjustment to Control Bias in Observational Studies", Journal of the American Statistical Association, 74, 318-328.

Sianesi, B. (2004): "An evaluation of the Swedish system of active labour market programmes in the 1990s", Review of Economics and Statistics, 86(1), 133-155.

Speckesser, S. (2004): "Using Social Insurance Data for the Evaluation of Active Labour Market Policy: Employment Effects of Further Training for the Unemployed in Germany", University of Mannheim, Unpublished Manuscript.

Staat, M. (1997), Empirische Evaluation von Fortbildung und Umschulung, Schriftenreihe des ZEW, 21, BadenBaden: Nomos.

Steiger, H. (2004): "Is less more? A look at nonparticipation in Swiss active labour market programmes", University of St.Gallen, mimeo.

Van Ours, J. (2004): "The Locking-in Effect of Subsidized Jobs", Journal of Comparative Economics, 32, 37-52.

Winter-Ebmer, R. (2001): "Evaluating an Innovative Redundancy-Retraining Project: The Austrian Steel Foundation", IZA Discussion Paper 277.

Wunsch, C. (2005): "Labour Market Policy in Germany: Institutions, Instruments and Reforms since Unification", Discussion Paper 2005-6, Department of Economics, University of St. Gallen. 


\section{Appendix A: Data}

Table A.1: Descriptive statistics

\begin{tabular}{|c|c|c|c|c|c|c|}
\hline & $\begin{array}{c}\text { Non- } \\
\text { participation }\end{array}$ & $\begin{array}{c}\text { Short } \\
\text { training }\end{array}$ & $\begin{array}{l}\text { Long } \\
\text { training }\end{array}$ & Retraining & $\begin{array}{l}\text { Practice } \\
\text { firm }\end{array}$ & Other \\
\hline Number of observations & 4604 & 321 & 538 & 445 & 162 & 118 \\
\hline \multicolumn{7}{|c|}{ Proportions in \% } \\
\hline \multicolumn{7}{|c|}{ Personal characteristics } \\
\hline Women & 63 & 65 & 65 & 43 & 58 & 36 \\
\hline Older than 50 years & 8 & 7 & 6 & 1 & 9 & 1 \\
\hline Younger than 26 years & 12 & 12 & 9 & 23 & 12 & 19 \\
\hline $\mathrm{Age}^{*}$ & 36.82 & 36.18 & 37.62 & 31.64 & 37.16 & 34.17 \\
\hline Marital status: $\quad$ Single & 41 & 40 & 32 & 48 & 33 & 44 \\
\hline Married & 59 & 60 & 68 & 52 & 67 & 56 \\
\hline Children: No child & 40 & 35 & 32 & 40 & 43 & 41 \\
\hline At least one child & 60 & 65 & 68 & 60 & 57 & 59 \\
\hline \multicolumn{7}{|c|}{ Education } \\
\hline No professional degree & 12 & 7 & 4 & 14 & 8 & 5 \\
\hline With professional degree & 78 & 87 & 77 & 81 & 86 & 92 \\
\hline University degree, Polytechnical degree & 4 & 3 & 15 & 3 & 4 & 4 \\
\hline \multicolumn{7}{|c|}{ Position in last job } \\
\hline Salaried employee & 26 & 30 & 54 & 21 & 31 & 31 \\
\hline Part-time worker & 26 & 20 & 17 & 10 & 12 & 9 \\
\hline Master craftsman & 1 & 0 & 1 & 0 & 0 & 0 \\
\hline Unskilled worker & 22 & 25 & 13 & 28 & 23 & 14 \\
\hline Skilled worker & 26 & 26 & 16 & 40 & 34 & 45 \\
\hline \multicolumn{7}{|c|}{ Last occupation } \\
\hline \multicolumn{7}{|l|}{ Agriculture, forestry, fishing } \\
\hline $\begin{array}{l}\text { Plumbing, metal construction technology, tech- } \\
\text { nology, natural sciences, machinist, electronics } \\
\text { Food and nutrition, merchant (goods and ser- } \\
\text { vices), transportation, storage, administration, } \\
\text { office work, business and social sciences, health }\end{array}$ & 9 & 11 & 14 & 14 & 14 & 19 \\
\hline $\begin{array}{l}\text { services, hairdressing, guest assistance, house- } \\
\text { keeping, cleaning, security services, social ser- } \\
\text { vices, education, counselling, media, humanities, } \\
\text { arts, unskilled worker }\end{array}$ & 55 & 59 & 66 & 47 & 51 & 45 \\
\hline Construction, woodworking & 9 & 8 & 4 & 11 & 17 & 14 \\
\hline $\begin{array}{l}\text { Chemical worker, polymer processing, metal } \\
\text { production and processing, textile, leather, cloth- } \\
\text { ing, paper manufacture and processing, printing, } \\
\text { mining, stone, ceramics and glass making and/or } \\
\text { processing }\end{array}$ & 5 & 5 & 2 & 13 & 6 & 8 \\
\hline \multicolumn{7}{|c|}{ İndustrial sector } \\
\hline Construction & 8 & 6 & 5 & 8 & 9 & 11 \\
\hline $\begin{array}{l}\text { Commerce, banking, insurance, local and re- } \\
\text { gional authorities, social insurance, non-profit } \\
\text { organisations, private household, transportation, } \\
\text { telecommunications, other services }\end{array}$ & 58 & 64 & 60 & 54 & 59 & 42 \\
\hline Agriculture, forestry, fishing & 2 & 2 & 1 & 2 & 1 & 3 \\
\hline $\begin{array}{l}\text { Energy and supply industry, mining, manufactur- } \\
\text { ing (without construction) }\end{array}$ & 27 & 25 & 30 & 32 & 27 & 37 \\
\hline
\end{tabular}

Table A.1 to be continued 
Table: A.1: Descriptive statistics (continued-1)

\begin{tabular}{|c|c|c|c|c|c|c|}
\hline & $\begin{array}{c}\text { Non- } \\
\text { participation }\end{array}$ & $\begin{array}{l}\text { Short } \\
\text { training }\end{array}$ & $\begin{array}{l}\text { Long } \\
\text { training }\end{array}$ & Retraining & $\begin{array}{c}\text { Practice } \\
\text { firm }\end{array}$ & Other \\
\hline \multicolumn{7}{|c|}{ Last monthly earnings } \\
\hline Salary in Euros* & 947 & 1053 & 1204 & 1144 & 1137 & 1132 \\
\hline No information & 20 & 12 & 13 & 9 & 9 & 8 \\
\hline $1278>$ salary & 53 & 55 & 41 & 53 & 54 & 55 \\
\hline $1278 \leq$ salary $<2556$ & 25 & 33 & 42 & 39 & 35 & 36 \\
\hline $2556 \geq$ salary & 2 & 0 & 3 & 0 & 1 & 1 \\
\hline \multicolumn{7}{|c|}{ Remaining unemployment (UE) benefits claim at the end of the last unemployment spell before entry in the programme } \\
\hline Remaining UE benefits claim (in months)* & 2.24 & 2.08 & 2.25 & 2.34 & 2.08 & 3.42 \\
\hline No informatio & 56 & 59 & 55 & 53 & 56 & 36 \\
\hline$\leq 6$ months & 31 & 30 & 32 & 33 & 32 & 42 \\
\hline$\leq 1$ year & 43 & 40 & 44 & 47 & 43 & 63 \\
\hline$\leq 18$ & 44 & 41 & 45 & 47 & 43 & 64 \\
\hline$\leq 2$ years & 44 & 41 & 45 & 47 & 44 & 64 \\
\hline \multicolumn{7}{|c|}{ Legal UEE benefits claim at the beginning of the last unemployment spell before the programme } \\
\hline Legally claim* (months) & 5.73 & 5.15 & 5.78 & 5.52 & 5.52 & 6.27 \\
\hline No information & 25 & 27 & 21 & 22 & 20 & 16 \\
\hline No claim & 8 & 10 & 9 & 7 & 10 & 5 \\
\hline$\leq 6$ months & 15 & 16 & 19 & 20 & 22 & 23 \\
\hline$\leq 1$ year & 63 & 61 & 65 & 70 & 68 & 78 \\
\hline$\leq 18$ months & 66 & 62 & 69 & 70 & 69 & 79 \\
\hline Up to 2 years & 67 & 63 & 69 & 71 & 70 & 79 \\
\hline \multicolumn{7}{|c|}{ Unemployment benefits or assistance in the month before beginning of the programme } \\
\hline Unemployment benefits & 74 & 73 & 79 & 78 & 80 & 84 \\
\hline Unemployment assistance & 26 & 27 & 21 & 22 & 20 & 16 \\
\hline \multicolumn{7}{|c|}{ Various historical un/ out-of/employment information before the "first unemployment period" } \\
\hline last employment spell* & 15.74 & 14.96 & 16.58 & 16.35 & 15.15 & 17.16 \\
\hline Proportion of employment months (in \%)* & 63.38 & 72.13 & 77.10 & 77.54 & 75.01 & 79.29 \\
\hline Proportion of out-of-labou & 11.63 & 9.37 & 8.85 & & 9.60 & 5.77 \\
\hline UE month & 13.14 & 9.98 & 7.84 & 7.6 & 11.31 & 7.75 \\
\hline \# of programs up to 2 years before the UE period* & 0.18 & 0.17 & 0.11 & 0.11 & 0.11 & 0.14 \\
\hline \# of programs up to 5 years before the UE period* & 0.22 & 0.19 & 0.12 & 0.12 & 0.12 & 0.18 \\
\hline $\begin{array}{l}\text { \# of programs from entry in the data up to the UE } \\
\text { period (UEP)* }\end{array}$ & 0.23 & 0.19 & 0.12 & 0.12 & 0.14 & 0.18 \\
\hline Mean duration of UE spells up to 2 years before UEP* & 2.06 & 1.94 & 1.37 & 1.37 & 1.74 & 1.23 \\
\hline$\ldots$ of UE s & 3.08 & 2.24 & 1.7 & & 2.16 & 1.75 \\
\hline ... of UE spells from entry in data up to UEP* & 3.12 & 2.24 & 1.79 & 1.72 & 2.14 & 1.75 \\
\hline ... of employment spells up to 2 years before UEP* & 7.28 & 9.40 & 9.93 & 9.80 & 10.62 & 10.35 \\
\hline ... of employment spells up to 5 years before UEP* & 13.06 & 13.42 & 15.21 & 14.73 & 13.29 & 15.51 \\
\hline ... of employment spells from entry in data up to UEP* & 14.78 & 14.11 & 15.64 & 15.74 & 14.10 & 15.51 \\
\hline ... of out-of-labour spells up to 2 years before UEP* & 1.88 & 1.60 & 1.63 & 1.70 & 1.52 & 0.76 \\
\hline ... of out-of-labour spells up to 5 years before UEP* & 3.00 & 2.30 & 2.10 & 2.27 & 2.31 & 1.64 \\
\hline$\ldots$ of out-of-labour spells from entry in data up to UEP* & 3.34 & 2.33 & 2.26 & 2.32 & 2.31 & 1.64 \\
\hline
\end{tabular}

Table A.1 to be continued 


\begin{tabular}{|c|c|c|c|c|c|c|}
\hline & $\begin{array}{l}\text { Non- } \\
\text { partici- } \\
\text { pation }\end{array}$ & $\begin{array}{l}\text { Short } \\
\text { training }\end{array}$ & $\begin{array}{l}\text { Long } \\
\text { training }\end{array}$ & Retraining & $\begin{array}{c}\text { Practice } \\
\text { firm }\end{array}$ & Other \\
\hline $\begin{array}{l}\text { Total months in all prog. up to } 2 \text { years before the } \\
\text { UEP* }\end{array}$ & 2.10 & 1.46 & 0.89 & 0.71 & 0.69 & 1.19 \\
\hline $\begin{array}{l}\text { Total months in all prog. up to } 5 \text { years before the } \\
\text { UEP* }\end{array}$ & 2.42 & 1.66 & 0.95 & 0.77 & 0.75 & 1.51 \\
\hline Total months in all prog. before entry in sample ${ }^{*}$ & 2.47 & 1.66 & 0.95 & 0.77 & 0.85 & 1.51 \\
\hline \multicolumn{7}{|c|}{ Various un/employment information from the "first unemployment period" } \\
\hline Duration of the "first UE spell"* & 7.59 & 8.04 & 7.39 & 6.41 & 6.65 & 4.91 \\
\hline Duration of last UE spell before programme* & 6.66 & 6.44 & 6.23 & 5.12 & 5.72 & 3.98 \\
\hline $\begin{array}{l}\text { Time since beginning of last UE spell (before the } \\
\text { prog.) even if other state between UE and prog. }\end{array}$ & 6.68 & 8.17 & 7.46 & 6.58 & 6.56 & 4.89 \\
\hline Time between the prog. and last job* & 14.60 & 12.79 & 11.65 & 10.20 & 9.77 & 8.23 \\
\hline 3 months $\geq$ time between prog. and last job & 15 & 17 & 15 & 19 & 19 & 31 \\
\hline 6 months $\geq$ time between prog. and last job & 34 & 35 & 34 & 40 & 43 & 58 \\
\hline 12 months $\geq$ time between prog. and last job & 57 & 61 & 68 & 71 & 78 & 80 \\
\hline 24 months $\geq$ time between prog. and the job) & 78 & 86 & 87 & 93 & 94 & 92 \\
\hline \multicolumn{7}{|l|}{ Transition in 6 months before programme: } \\
\hline UE. $\rightarrow$ UE & 59 & 65 & 65 & 60 & 63 & 43 \\
\hline Empl. $\rightarrow$ UE & 26 & 28 & 29 & 31 & 31 & 49 \\
\hline Out $\rightarrow$ UE & 9 & 4 & 5 & 6 & 5 & 5 \\
\hline Prog. $\rightarrow$ UE & 5 & 3 & 1 & 3 & 1 & 3 \\
\hline \# of prog. in year before actual prog. ${ }^{*}$ & 0.11 & 0.05 & 0.02 & 0.05 & 0.02 & 0.08 \\
\hline \# of prog's in 6 months before actual prog. & 0.05 & 0.03 & 0.01 & 0.03 & 0.01 & 0.03 \\
\hline \multicolumn{7}{|c|}{ Regional Information (level of regional administrative unit: town, local district) } \\
\hline Big City & 17 & 17 & 14 & 13 & 10 & 3 \\
\hline Net migration per 1000 inhabitants & 14.16 & 13.41 & 9.75 & 9.84 & 6.38 & 3.76 \\
\hline Inhabitants below age 15 in $\%$ of the $15-65$ year olds & 19.42 & 20.19 & 21.00 & 21.48 & 21.40 & 23.39 \\
\hline Inhabitants above age 65 in \% of the $15-65$ year olds & 18.30 & 19.12 & 19.69 & 20.10 & 20.85 & 21.82 \\
\hline Inhabitants of age $15-65$ in $\%$ of all inhabitants & 59.19 & 61.63 & 63.23 & 63.60 & 63.63 & 67.98 \\
\hline Inhabitants above age 75 in $\%$ of all inhabitants & 4.23 & 4.68 & 4.94 & 5.07 & 5.23 & 5.82 \\
\hline Recipients of social assistance per 1000 inhabitants & 15.07 & 15.94 & 15.95 & 16.43 & 16.68 & 16.39 \\
\hline $\begin{array}{l}\text { Fraction of non-German nationals among recipients } \\
\text { of social assistancea }\end{array}$ & 10.51 & 8.10 & 9.71 & 9.98 & 14.75 & 11.51 \\
\hline Net migration per 1000 insured employees* & 77.25 & 66.92 & 37.52 & 0.48 & 5.36 & -83.82 \\
\hline Gross value added - fraction agriculture/forestry ${ }^{*}$ & 0.65 & 0.78 & 1.14 & 1.36 & 1.54 & 2.22 \\
\hline Gross value added - fraction other services* ${ }^{*}$ & 42.08 & 44.10 & 45.44 & 44.90 & 45.91 & 47.07 \\
\hline Gross value added - fraction manufacturing ${ }^{*}$ & 30.55 & 31.63 & 32.41 & 33.39 & 32.32 & 37.65 \\
\hline Gross value added - fraction commerce / transport ${ }^{*}$ & 10.00 & 10.78 & 11.16 & 11.49 & 11.83 & 11.90 \\
\hline Gross value added in DM per inhabitant* ${ }^{\star}$ & 21290 & 22407 & 22540 & 22184 & 22067 & 21844 \\
\hline Tax revenue in DM per inhabitant & 159 & 164 & 161 & 174 & 164 & 160 \\
\hline Rural areas & 20 & 15 & 22 & 24 & 28 & 30 \\
\hline $\begin{array}{l}\text { Core cities and highly concentrated districts in } \\
\text { agglomerations }\end{array}$ & 13 & 14 & 14 & 12 & 9 & 5 \\
\hline Concentrated and rural districts in agglomerations & 19 & 21 & 20 & 21 & 14 & 23 \\
\hline Urbanised areas & 36 & 40 & 37 & 36 & 42 & 42 \\
\hline Berlin, Postdam & 11 & 7 & 7 & 9 & 4 & 1 \\
\hline Saxony, Thuringia & 40 & 46 & 47 & 41 & 46 & 56 \\
\hline Mecklenburg-Western-Pomerania, Brandenburg & 10 & 14 & 15 & 18 & 12 & 10 \\
\hline Saxony-Anhalt & 17 & 10 & 14 & 13 & 27 & 19 \\
\hline
\end{tabular}

Table A.1 to be continued 
Table: A.1: Descriptive statistics (continued-3)

\begin{tabular}{|c|c|c|c|c|c|c|c|}
\hline & & $\begin{array}{l}\text { Nonpartici- } \\
\text { pation }\end{array}$ & $\begin{array}{c}\text { Short } \\
\text { training }\end{array}$ & $\begin{array}{l}\text { Long } \\
\text { training }\end{array}$ & Retraining & $\begin{array}{c}\text { Practice } \\
\text { firm }\end{array}$ & Other \\
\hline \multicolumn{2}{|l|}{ UE rate $\leq 15 \%$} & 35 & 33 & 37 & 34 & 27 & 29 \\
\hline \multicolumn{2}{|l|}{$15 \%<$ UE rate $\leq 20 \%$} & 58 & 58 & 56 & 56 & 58 & 57 \\
\hline \multicolumn{2}{|l|}{ UE rate $>20 \%$} & 7 & 9 & 7 & 10 & 15 & 14 \\
\hline \multicolumn{8}{|c|}{ Firms size of the last employer } \\
\hline \multicolumn{2}{|l|}{ No information } & 19 & 14 & 14 & 7 & 9 & 12 \\
\hline \multicolumn{2}{|l|}{1 to 9 employees } & 15 & 12 & 14 & 14 & 10 & 26 \\
\hline \multicolumn{2}{|l|}{10 to 99 employees } & 29 & 28 & 28 & 34 & 37 & 30 \\
\hline \multicolumn{2}{|l|}{100 to 499 employees } & 21 & 25 & 23 & 24 & 20 & 18 \\
\hline \multicolumn{2}{|l|}{500 employees or more } & 16 & 21 & 21 & 20 & 24 & 14 \\
\hline \multicolumn{8}{|c|}{ Date of entry and exit from the sample } \\
\hline \multicolumn{2}{|l|}{ Date of entry in the data* } & Dec. 90 & Jun. 91 & Jun. 91 & Apr. 91 & Apr. 91 & Jun. 91 \\
\hline \multicolumn{2}{|l|}{ Date of entry in the sample* } & Nov. 93 & Aug. 93 & Sep. 93 & Aug. 93 & Jul. 93 & Aug. 93 \\
\hline Date of beginning of prog. * & & Jul. 94 & Jun. 94 & Mai 94 & Apr. 94 & Fev. 94 & Fev. 94 \\
\hline \multirow{2}{*}{\multicolumn{2}{|c|}{ I nomploymont in lon 1001}} & Outcome+ & & & & & \\
\hline & 3326 & 6.1 & 2.7 & 1.6 & 3.5 & 6.6 & 3.3 \\
\hline 1992 & 5911 & 31.2 & 23.9 & 20.1 & 16.8 & 19.4 & 25.9 \\
\hline 1993 & 6150 & 40.0 & 38.8 & 30.6 & 32.2 & 26.5 & 32.5 \\
\hline 1994 & 6194 & 71.2 & 76.6 & 80.7 & 80.7 & 86.4 & 51.7 \\
\hline 1995 & 6196 & 62.9 & 68.9 & 83.6 & 93.3 & 63.6 & 12.7 \\
\hline 1997 & 6196 & 46.2 & 43.0 & 37.9 & 51.2 & 44.4 & 21.2 \\
\hline 1999 & 6196 & 39.3 & 34.0 & 33.6 & 34.8 & 40.1 & 17.8 \\
\hline 2001 & 6196 & 33.7 & 33.0 & 30.0 & 30.3 & 35.2 & 15.3 \\
\hline 2002 & 6148 & 32.2 & 31.2 & 31.7 & 30.0 & 36.9 & 19.8 \\
\hline \multirow[t]{9}{*}{ Employment in } & 3326 & 90.8 & 94.5 & 97.6 & 92.9 & 93.4 & 95.0 \\
\hline & 5911 & 60.0 & 69.2 & 73.7 & 75.2 & 70.3 & 71.6 \\
\hline & 6150 & 50.2 & 53.9 & 61.9 & 59.0 & 63.0 & 62.4 \\
\hline & 6194 & 21.9 & 20.9 & 16.0 & 16.0 & 12.4 & 47.5 \\
\hline & 6196 & 26.2 & 28.4 & 14.1 & 4.3 & 33.3 & 85.6 \\
\hline & 6196 & 34.4 & 48.6 & 51.5 & 40.2 & 46.3 & 72.0 \\
\hline & 6196 & 39.1 & 52.3 & 51.7 & 54.6 & 49.4 & 72.9 \\
\hline & 6196 & 37.3 & 49.5 & 49.3 & 52.6 & 47.5 & 71.2 \\
\hline & 6148 & 36.4 & 51.4 & 46.3 & 51.4 & 43.3 & 65.3 \\
\hline \multirow[t]{10}{*}{ Out-of-Labour in Jar } & 3326 & 3.3 & 2.7 & 0.8 & 3.5 & 0.0 & 1.7 \\
\hline & 5911 & 8.8 & 6.9 & 6.2 & 7.8 & 10.3 & 2.6 \\
\hline & 6150 & 9.8 & 7.3 & 7.5 & 8.6 & 10.5 & 5.1 \\
\hline & 6194 & 7.1 & 2.5 & 3.4 & 3.4 & 1.2 & 1.0 \\
\hline & 6196 & 10.8 & 2.8 & 2.2 & 2.5 & 3.1 & 1.7 \\
\hline & 6196 & 19.3 & 8.4 & 10.6 & 8.5 & 9.3 & 6.8 \\
\hline & 6196 & 21.7 & 13.7 & 14.5 & 10.6 & 10.5 & 9.3 \\
\hline & 6196 & 29.0 & 17.5 & 20.8 & 17.1 & 17.3 & 13.6 \\
\hline & 6148 & 31.4 & 17.4 & 22.1 & 18.6 & 19.7 & 14.9 \\
\hline & 6148 & 5.8 & 7.3 & 6.5 & 4.2 & 7.6 & 4.1 \\
\hline
\end{tabular}

Note: $\quad$ The sample used for the table is the one after all selection steps described in Section 3, but before imposing the common support requirement. Entries that do not add up to $100 \%$ within a group of dummy variables are due to observations with missing information, and rounding. *The results for variables marked with an asterisk are means rather than proportions. ${ }^{* *}$ Local unemployment rates for each of the 141 local labour office districts. + The different outcomes do not add up to $100 \%$ because of some missing values. ++ The category 'No information' includes both cases with missing earnings information and with the entry ' 0 '. Zero entries are made for so-called inactive employment which includes women on maternity leave, men in the military or civil service, as well as employees having been ill for more than six weeks. The first column gives the number of observations used to compute the proportions. The sample size decreases due to different entry dates into the sample (first UE spell in 93/94) and exit dates from the sample. Career improvement is omitted because it contains only 8 individuals. 


\title{
Appendix B: Technical details of the matching estimator used
}

\author{
Table B.1: A matching protocol for the estimation of $\theta_{0}^{m, l}$
}

\begin{tabular}{|c|c|}
\hline Step 1 & $\begin{array}{l}\text { Specify and estimate a multinomial probit model to obtain the marginal choice probabilities (see Appendix B): } \\
{\left[\hat{P}_{N}^{0}(x), \hat{P}_{N}^{1}(x), \hat{P}_{N}^{2}(x), \hat{P}_{N}^{3}(x)\right] ; \hat{P}_{N}^{l}(x):=\hat{P}_{N}(S=l \mid X=x)}\end{array}$ \\
\hline Step 2 & $\begin{array}{l}\text { Restrict sample to common support: Delete all observations with probabilities larger than the smallest maximum } \\
\text { and smaller than the largest minimum of all subsamples defined by S. }\end{array}$ \\
\hline Step 3 & 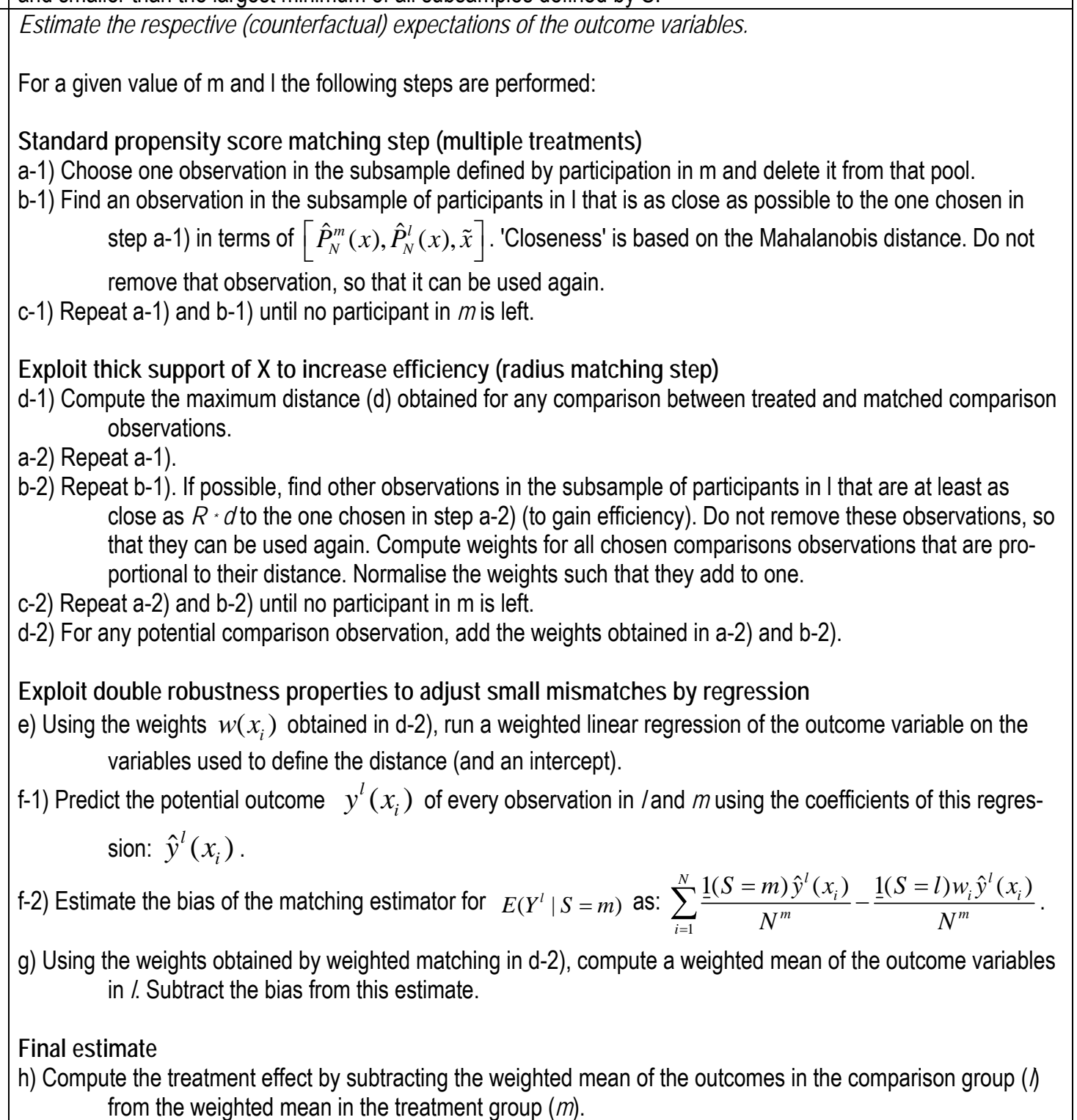 \\
\hline Step 4 & Repeat Step 3 for all combinations of $m$ and $l$. \\
\hline Note: & $\begin{array}{l}\text { Lechner (2001) suggests an estimator of the asymptotic standard errors for } \hat{\theta}_{N}^{m, l} \text { conditional on the weights that } \\
\text { we use here. } \tilde{X} \text { includes the date of the beginning of the programme, sex, three dummies indicating if the individ- } \\
\text { ual is employed (and observed) } 12,24 \text { and } 36 \text { months before the programme. } \tilde{X} \text { is included to ensure a high } \\
\text { match quality with respect to these critical variables. } R \text { is fixed to } 90 \% \text { in this application (different values are } \\
\text { checked in the sensitivity analysis). Note that once we estimate all } E\left(Y^{l} \mid S=m \text { ) for all m, they can be directly }\right. \\
\text { used to obtain } E\left(Y^{l}\right) \text {. }\end{array}$ \\
\hline
\end{tabular}




\section{Tables and Figures}

\section{Tables}

Table 1: Expenditure on active and passive labour market policies 1991-2003

\begin{tabular}{cccccccc}
\hline \hline & 1991 & 1993 & 1995 & 1997 & 1999 & 2001 & 2003 \\
\hline Total expenditure in million EUR & 25,008 & 35,425 & 39,275 & 42,781 & 41,858 & 40,745 & 47,613 \\
\hline & \multicolumn{2}{c}{ Shares of total expenditure for active and passive labour market policy in } \\
Training & 13 & 10 & 10 & 8 & 10 & 11 & 7 \\
Temporary wage subsidy & 1 & $<1$ & $<1$ & $<1$ & 2 & 2 & 1 \\
Short-time work & 1 & 5 & 1 & 1 & 1 & 1 & 1 \\
Job creation schemes & 6 & 4 & 4 & 3 & 3 & 2 & 1 \\
Early retirement & 1 & $<1$ & $<1$ & $<1$ & $<1$ & 1 & 2 \\
Rehabilitation programmes & 7 & 6 & 4 & 4 & 4 & 5 & 5 \\
\hline Unemployment benefits & 33 & 43 & 46 & 47 & 39 & 40 & 44 \\
Unemployment assistance & 14 & 15 & 19 & 23 & 24 & 18 & 19 \\
Other expenditure & 25 & 18 & 15 & 13 & 17 & 19 & 19 \\
\hline Unemployment rate in \% & 6.2 & 8.0 & 9.1 & 10.8 & 9.6 & 8.0 & 9.3 \\
\hline
\end{tabular}

Sources: BA (1992-2004).

Notes: Training: further training, retraining, short training according to §41a EPA (abolished at the end of 1992). Temporary wage subsidies are subsidies during the phase of initial skill adaptation in a new job (Einarbeitungs-zuschüsse). 'Other expenditure' mainly includes counselling and job placement services as well as administrative costs of the public employment service (PES). 
Table 2: Definition of programmes

\begin{tabular}{|c|c|}
\hline Programme & Description \\
\hline Short training & Further training in the profession held with planned duration $\leq 6$ months. \\
\hline Long training & Further training in the profession held with planned duration $>6$ months. \\
\hline Retraining & $\begin{array}{l}\text { Training to obtain a new professional degree in a field other than the profession } \\
\text { currently held. }\end{array}$ \\
\hline Practice firm & Further training that simulates a job in a specific field of profession \\
\hline Other programmes & $\begin{array}{l}\text { Career improvement: Further training to obtain a higher professional degree, e.g. } \\
\text { master craftsman, technician, or a (below university) degree in business administration. } \\
\text { Residual cateoorv: Various verv small and heterogeneous nrogrammes }\end{array}$ \\
\hline
\end{tabular}

Note: Due to insufficient sample size the category other programmes is not evaluated in this study. 
Table 3: Combined data sources used

\begin{tabular}{|c|c|c|c|}
\hline & ES & BPR & TPD \\
\hline Source & $\begin{array}{l}\text { Employer supplied mandatory } \\
\text { social insurance entries. }\end{array}$ & $\begin{array}{l}\text { Benefit payment register of } \\
\text { the PES } 1975-1997 .\end{array}$ & $\begin{array}{l}\text { Questionnaires filled in by the } \\
\text { labour officer for statistical } \\
\text { purposes (ST35). }\end{array}$ \\
\hline Population & $\begin{array}{l}1 \% \text { random sample of persons } \\
\text { covered by social insurance for } \\
\text { at least one day } 1975-1997 \text {. } \\
\text { Self-employed, civil servants, } \\
\text { university students are not } \\
\text { included. Data until } 2002 \text {. }\end{array}$ & $\begin{array}{l}\text { Recipients of benefit pay- } \\
\text { ments from the PES 1975- } \\
2002 \text {. }\end{array}$ & $\begin{array}{l}\text { Participants in further } \\
\text { training, retraining, short } \\
\text { training, German language } \\
\text { courses and temporary wage } \\
\text { subsidies } 1975-1997 \text {. }\end{array}$ \\
\hline $\begin{array}{l}\text { Available } \\
\text { information }\end{array}$ & $\begin{array}{l}\text { Personal characteristics and } \\
\text { history of employment. }\end{array}$ & $\begin{array}{l}\text { Information about the } \\
\text { receipt of benefit payments } \\
\text { from the public } \\
\text { employment service. }\end{array}$ & $\begin{array}{l}\text { Personal characteristics of } \\
\text { participants and information } \\
\text { about training programmes. }\end{array}$ \\
\hline $\begin{array}{l}\text { Important } \\
\text { variables }\end{array}$ & $\begin{array}{l}\text { Gender, age, nationality, educa- } \\
\text { tion, profession, occupational } \\
\text { status, industry, firm size, } \\
\text { earnings, regional information. }\end{array}$ & $\begin{array}{l}\text { Type and amount of } \\
\text { benefits received. }\end{array}$ & $\begin{array}{l}\text { Type, duration and result of } \\
\text { the programme, type of } \\
\text { income support paid during } \\
\text { participation. }\end{array}$ \\
\hline Structure & $\begin{array}{l}\text { Spells based on daily informa- } \\
\text { tion. }\end{array}$ & $\begin{array}{l}\text { Spells based on daily } \\
\text { information. }\end{array}$ & $\begin{array}{l}\text { Spells based on monthly } \\
\text { information. }\end{array}$ \\
\hline
\end{tabular}

Note: The merged data is based on monthly information. For detailed information on the merging and recoding procedures see Bender et al. (2005). The creation of this data base is a result of a three year joint project of research groups at the Universities of Mannheim (Bergemann, Fitzenberger, Speckesser) and St. Gallen (Lechner, Miquel, Wunsch) as well as the Institute for Employment Research of the FEA (Bender). 
Table 4: Future programme participation until 1997 by treatment status

\begin{tabular}{lccccc}
\hline \hline & \multicolumn{5}{c}{ Treatment status in study (first treatment) } \\
\hline Future programme participation until & $\begin{array}{c}\text { Nonparticipatio } \\
1997\end{array}$ & $\begin{array}{c}\text { Practice } \\
\text { firm }\end{array}$ & $\begin{array}{c}\text { Short train- } \\
\text { ing }\end{array}$ & $\begin{array}{c}\text { Long } \\
\text { training }\end{array}$ & Retraining \\
\hline No future programme & 89.1 & 81.5 & 76.3 & 86.0 & 90.7 \\
Practice firm & 1.7 & 8.5 & 1.5 & 0.8 & 0.8 \\
Short training & - & - & 1.5 & - & 0.3 \\
Long training & 7.6 & 8.1 & 13.5 & 10.6 & 4.4 \\
Retraining & 1.7 & 2.7 & 8.3 & 2.9 & 4.1 \\
Other & 0.3 & 0.4 & 0.6 & 0.3 & 0.3 \\
Total other treatments than first & 10.9 & 18.5 & 23.7 & 14.0 & 9.3 \\
treatment & & & &
\end{tabular}

Note: Entries show the fraction (\%) of members of the subsamples stated in the columns who participated at least once in the treatments stated in rows after their first treatment (programme participants) or after 12 months after entering unemployment (nonparticipants). Due to data limitations only training spells completed by the end of 1997 are observable. *Other includes all training programmes we observe in the data but which we do not evaluate due to insufficient sample sizes (see Table 2). 
Table 5: Means of selected variables by treatment status

\begin{tabular}{|c|c|c|c|c|c|}
\hline & $\begin{array}{c}\text { Non- } \\
\text { participation }\end{array}$ & $\begin{array}{l}\text { Practice } \\
\text { firm }\end{array}$ & $\begin{array}{c}\text { Short } \\
\text { training }\end{array}$ & $\begin{array}{c}\text { Long } \\
\text { training }\end{array}$ & $\begin{array}{c}\text { Re- } \\
\text { training }\end{array}$ \\
\hline Observations & 15,687 & 259 & 482 & 385 & 387 \\
\hline Woman & 46 & 37 & 43 & 45 & 38 \\
\hline Age in months ${ }^{+}$ & 36 & 36 & 35 & 35 & 31 \\
\hline Age below 26 years & 17 & 14 & 16 & 14 & 21 \\
\hline Age above 50 years & 13 & 6 & 6 & 6 & 1 \\
\hline Married $^{+}$ & 53 & 44 & 47 & 42 & 43 \\
\hline No children $^{+}$ & 62 & 67 & 62 & 64 & 62 \\
\hline German citizenship $^{+}$ & 82 & 83 & 90 & 91 & 87 \\
\hline University entrance school degree $^{+}$ & 3 & 3 & 4 & 7 & 5 \\
\hline No vocational degree $^{+}$ & 25 & 20 & 16 & 13 & 28 \\
\hline Vocational degree $^{+}$ & 69 & 79 & 78 & 74 & 67 \\
\hline University or college degree $^{+}$ & 5 & 0 & 5 & 13 & 4 \\
\hline Unskilled worker* & 37 & 38 & 29 & 22 & 48 \\
\hline Skilled worker* & 22 & 21 & 21 & 14 & 18 \\
\hline White-collar worker* & 29 & 32 & 37 & 52 & 25 \\
\hline Part-time worker* & 11 & 6 & 8 & 10 & 7 \\
\hline Last monthly earnings from employment in EUR* & 1,396 & 1,434 & 1,570 & 1,672 & 1,558 \\
\hline Federal state: Schleswig-Holstein, Hamburg, Bremen & 22 & 31 & 22 & 22 & 23 \\
\hline Federal state: Northrhine-Westphalia & 30 & 20 & 28 & 34 & 33 \\
\hline Federal state: Rhineland-Palatinate, Hesse, Saarland & 17 & 20 & 16 & 18 & 17 \\
\hline Federal state: Baden-Württemberg, Bavaria & 31 & 29 & 35 & 25 & 27 \\
\hline Legal unemployment benefit claim in months ${ }^{+}$ & 10 & 9 & 10 & 9 & 8 \\
\hline $\begin{array}{l}\text { Time to participation in months within relevant UE } \\
\text { spell }\end{array}$ & 4 & 6 & 5 & 6 & 5 \\
\hline $\begin{array}{l}\text { Fraction of months unemployed since begin of first } \\
\text { employment in life that was subject to social security } \\
\text { contributions }\end{array}$ & 8 & 10 & 9 & 7 & 7 \\
\hline Fraction of months employed since ... ${ }^{+}$ & 71 & 67 & 69 & 68 & 67 \\
\hline Planned programme duration in months & - & 7 & 4 & 10 & 21 \\
\hline
\end{tabular}

Note: If not stated otherwise, entries are in per cent and measured at (simulated) programme start. *Refers to the last employment before relevant unemployment spell. ${ }^{+}$Measured at entry into unemployment. 
Table 6: Estimated employment effects eight years after programme start

\begin{tabular}{lccccc}
\hline \hline & $\begin{array}{c}\text { Nonparticipatio } \\
\text { n }\end{array}$ & Practice firm & Short training & Long training & Retraining \\
\hline$m$ & & \multicolumn{2}{c}{ (a) Estimate of $E\left(Y^{l} \mid S=m\right)$} \\
\hline Nonparticipation & 49.4 & 58.4 & 64.5 & 58.5 & 68.1 \\
Practice firm & 46.4 & 55.1 & 62.1 & 61.8 & 66.1 \\
Short training & 48.7 & 59.1 & 62.4 & 60.9 & 75.6 \\
Long training & 52 & 61.3 & 59.8 & 61.1 & 75.3 \\
Retraining & 51.3 & 65.3 & 66 & 62.7 & 69.6 \\
\hline
\end{tabular}

$m$

Nonparticipation

Practice firm

Short training

Long training

Retraining

(b) Estimate of $\theta_{0}^{m, l}=E\left(Y^{m}-Y^{l} \mid S=m\right)$

\begin{tabular}{ccccc}
0 & $\mathbf{- 9 . 0}$ & $\mathbf{- 1 5 . 1 *}$ & $\mathbf{- 9 . 1}$ & $\mathbf{- 1 8 . 7 *}$ \\
$\mathbf{8 . 7}$ & 0 & -7.0 & -6.7 & $\mathbf{- 1 1 . 0}$ \\
$\mathbf{1 3 . 7}^{*}$ & 3.3 & 0 & 1.5 & $\mathbf{- 1 3 . 2 *}$ \\
$\mathbf{9 . 1}^{*}$ & -0.2 & 1.3 & 0 & $\mathbf{- 1 4 . 2 *}$ \\
$\mathbf{1 8 . 3}^{*}$ & 4.3 & 3.6 & 6.9 & 0 \\
\hline
\end{tabular}

(c) Sample size after imposing common support

$\begin{array}{lllll}12,681 & 243 & 431 & 303 & 352\end{array}$

(d) Approximate average programme cost per participant in $\mathrm{EUR}^{+}$

$\begin{array}{llll}6,565 & 4,439 & 9,930 & 20,983\end{array}$

Note: Bold numbers indicate significance at the 5\% level, numbers in italics relate to the $10 \%$ level and $*$ to the $1 \%$ level. ${ }^{+}$The approximate cost of one month spent in a programme is 1,200 EUR (incl. income support and direct programme cost). This number is multiplied by the mean programme duration in each group. 
Table 7: Effect heterogeneity (employment) eight years after programme start (difference in \%-points) $\left(\hat{\theta}_{96}^{m l}\right)$

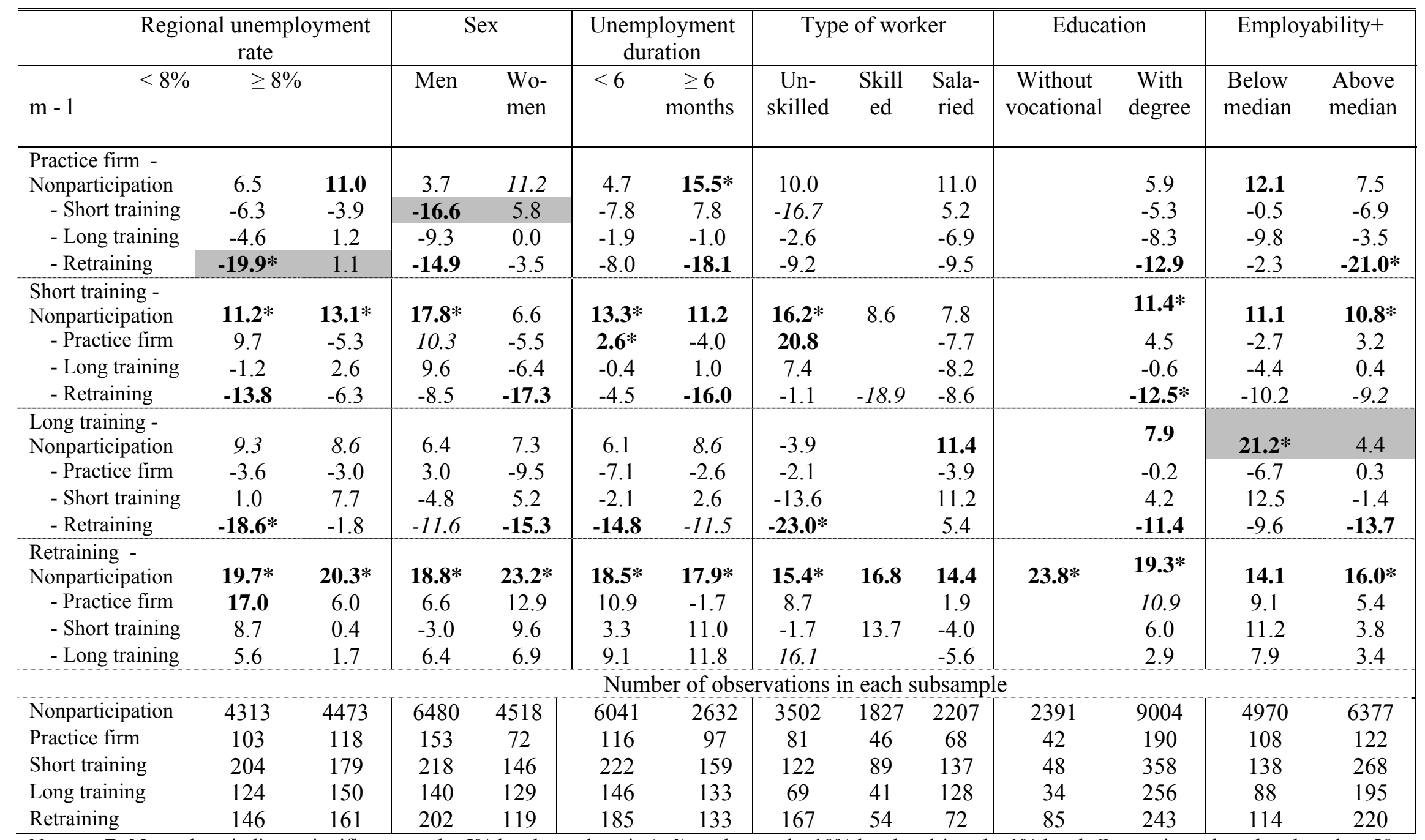

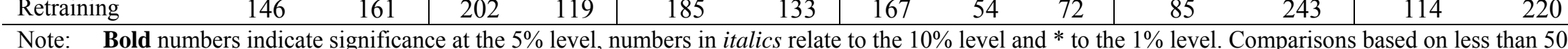
observations are not reported in the table. Cells shaded in grey indicate that the difference of the two estimated effects is significant at the $5 \%$ level. +

Predicted probability to be employed 4 years after programme start where the underlying coefficients are estimated by a probit model using nonparticipants only. To split the sample the median of the distribution among nonparticipants is used (0.448). 
Table 8: Long-run outcomes of alternative assignment rules

\begin{tabular}{|c|c|c|c|}
\hline No. & Assignment rule & $\begin{array}{l}\text { Mean employ- } \\
\text { ment rate in \% }\end{array}$ & $\begin{array}{l}\text { Approximate } \\
\text { programme cost } \\
\text { in million EUR }\end{array}$ \\
\hline 1 & Actual allocation & 50.7 & 13.0 \\
\hline 2 & Everyone assigned to nonparticipation & 49.4 & - \\
\hline 3 & Everyone assigned to practice firm & 58.6 & 82.7 \\
\hline 4 & Everyone assigned to short training & 64.3 & 55.9 \\
\hline 5 & Everyone assigned to long training & 58.8 & 125.0 \\
\hline 6 & Everyone assigned to retraining & 68.5 & 264.2 \\
\hline 7 & $\begin{array}{l}\text { Participants in practice firm assigned to short training, participants } \\
\text { in long training assigned to retraining }\end{array}$ & 51.2 & 15.9 \\
\hline 8 & $\begin{array}{l}\text { Same as } 7 \text { but } 50 \% \text { of nonparticipants assigned to short training } \\
\text { and } 50 \% \text { of nonparticipants assigned to retraining }\end{array}$ & 66.4 & 160.0 \\
\hline 9 & $\begin{array}{l}\text { Participants in practice firm assigned to long training, } \\
\text { corresponding number of participants in long training assigned to } \\
\text { practice firm such that the overall fractions of participants in each } \\
\text { programme remain unchanged }\end{array}$ & 50.8 & 13.0 \\
\hline Note: & $\begin{array}{l}\text { Mean employment rates are calculated from Table } 6 \text { panel (a) and } \\
\text { imposing common support. The approximate cost of one month }\end{array}$ & $\begin{array}{l}\text { fraction of } \mathrm{p} \\
\text { in a program }\end{array}$ & $\begin{array}{l}\text { in each stat } \\
\text { s } 1,200 \text { EUR }\end{array}$ \\
\hline
\end{tabular}


Table A.1: Sample selection rules and remaining numbers of observations

\begin{tabular}{lcccccc}
\hline \hline & $\begin{array}{c}\text { Nonpar- } \\
\text { ticipation }\end{array}$ & $\begin{array}{c}\text { Practice } \\
\text { firm }\end{array}$ & $\begin{array}{c}\text { Short } \\
\text { training }\end{array}$ & $\begin{array}{c}\text { Long } \\
\text { training }\end{array}$ & Retraining & Other \\
\hline $\begin{array}{c}\text { Persons entering unemployment } \\
\text { between Jan. 1992 and Jun. 1994 }\end{array}$ & 37,440 & 289 & 520 & 429 & 452 & 317 \\
\hline
\end{tabular}

Eligibility: Only individuals receiving UB or UA in the month before (simulated) programme start

Remaining observations

24,354

279

505

412

412

288

Simulated programme start of nonparticipants within 12 months after entering unemployment and receipt of UB or UA in this month

$\begin{array}{lllllll}\text { Remaining observations } & 21,379 & 279 & 505 & 412 & 412 & 288\end{array}$

Personal characteristics : a) $20 \leq$ age $\leq 55$; b) no trainees or apprentices; c) at least one observation of employment;

d) no home workers; e) no part-time worker below half of full-time equivalent

Final sample

15,687

259

482

385

387

263

Note: All variables are measured in the period before programme start. 


\begin{tabular}{|c|c|c|c|c|c|}
\hline & $\begin{array}{l}\text { Nonpar- } \\
\text { ticipation }\end{array}$ & $\begin{array}{l}\text { Practice } \\
\text { firm }\end{array}$ & $\begin{array}{l}\text { Short } \\
\text { training }\end{array}$ & $\begin{array}{l}\text { Long } \\
\text { training }\end{array}$ & Retraining \\
\hline \multirow[t]{2}{*}{ Observations } & 15,687 & 259 & 482 & 385 & 387 \\
\hline & \multicolumn{5}{|c|}{ Personal characteristics } \\
\hline Woman & 45.7 & 37.1 & 42.9 & 45.2 & 38.2 \\
\hline Age in years & 36.0 & 36.0 & 34.8 & 35.2 & 31.0 \\
\hline Below age 25 & 17.0 & 14.3 & 16.2 & 13.8 & 20.7 \\
\hline Above age 50 & 12.9 & 6.2 & 6.0 & 6.0 & 0.8 \\
\hline Not married & 46.8 & 55.6 & 52.7 & 57.9 & 57.1 \\
\hline Married & 53.2 & 44.4 & 47.3 & 42.1 & 42.9 \\
\hline No child & 62.1 & 66.8 & 62.0 & 63.6 & 62.3 \\
\hline At least one child & 37.9 & 33.2 & 38.0 & 36.4 & 37.7 \\
\hline German nationality & 82.0 & 82.6 & 89.6 & 90.9 & 86.6 \\
\hline Western European nationality & 11.1 & 7.7 & 6.2 & 3.4 & 8.0 \\
\hline Eastern European nationality & 3.7 & 5.8 & 1.2 & 2.6 & 2.3 \\
\hline Other nationality & 3.2 & 3.9 & 2.9 & 3.1 & 3.1 \\
\hline $\begin{array}{l}\text { No university entrance school degree, no vocational } \\
\text { degree }\end{array}$ & 23.9 & 19.7 & 15.4 & 11.9 & 26.1 \\
\hline No university entrance school degree, vocational degree & 66.4 & 76.8 & 74.3 & 68.1 & 63.8 \\
\hline University entrance school degree, no vocational degree & 0.8 & 0.8 & 0.6 & 1.0 & 2.3 \\
\hline University entrance school degree, vocational degree & 2.6 & 2.3 & 3.7 & 5.7 & 2.8 \\
\hline College degree & 1.7 & 0.4 & 3.1 & 5.2 & 1.6 \\
\hline \multirow[t]{2}{*}{ University degree. } & 3.2 & 0.0 & 2.3 & 7.5 & 2.8 \\
\hline & \multicolumn{5}{|c|}{ Regional information } \\
\hline Schleswig-Holstein, Hamburg, Bremen & 21.8 & 31.3 & 21.8 & 22.1 & 22.7 \\
\hline Northrhine-Westphalia & 29.6 & 20.5 & 27.6 & 33.5 & 33.1 \\
\hline Rhineland-Palatinate, Hesse, Saarland & 17.5 & 19.7 & 15.8 & 18.2 & 16.5 \\
\hline Baden-Württemberg, Bavaria & 30.8 & 28.6 & 34.9 & 25.2 & 27.1 \\
\hline Local unemployment rate & 8.3 & 8.3 & 8.1 & 8.4 & 8.4 \\
\hline
\end{tabular}




\begin{tabular}{|c|c|c|c|c|c|}
\hline & $\begin{array}{l}\text { Nonpar- } \\
\text { ticipation }\end{array}$ & $\begin{array}{l}\text { Practice } \\
\text { firm }\end{array}$ & $\begin{array}{l}\text { Short } \\
\text { training }\end{array}$ & $\begin{array}{l}\text { Long } \\
\text { training }\end{array}$ & Retraining \\
\hline $\begin{array}{l}\text { City with more than } 100,000 \text { inhabitants } \\
\text {. }\end{array}$ & 30.8 & 24.7 & 18.3 & 20.0 & 24.3 \\
\hline \multirow[t]{2}{*}{ City with more than 300,000 inhabitants } & 16.1 & 8.5 & 5.0 & 4.2 & 8.5 \\
\hline & \multicolumn{5}{|c|}{ Timing variables } \\
\hline Beginning of unemployment spell & Mar 93 & Feb 93 & Feb 93 & Apr 96 & Apr 93 \\
\hline Programme start date & Aug 93 & Sep 93 & Jul 93 & Oct 93 & Oct 93 \\
\hline \multirow[t]{2}{*}{ Time to treatment in months } & 4.3 & 5.7 & 5.2 & 5.6 & 5.0 \\
\hline & \multicolumn{5}{|c|}{ Benefit claim } \\
\hline Receipt of unemployment benefits (UB) & 90.0 & 86.5 & 91.7 & 89.1 & 86.8 \\
\hline Receipt of unemployment assistance & 10.0 & 13.5 & 8.3 & 10.9 & 13.2 \\
\hline UB claim at beginning of unemployment in months ${ }^{+}$ & 10.5 & 9.3 & 9.6 & 9.4 & 8.1 \\
\hline \multirow[t]{2}{*}{ UB claim at programme start in months } & 7.3 & 5.3 & 5.6 & 5.2 & 4.4 \\
\hline & \multicolumn{5}{|c|}{ Characteristics of last employment* } \\
\hline Unskilled worker & 36.9 & 38.2 & 29.0 & 21.6 & 48.3 \\
\hline Skilled worker & 20.8 & 20.8 & 21.4 & 14.3 & 17.8 \\
\hline Master craftsman & 0.9 & 0.8 & 0.4 & 0.5 & 0.5 \\
\hline White-collar worker & 28.6 & 32.0 & 36.9 & 51.7 & 24.5 \\
\hline Part-time worker & 10.6 & 5.8 & 8.1 & 9.9 & 6.7 \\
\hline Last monthly earnings in EUR & 1396 & 1434 & 1570 & 1672 & 1558 \\
\hline Firm size 1-9 employees & 20.6 & 18.1 & 20.7 & 20.0 & 21.2 \\
\hline Firm size 10-99 employees & 36.0 & 39.4 & 35.7 & 36.1 & 35.1 \\
\hline Firm size 100-499 employees & 20.2 & 22.0 & 18.7 & 20.3 & 21.2 \\
\hline Firm size 500 or more employees & 17.5 & 15.1 & 15.6 & 17.7 & 18.6 \\
\hline Technical profession & 16.9 & 17 & 17 & 12.1 & 20.7 \\
\hline Construction worker & 9.1 & 9.7 & 6.4 & 4.9 & 7.2 \\
\hline Office worker & 13.9 & 24.7 & 22.4 & 25.5 & 12.7 \\
\hline Service provider & 15.7 & 11.6 & 10.7 & 9.9 & 19.9 \\
\hline Production worker & 12 & 10.1 & 9.4 & 9.1 & 11.4 \\
\hline Other occupation & 32.4 & 26.9 & 34.1 & 38.5 & 28.1 \\
\hline Agriculture, forestry, fishing, mining, electricity supply & 1.6 & 4.2 & 0.8 & 0.3 & 1.8 \\
\hline Manufacturing & 37.8 & 39.8 & 36.7 & 37.9 & 37.7 \\
\hline Construction & 7.7 & 6.6 & 6.2 & 4.7 & 5.4 \\
\hline Commerce & 15.3 & 13.5 & 18.5 & 16.9 & 10.9 \\
\hline Logistics & 4.4 & 2.7 & 6.0 & 6.2 & 7.8 \\
\hline \multirow[t]{2}{*}{ Services } & 30.7 & 30.5 & 27.7 & 31.5 & 34.5 \\
\hline & \multicolumn{5}{|c|}{ Employment history } \\
\hline Number of programmes in last 2 years & 0.0 & 0.1 & 0.1 & 0.1 & 0.0 \\
\hline Number of programmes in last 5 years & 0.1 & 0.2 & 0.2 & 0.2 & 0.1 \\
\hline Number of programmes in the past & 0.2 & 0.3 & 0.2 & 0.3 & 0.2 \\
\hline Months in programmes in last 2 years & 0.2 & 0.4 & 0.5 & 0.5 & 0.1 \\
\hline Months in programmes in last 5 years & 0.7 & 1.5 & 1.3 & 1.4 & 0.6 \\
\hline Months in programmes in the past & 1.1 & 2.0 & 1.7 & 1.9 & 1.1 \\
\hline Number of employments in last 2 years & 1.2 & 1.2 & 1.2 & 1.2 & 1.2 \\
\hline Number of employments in last 5 years & 1.7 & 1.9 & 1.7 & 1.7 & 1.8 \\
\hline Number of employments in the past & 2.8 & 3.2 & 2.9 & 2.6 & 3.0 \\
\hline Months in employment in last 2 years & 18.2 & 18.1 & 18.3 & 18.6 & 18.5 \\
\hline Months in employment in last 5 years & 40.8 & 38.9 & 41.2 & 40.3 & 38.0 \\
\hline Months in employment in the past & 84.7 & 81.3 & 85.1 & 83.9 & 69.7 \\
\hline
\end{tabular}


Table B.1: Descriptive statistics (continued-2)

\begin{tabular}{|c|c|c|c|c|c|}
\hline & $\begin{array}{l}\text { Nonpar- } \\
\text { ticipation }\end{array}$ & $\begin{array}{l}\text { Practice } \\
\text { firm }\end{array}$ & $\begin{array}{c}\text { Short } \\
\text { training }\end{array}$ & $\begin{array}{l}\text { Long } \\
\text { training }\end{array}$ & Retraining \\
\hline Number of unemployment spells in last 2 years & 1.2 & 1.3 & 1.3 & 1.2 & 1.2 \\
\hline Number of unemployment spells in last 5 years & 1.7 & 1.9 & 1.7 & 1.7 & 1.6 \\
\hline Number of unemployment spells in the past & 2.4 & 2.9 & 2.5 & 2.4 & 2.4 \\
\hline Months in unemployment in last 2 years & 1.2 & 1.9 & 1.4 & 1.1 & 1.0 \\
\hline Months in unemployment in last 5 years & 4.3 & 6.0 & 4.4 & 4.0 & 4.0 \\
\hline Months in unemployment in the past & 10.2 & 13.0 & 10.6 & 8.8 & 8.7 \\
\hline Number of spells out of labour force in last 2 years & 0.6 & 0.6 & 0.5 & 0.5 & 0.5 \\
\hline Number of spells out of labour force in last 5 years & 0.9 & 1.0 & 0.9 & 0.8 & 1.1 \\
\hline Number of spells out of labour force in the past & 1.5 & 1.7 & 1.5 & 1.3 & 1.7 \\
\hline Months out of labour force in last 2 years & 3.5 & 3.0 & 2.9 & 2.7 & 3.1 \\
\hline Months out of labour force in last 5 years & 7.6 & 7.2 & 7.1 & 7.6 & 9.1 \\
\hline Months out of labour force in the past & 15.7 & 15.4 & 15.3 & 18.0 & 19.2 \\
\hline Fraction unemployed & 7.8 & 10.0 & 8.6 & 7.2 & 7.0 \\
\hline Fraction employed & 71.2 & 67.0 & 68.8 & 68.0 & 66.8 \\
\hline Fraction out of labour force & 13.1 & 12.5 & 12.5 & 13.5 & 15.9 \\
\hline Mean duration of unemployment in last 2 years & 0.5 & 0.8 & 0.6 & 0.5 & 0.5 \\
\hline Mean duration of unemployment in last 5 years & 1.5 & 2.0 & 1.5 & 1.3 & 1.3 \\
\hline Mean duration of unemployment in the past & 2.5 & 3.1 & 2.6 & 2.2 & 2.0 \\
\hline Mean duration of employment in last 2 years & 16.5 & 16.2 & 16.7 & 17.2 & 17.0 \\
\hline Mean duration of employment in last 5 years & 30.9 & 28.9 & 31.5 & 31.8 & 28.1 \\
\hline Mean duration of employment in the past & 48.3 & 42.2 & 48.9 & 49.3 & 35.9 \\
\hline Mean duration out of labour force in last 2 years & 3.0 & 2.5 & 2.5 & 2.4 & 2.7 \\
\hline Mean duration out of labour force in last 5 years & 5.2 & 4.4 & 4.7 & 5.4 & 6.0 \\
\hline Mean duration out of labour force in the past & 8.0 & 6.5 & 7.6 & 9.3 & 9.5 \\
\hline
\end{tabular}

Note: $\quad$ Sample before imposing the common support requirement. If not stated otherwise, entries are in per cent and measured at (simulated) programme start. *Refers to the last employment before (simulated) programme start. ${ }^{+}$Measured at entry into unemployment. See also note below Table 5 as well as the more extensive definition of variables. 
Table C.1: A matching protocol for the estimation of $\theta_{0}^{m, l}$

\begin{tabular}{|c|c|}
\hline Step 1 & $\begin{array}{l}\text { Specify and estimate a multinomial probit model to obtain the marginal choice probabilities (see } \\
\text { Internet-Appendix): }\left[\widehat{\mathrm{P}}_{\mathrm{N}}^{0}(\mathrm{x}), \widehat{\mathrm{P}}_{\mathrm{N}}^{1}(\mathrm{x}), \widehat{\mathrm{P}}_{\mathrm{N}}^{2}(\mathrm{x}), \widehat{\mathrm{P}}_{\mathrm{N}}^{3}(\mathrm{x}), \widehat{\mathrm{P}}_{\mathrm{N}}^{4}(\mathrm{x})\right] ; \widehat{\mathrm{P}}_{\mathrm{N}}^{1}(\mathrm{x}) \equiv \widehat{\mathrm{P}}_{\mathrm{N}}(\mathrm{S}=\mathrm{l} \mid \mathrm{X}=\mathrm{x})\end{array}$ \\
\hline Step 2 & $\begin{array}{l}\text { Restrict sample to common support: Delete all observations with probabilities larger than the smallest } \\
\text { maximum and smaller than the largest minimum of all subsamples defined by S. }\end{array}$ \\
\hline Step 3 & 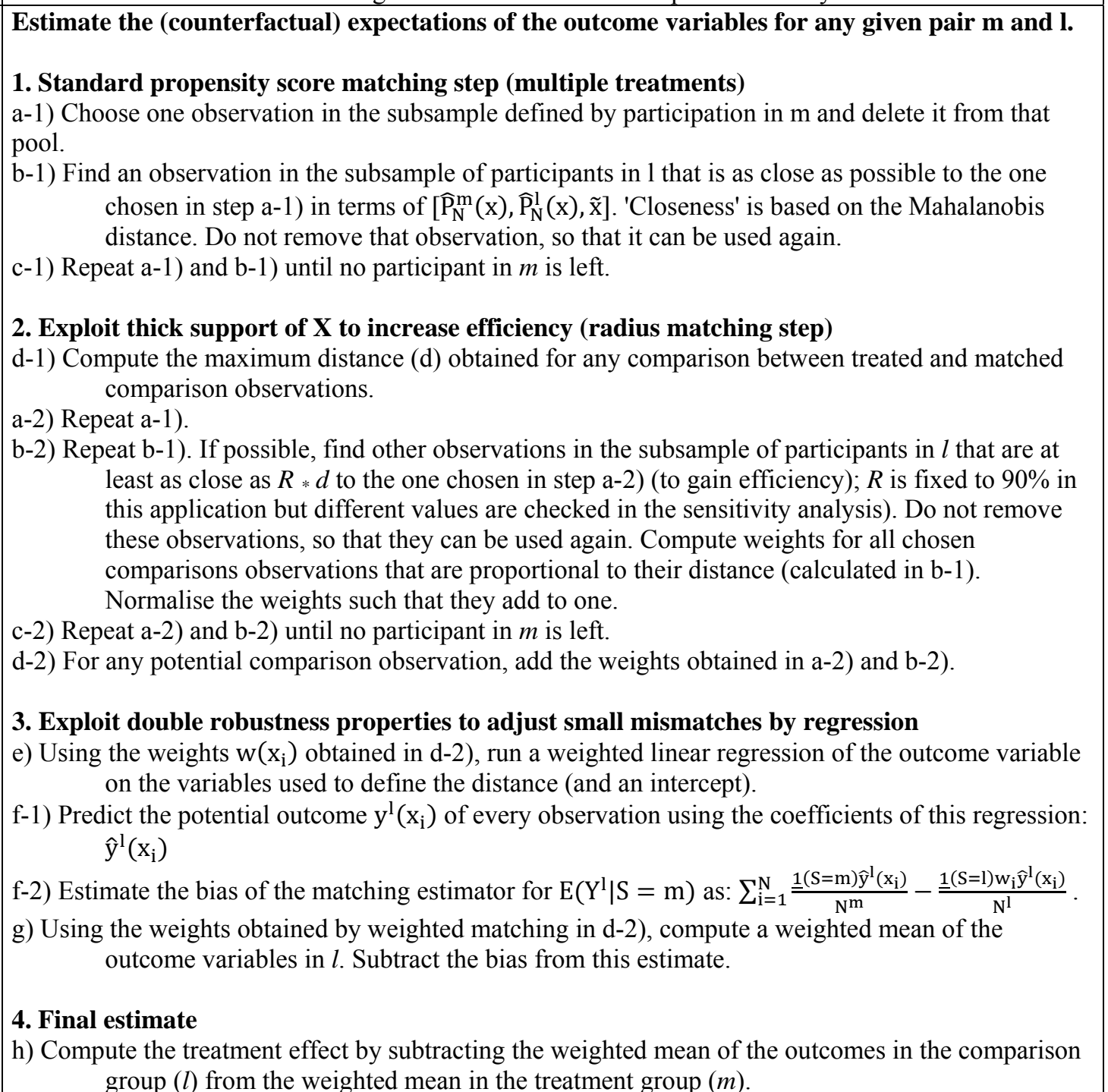 \\
\hline Step 4 & Repeat Step 3 for all combinations of $m$ and $l$. \\
\hline Note: & Lechner (2001) suggests an estimator of the asymptotic \\
\hline
\end{tabular}




\section{Figures}

Figure 1: Distribution of the planned programme duration

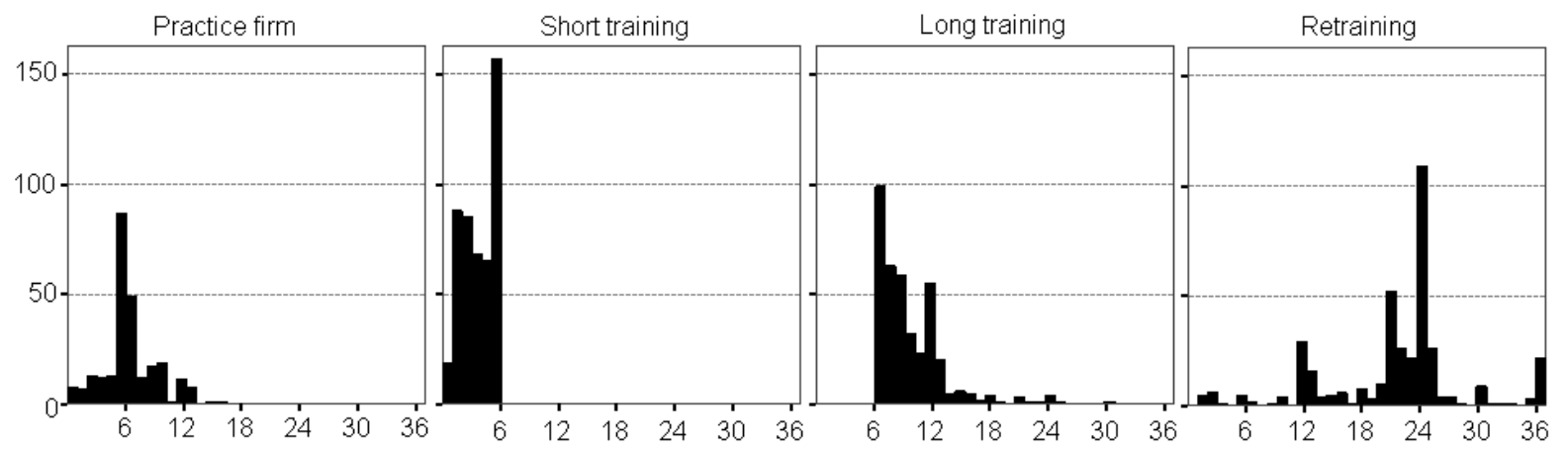

Note: Horizontal axis: planned duration of a programme determined before programme start in months. 
Figure 2: Employment and unemployment rates by participation status
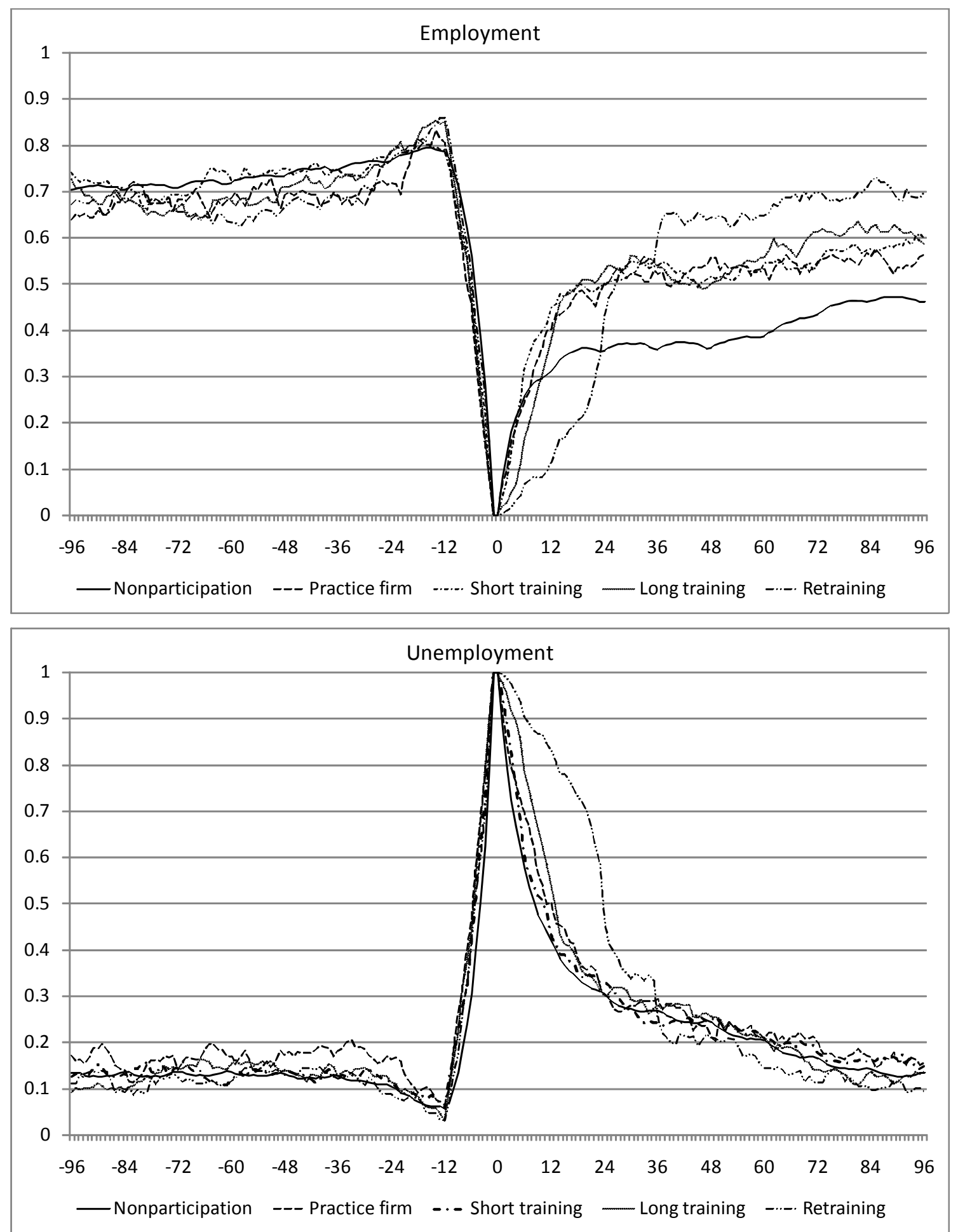

Note: Horizontal axis: months relative to programme start (0); negative: before, positive: after programme start. The number of observations before programme start decreases with increasing distance to programme start. 
Figure 3: Dynamics of the effects $\left(\hat{\theta}_{t}^{m, l}\right)$ : Employment differences in \%-points
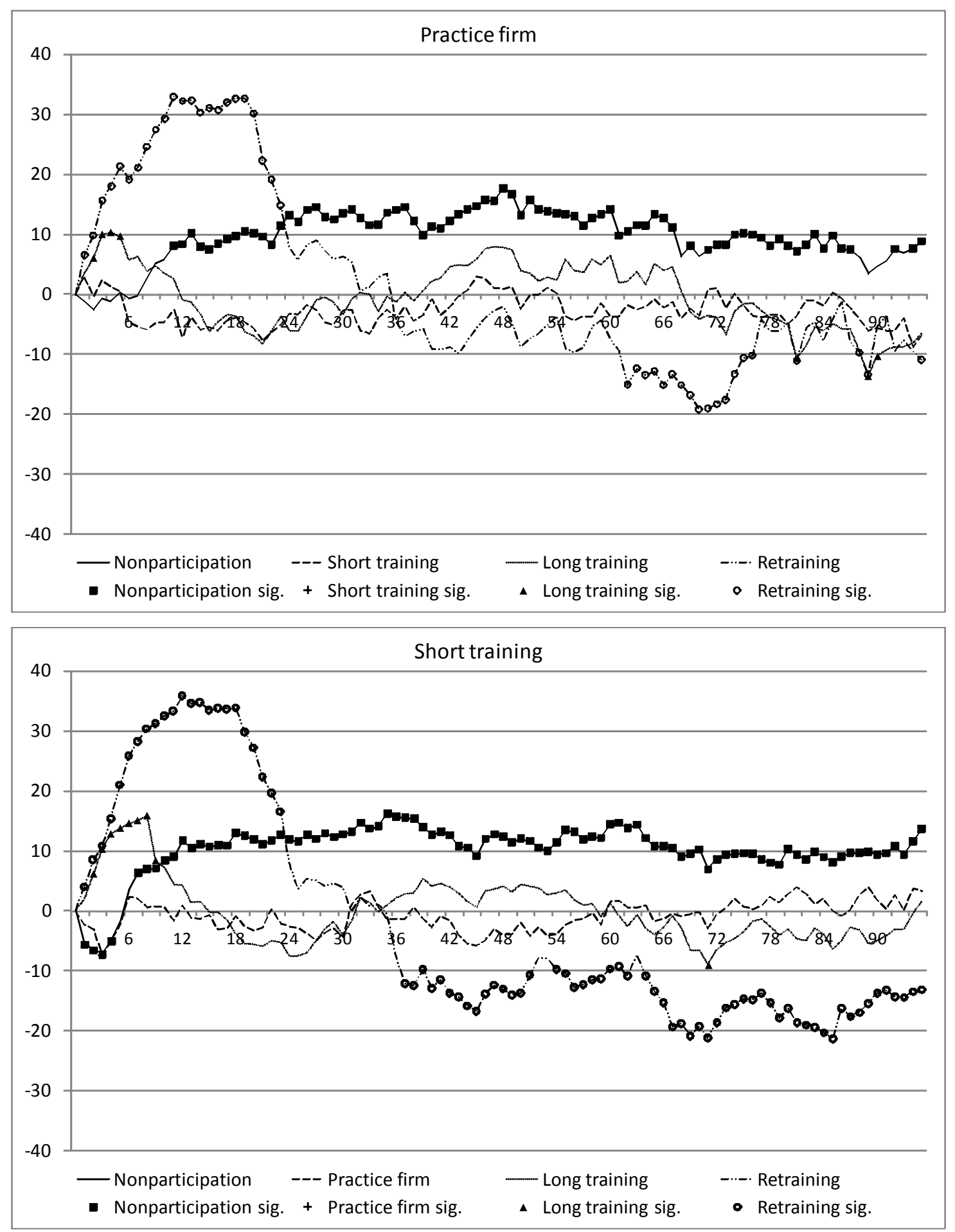

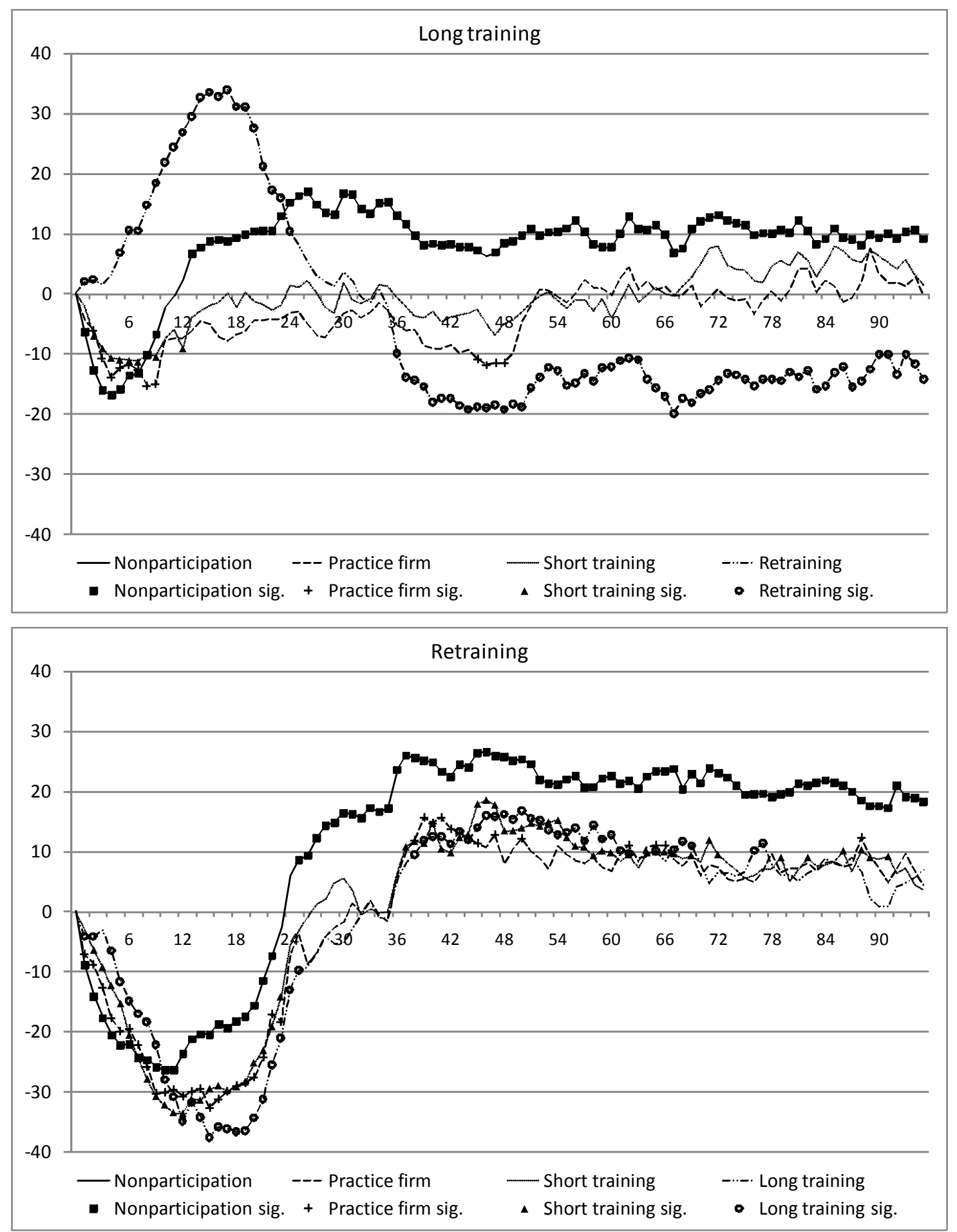

Note: Horizontal axis: months after programme start. Sig.: significant at the 5\% level (point-wise, symmetric t-test). 
Figure 4: Cumulated employment effects $\left(\underline{\hat{\theta}}_{t}^{m, l}=\sum_{\tau=1}^{t} \hat{\theta}_{\tau}^{m, l}\right)$ in months
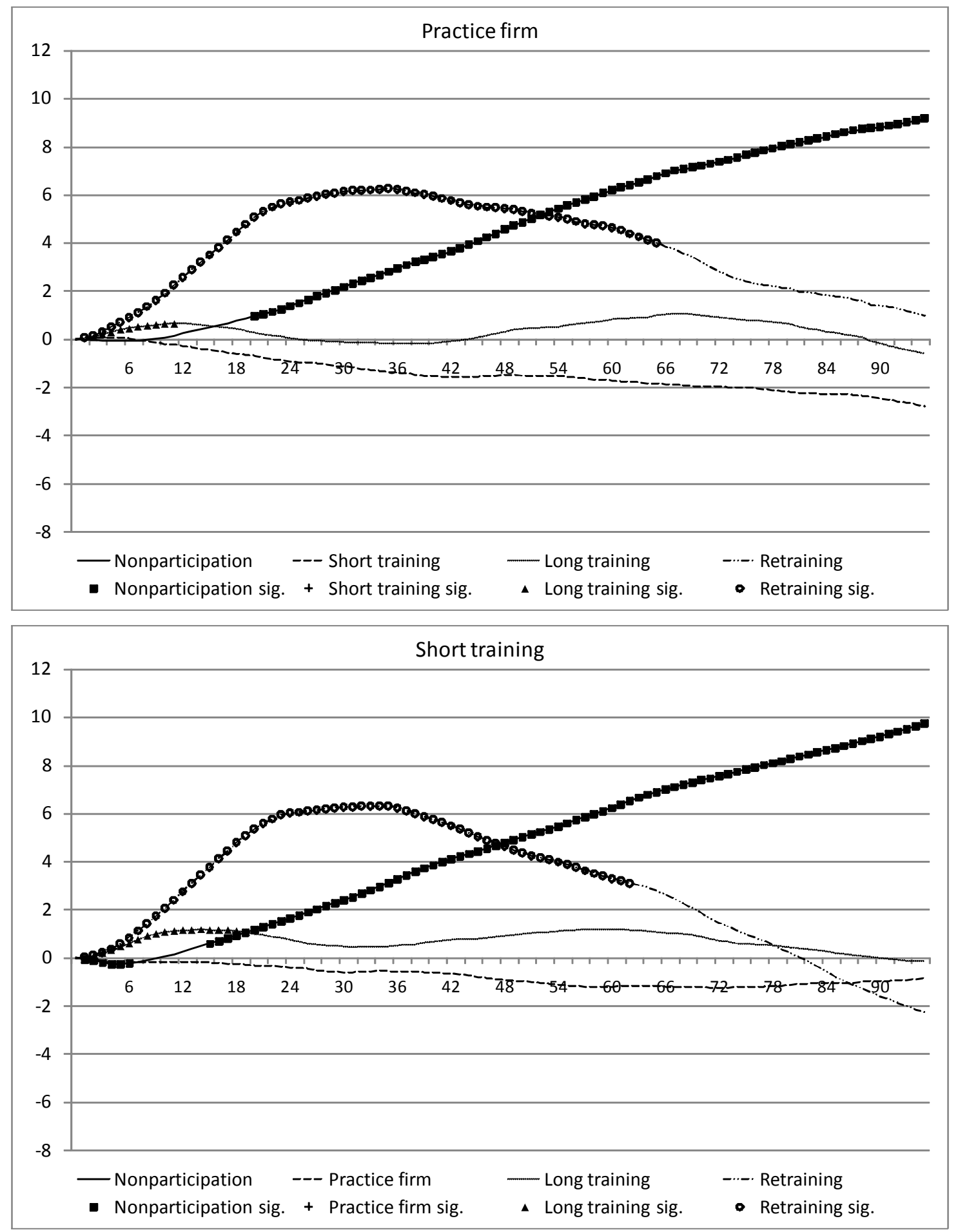

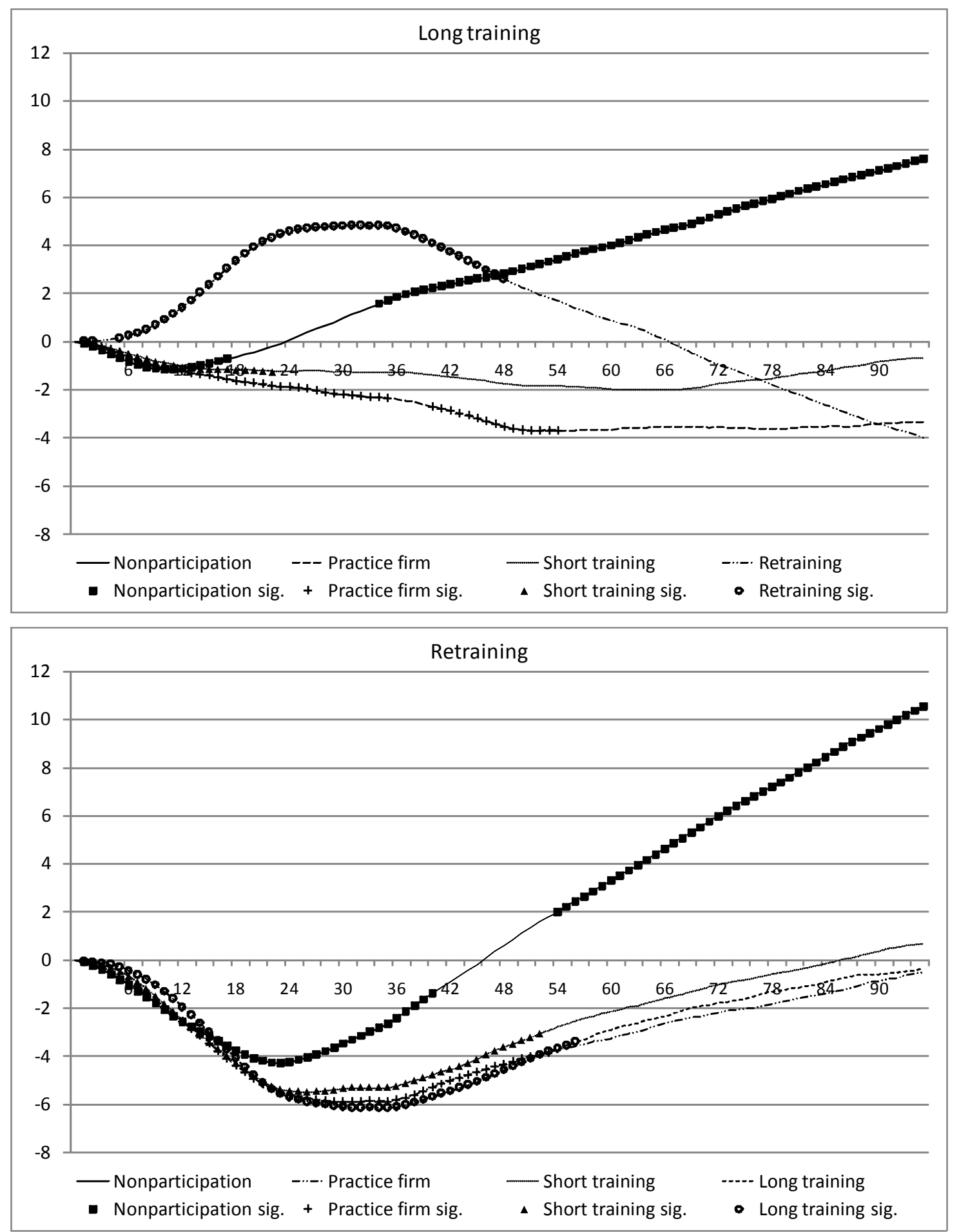

Note: Horizontal axis: months after programme start. Sig.: significant at the $5 \%$ level (point-wise, symmetric t-test). Read entry for $\underline{\hat{\theta}}_{t}^{m, l}$ as: "On average for participants in $m, t$ months after beginning participation in $m$, it increased the total time in employment compared to $l$ by $\underline{\theta}_{t}^{m, l}$ months." 
Figure B.1: Distribution of (assigned) programme start dates (frequencies in \%)

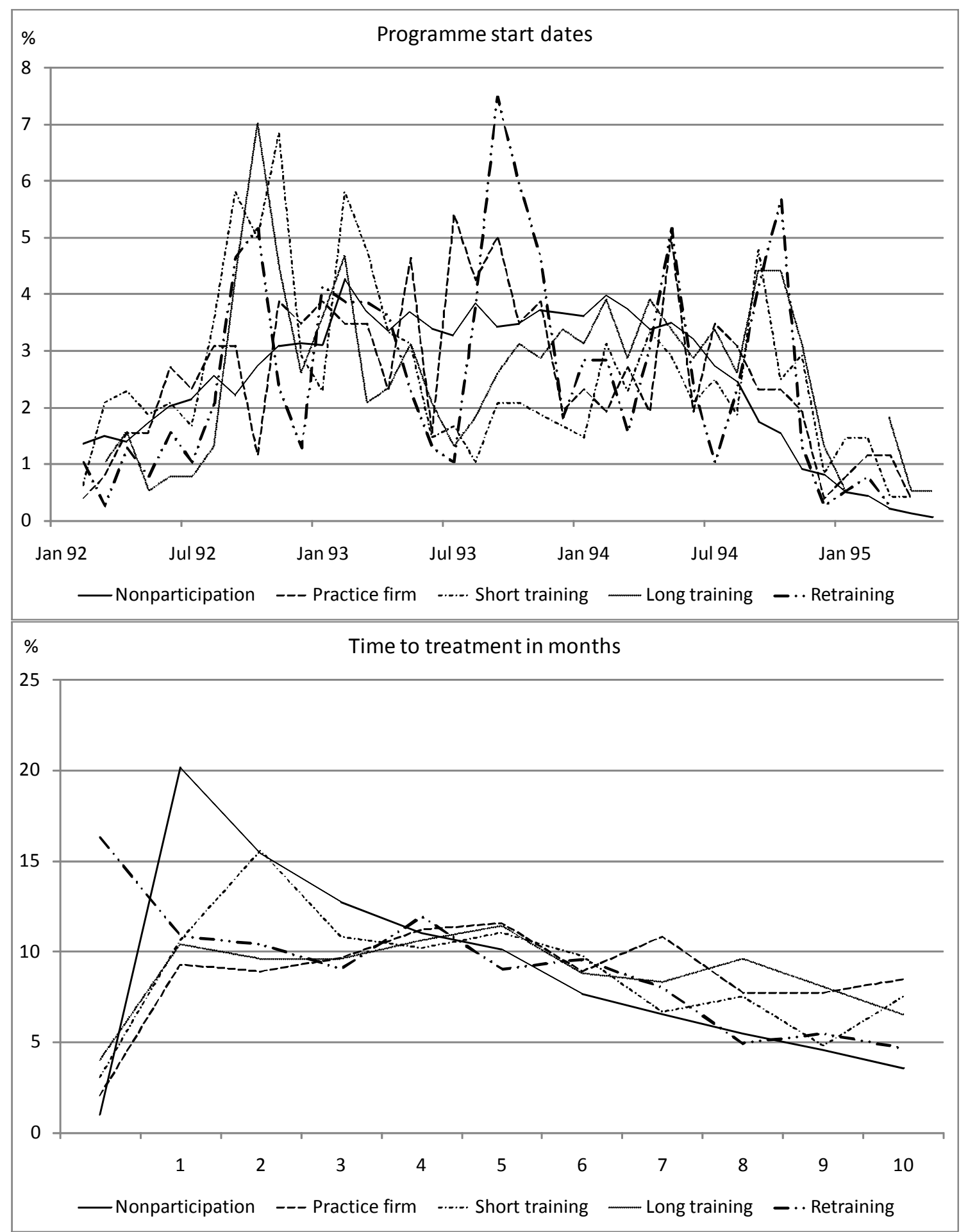

Note: Left panel: calendar month. Right panel: months from entry into unemployment to programme start. 


\title{
The Curse AND Blessing of TrAining THE
}

\author{
UNEMPLOYED IN A CHANGING ECONOMY: THE
}

\section{CASE OF EAST GERMANY AFTER UNIFICATION}

\section{- INTERNET APPENDIX -}

\author{
Michael Lechner, Ruth Miquel and Conny Wunsch* \\ SIAW \\ Swiss Institute for International Economics \\ and Applied Economic Research \\ University of St.Gallen \\ First version: May, 2005 \\ Date this version has been printed: 14 February 2006 \\ Comments are very welcome
}

Keywords: Active labour market policy, nonparametric identification, matching estimation, causal effects, programme evaluation, panel data, gender differences

\section{JEL classification: J 68}

\section{Addresses for correspondence}

Michael Lechner, Ruth Miquel, Conny Wunsch

Swiss Institute for International Economics and Applied Economic Research (SIAW), University of St. Gallen Bodanstr. 8, CH-9000 St. Gallen, Switzerland

Michael.Lechner@unisg.ch, Ruth.Miquel@unisg.ch, Conny.Wunsch@unisg.ch,www.siaw.unisg.ch/lechner

\footnotetext{
The first author has further affiliations with CEPR, London, ZEW, Mannheim, IZA, Bonn and PSI, London. Financial support from the Institut für Arbeitsmarkt- und Berufsforschung, Nuremberg, (project 6-531) is gratefully acknowledged. The data originated from a joint effort with Annette Bergemann, Bernd Fitzenberger and Stefan Speckesser to make the administrative data accessible for research. We presented the paper in seminars at the University of St. Gallen. We thank participants for helpful comments. The usual disclaimer applies. The interested reader will find additional background material for this paper (internet appendix) on our website www.siaw.unisg.ch/lechner/lmw_fuu_ost.
} 


\section{Appendix IA: Supplementary information about the data}

\section{Appendix IA.1: Original and target professions of retrainees 1993-1994}

Table IA.1: Transitions between original and target professions of retrainees 1993-1994

\begin{tabular}{|c|c|c|c|c|c|c|c|c|c|c|c|c|c|c|}
\hline & \multicolumn{12}{|c|}{ Original profession } & & \\
\hline & None & 1 & 2 & 3 & 4 & 5 & 6 & 7 & 8 & 9 & 10 & $\%$ of all & \multicolumn{2}{|c|}{ UE rate } \\
\hline Target profession & \multicolumn{12}{|c|}{ Men } & 1994 & 2002 \\
\hline 0 No information & 11 & 4 & 2 & - & - & - & 15 & - & - & - & - & 4 & & \\
\hline 1 Agriculture, gardening, forestry, mining & 6 & 4 & 2 & - & - & - & - & - & - & - & - & 2 & 24 & 31 \\
\hline 2 Metal production/processing, mechanics & 3 & - & 4 & - & - & - & - & - & - & - & - & 2 & 15 & 19 \\
\hline 3 Textile/leather manufacturing & - & - & - & - & - & - & - & - & - & - & - & - & 59 & 42 \\
\hline 4 Food and nuitrition & - & & 1 & - & - & . & - & 4 & - & - & - & 1 & 33 & 30 \\
\hline 5 Construction & 25 & 24 & 12 & 40 & 14 & 29 & 8 & 17 & - & - & 23 & 18 & 6 & 33 \\
\hline 6 Construction related handcraft & 39 & 56 & 62 & 60 & 86 & 36 & 54 & 52 & 100 & - & 42 & 53 & 9 & 28 \\
\hline 7 Technical profess., other manufacturing & 3 & - & 5 & - & - & 7 & 8 & 5 & - & - & 8 & 4 & 16 & 19 \\
\hline 8 Office work & 6 & - & 5 & - & - & 14 & 8 & 14 & - & 50 & 8 & 7 & 16 & 20 \\
\hline 9 Health/social services, education & - & 8 & 1 & - & - & - & - & 3 & - & 25 & 8 & 3 & 9 & 9 \\
\hline 10 Other services & 8 & 4 & 6 & - & - & 14 & 8 & 3 & - & 25 & 12 & 7 & 22 & 28 \\
\hline \multirow[t]{2}{*}{$\%$ of all } & 14 & 10 & 34 & 2 & 3 & 6 & 5 & 15 & 1 & 2 & 10 & 100 & 15 & 22 \\
\hline & \multicolumn{12}{|c|}{ Women } & \multicolumn{2}{|c|}{ UE rate } \\
\hline 0 No information & - & - & 10 & 6 & - & - & - & 5 & 16 & 13 & 13 & 8 & & \\
\hline 1 Agriculture, gardening, forestry, mining & 7 & 26 & 30 & 3 & 33 & - & 17 & 9 & - & - & 4 & 9 & 24 & 31 \\
\hline 2 Metal production/processing, mechanics & - & 4 & - & - & - & - & - & - & - & - & - & 1 & 15 & 19 \\
\hline 3 Textile/leather manufacturing & - & - & - & - & - & - & - & - & - & - & - & - & 59 & 42 \\
\hline 4 Food and nuitrition & 14 & 9 & & 6 & 17 & - & - & 5 & - & - & - & 4 & 33 & 30 \\
\hline 5 Construction & - & - & - & - & - & - & - & - & - & - & - & - & 6 & 33 \\
\hline 6 Construction related handcraft & - & 9 & 20 & 6 & 17 & - & - & - & - & - & 13 & 5 & 9 & 28 \\
\hline 7 Technical profess., other manufacturing & 7 & - & 10 & 3 & - & 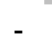 & 17 & 18 & 3 & - & - & 5 & 16 & 19 \\
\hline 8 Office work & 43 & 22 & 10 & 36 & 33 & - & 33 & 46 & 61 & 21 & 35 & 36 & 16 & 20 \\
\hline 9 Health/social services, education & - & 17 & - & 16 & - & 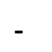 & 17 & 9 & 13 & 63 & 17 & 18 & 9 & 9 \\
\hline 10 Other services & 29 & 13 & 20 & 23 & - & - & 17 & 9 & 7 & 4 & 17 & 14 & 22 & 28 \\
\hline$\%$ of all & 7 & 12 & 5 & 16 & 3 & - & 3 & 12 & 16 & 13 & 12 & 100 & 15 & 22 \\
\hline \multicolumn{15}{|c|}{ Source: Own calculations on the basis of our evaluation sample (see Section 3). UE rates: BA (1992-2004). } \\
\hline - 5 . & & & & & & & & & & & & & & \\
\hline
\end{tabular}




\section{Appendix IA.2: Additional descriptive statistics}

Figure IA.2: Month of beginning of first UE spell between 1993 and 1994

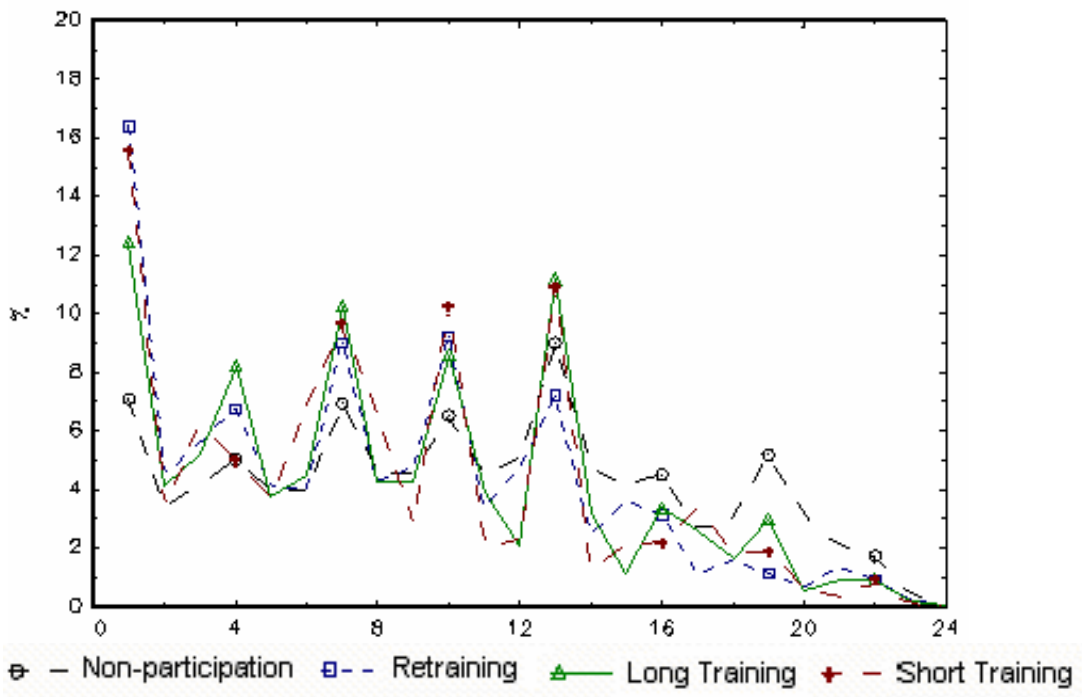

Note: Month 1 correponds to January 1993. 


\section{Appendix IB: Common support and match quality}

\section{Appendix IB.1: Common support}

As proposed, discussed and applied in Lechner (2001, 2002a, b) we base the common support requirement on the marginal choice probabilities (conditional on $X$ ) for all alternatives under consideration. By doing so, we ensure that all effects are estimated for the same underlying support. Table IB.1a shows the minima and the maxima of the estimated probabilities. Figure IB.1 displays the distribution of the estimated probabilities for all subsamples defined by participation status before and after imposing common support. In addition, Table IB.1c shows the mean of all variables in the selected and excluded subsample for all groups of participants. Tables IB.1b and IB.1d display the loss of observations as a result of imposing the common support criterion for the full sample and the subsample analysis, respectively.

Table IB.1a: Minima and maxima of $\left[\hat{P}_{N}^{1}(x), \hat{P}_{N}^{2}(x), \hat{P}_{N}^{3}(x), \hat{P}_{N}^{4}(x)\right]$ in subsamples

\begin{tabular}{ccccc}
\hline \hline Subsamples & $\hat{P}_{N}^{1}(x)$ & $\hat{P}_{N}^{2}(x)$ & $\hat{P}_{N}^{3}(x)$ & $\hat{P}_{N}^{4}(x)$ \\
& \multicolumn{5}{c}{ Maximum in subsample } \\
Nonparticipation & 100 & 52.33 & 63.45 & 84.05 \\
Short training & 99.42 & 59.90 & 71.99 & 70.19 \\
Long training & 99.69 & 60.20 & 73.79 & 66.08 \\
Retraining & 98.19 & 55.15 & 67.94 & 88.02 \\
\hline Minimum of maxima & 98.19 & 52.33 & 63.45 & 66.08 \\
\hline Nonparticipation & 0.04 & 0.0 & 0.0 \\
Short training & 0.0 & 0.04 & 0.0 & 0.0 \\
Long training & 0.04 & 0.0 & 0.19 & 0.01 \\
Retraining & 0.02 & 0.03 & 0.06 & 0.19 \\
\hline Maximum of minima & 0.04 & 0.04 & 0.19 & 0.19 \\
\hline
\end{tabular}

Note: Estimated probabilities in \%. 
Figure IB.1: Distribution of $\left[\hat{P}_{N}^{1}(x), \hat{P}_{N}^{2}(x), \hat{P}_{N}^{3}(x), \hat{P}_{N}^{4}(x)\right]$ in the respective subsamples before and after imposing the common support requirement
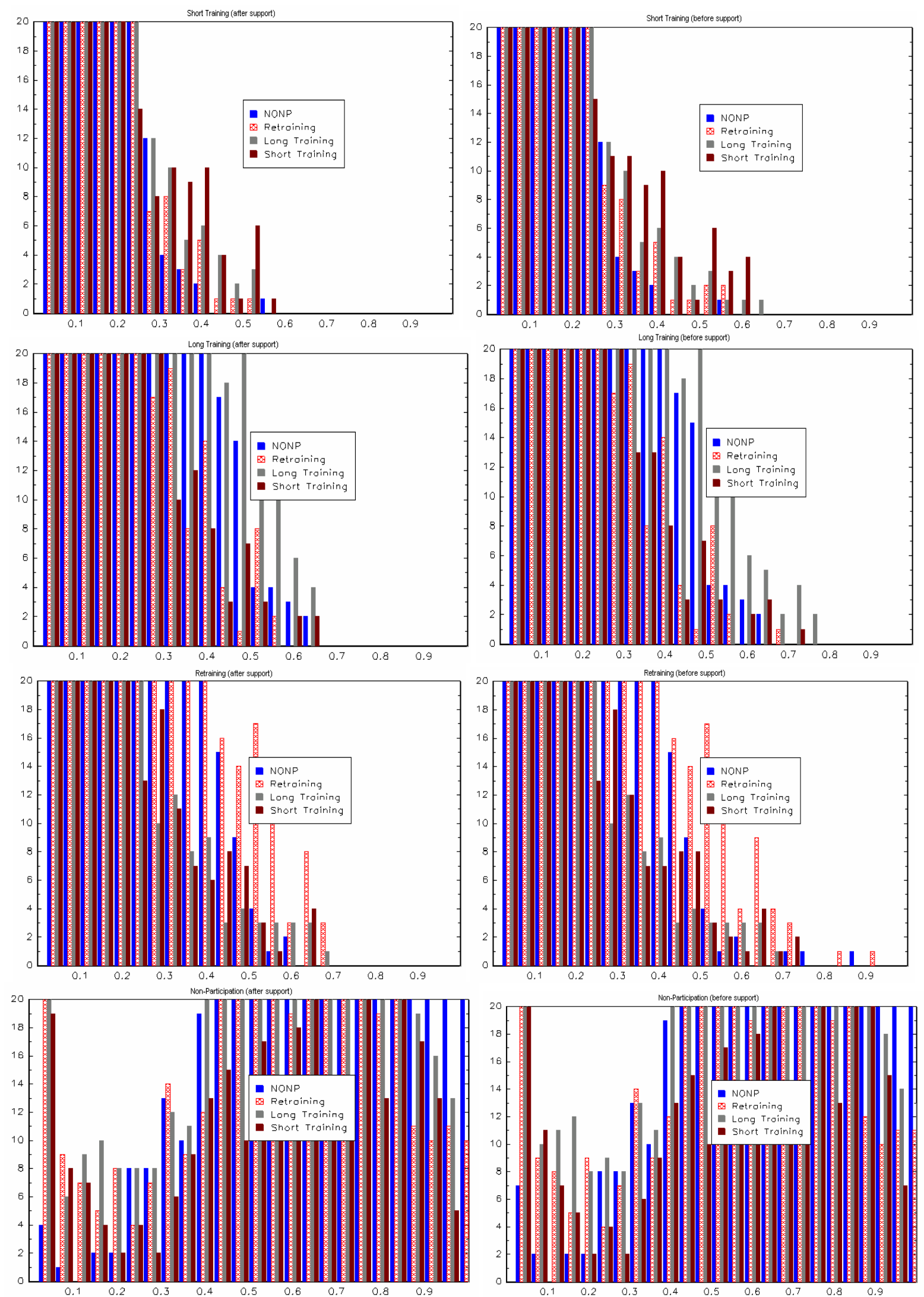

Note: Figures show the actual number of observations in deciles before (right panel) and after (left panel) imposing the common support requirement. 
Table IB.1b: Loss of observations due to imposition of the common support criterion

\begin{tabular}{|l|c|c|c|c|}
\hline \hline & Nonparticipation & Short training & Long training & Retraining \\
\hline Observations before & 4604 & 321 & 538 & 445 \\
\hline Observations after & 3542 & 292 & 502 & 429 \\
\hline Percent deleted & 23.1 & 9.0 & 6.7 & 3.6 \\
\hline
\end{tabular}

Table IB.1c: Comparison of means of selected variables in the subsample used for matching and the subsample not used for matching because of insufficient overlap

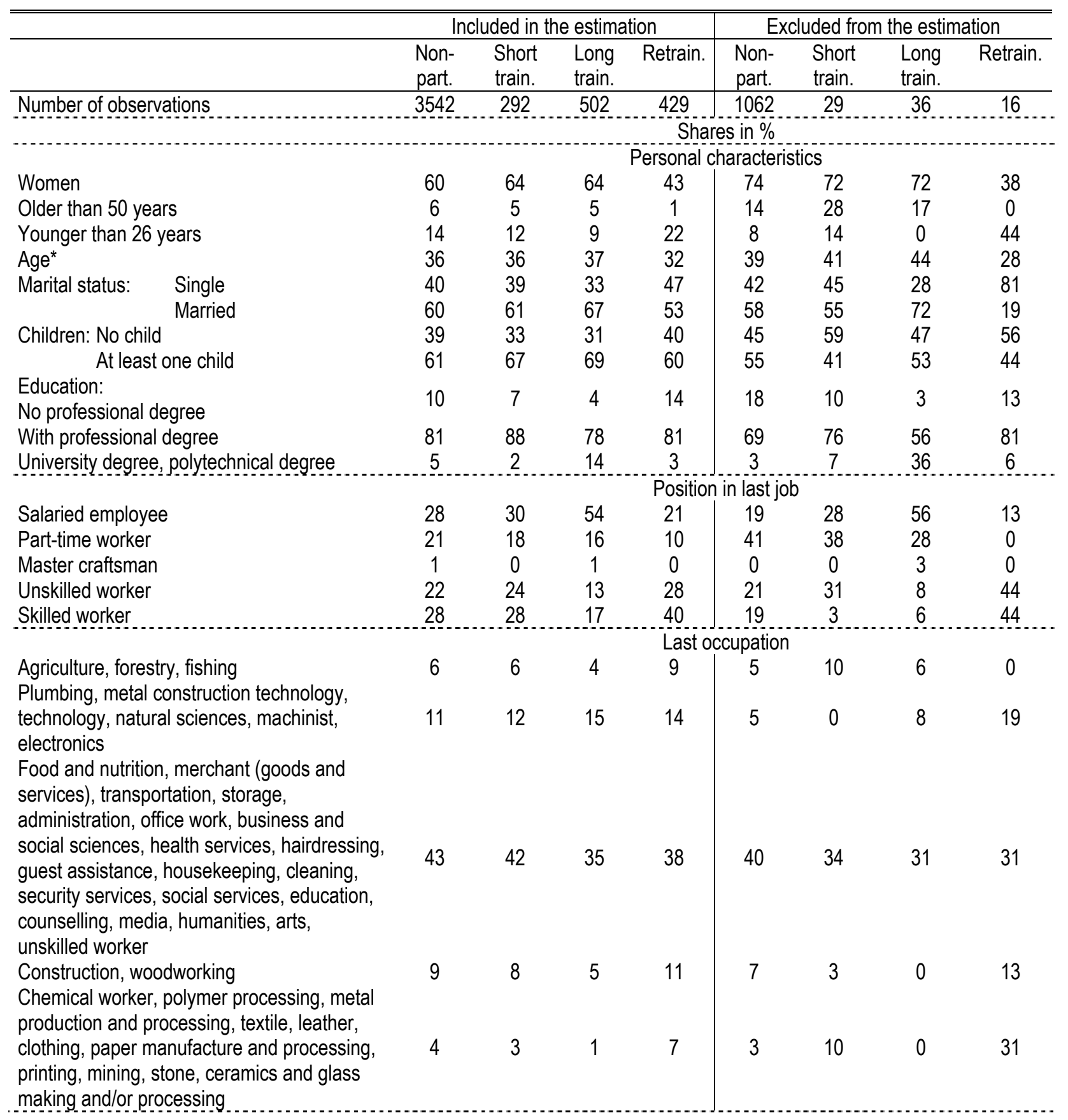

Table IB.1c to be continued 
Table IB.1c: Comparison of means of selected variables (continued-1)

\begin{tabular}{|c|c|c|c|c|c|c|c|c|}
\hline & \multicolumn{4}{|c|}{ Included in the estimation } & \multicolumn{4}{|c|}{ Excluded from the estimation } \\
\hline & $\begin{array}{l}\text { Non- } \\
\text { part. }\end{array}$ & $\begin{array}{l}\text { Short } \\
\text { train. }\end{array}$ & $\begin{array}{l}\text { Long } \\
\text { train. }\end{array}$ & Retrain. & $\begin{array}{l}\text { Non- } \\
\text { part. }\end{array}$ & $\begin{array}{l}\text { Short } \\
\text { train. }\end{array}$ & $\begin{array}{l}\text { Long } \\
\text { train. }\end{array}$ & Retrain. \\
\hline & \multicolumn{8}{|c|}{ Industrial sector } \\
\hline Construction & 8 & 6 & 5 & 8 & 7 & 3 & 0 & 6 \\
\hline $\begin{array}{l}\text { Commerce, banking, insurance, local and } \\
\text { regional authorities, social insurance, non- } \\
\text { profit organisations, private household, } \\
\text { transportation, telecommunications, other } \\
\text { services }\end{array}$ & 59 & 63 & 61 & 54 & 54 & 72 & 47 & 44 \\
\hline \multirow{2}{*}{$\begin{array}{l}\text { Agriculture, forestry, fishing } \\
\text { Energy and supply industry, mining, } \\
\text { manufacturing (without construction) }\end{array}$} & 2 & 2 & 1 & 3 & 3 & 0 & 0 & 0 \\
\hline & 27 & 26 & 29 & 31 & 29 & 21 & 44 & 50 \\
\hline & \multicolumn{8}{|c|}{ Last monthly earnings } \\
\hline Salary in Euros* & 2001 & 2099 & 2361 & 2227 & 1354 & 1654 & 2261 & 2534 \\
\hline No information & 17 & 12 & 13 & 9 & 33 & 14 & 22 & 0 \\
\hline $1278>$ salary & 53 & 53 & 42 & 52 & 56 & 72 & 36 & 56 \\
\hline $1278 \leq$ salary $<2556$ & 29 & 34 & 42 & 39 & 11 & 17 & 39 & 44 \\
\hline $2556 \geq$ salary & 2 & 0 & 3 & 0 & 1 & 0 & 3 & 0 \\
\hline \multicolumn{9}{|c|}{ Remaining unemployment (UE) benefits claim at the end of the last unemployment spell before entry in the programme } \\
\hline Remaining UE benefits claim (in months)* & 2.6 & 2.3 & 2.4 & 2.4 & 1 & 0.3 & 0.7 & 1.8 \\
\hline No information or no claim & 49 & 55 & 53 & 52 & 79 & 93 & 83 & 75 \\
\hline$\leq 6$ months & 36 & 33 & 34 & 34 & 15 & 3 & 11 & 6 \\
\hline$\leq 1$ year & 50 & 44 & 46 & 47 & 20 & 7 & 17 & 25 \\
\hline$\leq 18$ months & 51 & 45 & 47 & 48 & 20 & 7 & 17 & 25 \\
\hline \multicolumn{9}{|c|}{ Legal UE benefits claim at the beginning of the last unemployment spell before the programme } \\
\hline Legal claim* (in months) & 6.4 & 5.4 & 5.9 & 5.6 & 3.4 & 2.9 & 3.5 & 2.5 \\
\hline No information & 16 & 25 & 21 & 21 & 55 & 55 & 31 & 63 \\
\hline No claim & 9 & 11 & 9 & 7 & 6 & 3 & 17 & 0 \\
\hline$\leq 6$ months & 17 & 15 & 18 & 20 & 11 & 17 & 31 & 13 \\
\hline$\leq 1$ year & 71 & 63 & 66 & 71 & 36 & 41 & 53 & 38 \\
\hline$\leq 18$ months & 74 & 64 & 70 & 72 & 38 & 41 & 53 & 38 \\
\hline \multicolumn{9}{|c|}{ Unemployment benefits or assistance in the month before beginning of the programme } \\
\hline UE benefits & 83 & 75 & 79 & 79 & 45 & 45 & 69 & 38 \\
\hline UE assistance & 17 & 25 & 21 & 21 & 55 & 55 & 31 & 63 \\
\hline \multicolumn{9}{|c|}{ Various historical un-/ out-of/employment information before the "first unemployment period" } \\
\hline Months of last employment spell ${ }^{*}$ & 16.7 & 15.2 & 16.8 & 16.2 & 12.6 & 12.2 & 13.5 & 20.4 \\
\hline Proportion of employment months (in \%)* & 68.7 & 72.6 & 78.0 & 77.9 & 45.8 & 67.8 & 64.0 & 67.7 \\
\hline Proportion of out-of-labour months (in \%)* & 11.1 & 10.1 & 9.0 & 10.0 & 13.6 & 1.6 & 6.5 & 7.5 \\
\hline Proportion of UE months (in \%) & 10.5 & 9.6 & 7.3 & 7.7 & 21.9 & 13.8 & 14.8 & 4.3 \\
\hline $\begin{array}{l}\text { \# of programs up to } 2 \text { years before the UE } \\
\text { period* }\end{array}$ & 0.14 & 0.16 & 0.10 & 0.10 & 0.32 & 0.28 & 0.25 & 0.38 \\
\hline $\begin{array}{l}\text { \# of programs up to } 5 \text { years before the UE } \\
\text { period* }^{*}\end{array}$ & 0.17 & 0.18 & 0.11 & 0.11 & 0.38 & 0.28 & 0.25 & 0.44 \\
\hline $\begin{array}{l}\text { Mean duration of UE spells up to } 2 \text { years } \\
\text { before the UEP* }\end{array}$ & 1.65 & 1.92 & 1.30 & 1.37 & 3.44 & 2.09 & 2.32 & 1.19 \\
\hline $\begin{array}{l}\text { Mean duration of UE spells up to } 5 \text { years } \\
\text { before UEP* }\end{array}$ & 2.47 & 2.21 & 1.65 & 1.75 & 5.09 & 2.53 & 3.65 & 1.25 \\
\hline $\begin{array}{l}\text { Mean duration of employment spells up to } 2 \\
\text { years before UEP* }\end{array}$ & 7.99 & 9.33 & 9.99 & 9.83 & 4.90 & 10.17 & 9.01 & 8.94 \\
\hline $\begin{array}{l}\text { Mean duration of employment spells up to } 5 \\
\text { years before UEP* }\end{array}$ & 14.09 & 13.54 & 15.38 & 14.91 & 9.62 & 12.21 & 12.78 & 9.88 \\
\hline $\begin{array}{l}\text { Mean duration of out-of-labour spells up to } 2 \\
\text { years before UEP* }\end{array}$ & 1.78 & 1.72 & 1.67 & 1.71 & 2.19 & 0.38 & 1.03 & 1.56 \\
\hline $\begin{array}{l}\text { Mean duration of out-of-labour spells up to } 5 \\
\text { years before UEP* }\end{array}$ & 2.90 & 2.49 & 2.16 & 2.30 & 3.33 & 0.45 & 1.19 & 1.50 \\
\hline
\end{tabular}


Table IB.1c: Comparison of means of selected variables (continued-2)

\begin{tabular}{|c|c|c|c|c|c|c|c|c|}
\hline & \multicolumn{4}{|c|}{ Included in the estimation } & \multicolumn{4}{|c|}{ Excluded from the estimation } \\
\hline & $\begin{array}{l}\text { Non- } \\
\text { part. }\end{array}$ & $\begin{array}{l}\text { Short } \\
\text { train. }\end{array}$ & $\begin{array}{l}\text { Long } \\
\text { train. }\end{array}$ & Retrain. & $\begin{array}{l}\text { Non- } \\
\text { part. }\end{array}$ & $\begin{array}{l}\text { Short } \\
\text { train. }\end{array}$ & $\begin{array}{l}\text { Long } \\
\text { train. }\end{array}$ & Retrain. \\
\hline $\begin{array}{l}\text { Total months in all programmes up to } 2 \text { years } \\
\text { before the UEP* }\end{array}$ & 1.65 & 1.35 & 0.77 & 0.60 & 3.62 & 2.59 & 2.44 & 3.56 \\
\hline $\begin{array}{l}\text { Total months in all programmes up to } 5 \text { years } \\
\text { before the UEP* }\end{array}$ & 1.89 & 1.57 & 0.84 & 0.65 & 4.18 & 2.59 & 2.44 & 4.06 \\
\hline \multicolumn{9}{|c|}{ Various un-lemployment information from the "first unemployment period" } \\
\hline Duration of the "first UE spell"* & 7.0 & 7.6 & 7.2 & 6.3 & 9.7 & 12.5 & 10.7 & 8.8 \\
\hline Duration of last UE spell before programme* & 6.2 & 6.3 & 6.1 & 5.2 & 8.2 & 8.3 & 7.7 & 4.2 \\
\hline $\begin{array}{l}\text { Time since beginning of last UE spell (before } \\
\text { the prog.) even if other state between UE and } \\
\text { prog.* }\end{array}$ & 6.2 & 7.7 & 7.3 & 6.4 & 8.2 & 13.1 & 9.8 & 10.8 \\
\hline Time between the prog. and last job* & 12.5 & 12.1 & 11.4 & 10.0 & 21.5 & 19.9 & 14.8 & 16.5 \\
\hline 3 months $\geq$ time between prog. and last job & 18 & 18 & 16 & 20 & 8 & 0 & 8 & 6 \\
\hline 6 months $\geq$ time between prog. and last job & 39 & 38 & 34 & 41 & 18 & 7 & 31 & 19 \\
\hline 12 months $\geq$ time between prog. and last job & 65 & 64 & 69 & 73 & 32 & 28 & 53 & 31 \\
\hline 24 months $\geq$ time between prog. and last job & 84 & 87 & 88 & 93 & 56 & 69 & 78 & 81 \\
\hline $\begin{array}{l}\text { Transition in } 6 \text { months before programme: } \\
U E \rightarrow U E\end{array}$ & 58 & 63 & 64 & 60 & 65 & 90 & 72 & 69 \\
\hline $\begin{array}{l}\text { Transition in } 6 \text { months before the programme: } \\
\text { empl. } \rightarrow \text { UE }\end{array}$ & 30 & 30 & 29 & 31 & 14 & 3 & 25 & 6 \\
\hline $\begin{array}{l}\text { Transition in } 6 \text { months before programme: } \\
\text { out } \rightarrow \text { UE }\end{array}$ & 8 & 4 & 5 & 6 & 13 & 7 & 3 & 19 \\
\hline $\begin{array}{l}\text { Transition in } 6 \text { months before programme: } \\
\text { prog. } \rightarrow \text { UE }\end{array}$ & 4 & 3 & 1 & 3 & 8 & 0 & 0 & 6 \\
\hline $\begin{array}{l}\text { Number of prog. in year before actual } \\
\text { programme* }\end{array}$ & 0.09 & 0.05 & 0.02 & 0.05 & 0.17 & 0.03 & 0.03 & 0.13 \\
\hline $\begin{array}{l}\text { Number of prog.'s in } 6 \text { months before actual } \\
\text { programme* }\end{array}$ & 0.04 & 0.03 & 0.01 & 0.03 & 0.09 & 0 & 0 & 0.06 \\
\hline & \multicolumn{8}{|c|}{ Regional information } \\
\hline Big City & 16 & 18 & 15 & 13 & 20 & 14 & 8 & 19 \\
\hline Net migration per 1000 inhabitants & 12.4 & 13.5 & 9.5 & 9.9 & 20.0 & 12.2 & 13.0 & 7.7 \\
\hline $\begin{array}{l}\text { Inhabitants below age } 15 \text { in \% of the } 15-65 \\
\text { year olds }\end{array}$ & 20.2 & 20.1 & 21.0 & 21.5 & 17.0 & 20.8 & 20.8 & 21.3 \\
\hline $\begin{array}{l}\text { Inhabitants above age } 65 \text { in } \% \text { of the } 15-65 \\
\text { year olds }\end{array}$ & 19.0 & 19.0 & 19.7 & 20.1 & 15.9 & 20.2 & 19.9 & 19.6 \\
\hline $\begin{array}{l}\text { Inhabitants of age } 15-65 \text { in } \% \text { of all } \\
\text { inhabitants }\end{array}$ & 60.9 & 61.5 & 63.3 & 63.6 & 53.5 & 63.5 & 62.1 & 64.2 \\
\hline $\begin{array}{l}\text { Inhabitants above age } 75 \text { in } \% \text { of all } \\
\text { inhabitants }\end{array}$ & 4.6 & 4.6 & 4.9 & 5.1 & 3.1 & 5.2 & 4.9 & 5.0 \\
\hline $\begin{array}{l}\text { Recipients of social assistance per } 1000 \\
\text { inhabitants }\end{array}$ & 15.5 & 16.0 & 16.1 & 16.5 & 13.6 & 14.9 & 14.5 & 14.8 \\
\hline $\begin{array}{l}\text { Fraction of non-German nationals among } \\
\text { recipients of social assistance }^{a}\end{array}$ & 10.5 & 8.4 & 9.2 & 10.0 & 10.6 & 5.2 & 17.4 & 8.4 \\
\hline Net migration per 1000 insured employees* & 53.0 & 66.8 & 38.5 & 1.6 & 158 & -93 & -0.1 & 58 \\
\hline $\begin{array}{l}\text { Gross value added - fraction agriculture and } \\
\text { forestry }^{*}\end{array}$ & 0.9 & 0.8 & 1.1 & 1.4 & -0.1 & 0.8 & 1.1 & 1.1 \\
\hline Gross value added - fraction other services* & 43.2 & 43.7 & 45.6 & 44.9 & 38.4 & 48.4 & 42.9 & 44.4 \\
\hline Gross value added - fraction manufacturing* & 31.7 & 31.8 & 32.3 & 33.4 & 26.7 & 30.5 & 33.8 & 34.0 \\
\hline $\begin{array}{l}\text { Gross value added - fraction commerce and } \\
\text { transportations* }\end{array}$ & 10.5 & 10.8 & 11.2 & 11.5 & 8.3 & 11.0 & 10.9 & 12.0 \\
\hline Gross value added in DM per inhabitant* & 21749 & 22515 & 22670 & 22103 & 19758 & 21314 & 20720 & 24377 \\
\hline Tax revenue in DM per inhabitant & 163 & 166 & 160 & 172 & 144 & 145 & 166 & 242 \\
\hline Rural areas & 21 & 15 & 22 & 24 & 19 & 17 & 19 & 19 \\
\hline $\begin{array}{l}\text { Core cities and highly concentrated districts } \\
\text { in agglomerations }\end{array}$ & 13 & 13 & 15 & 12 & 13 & 24 & 6 & 31 \\
\hline
\end{tabular}


Table IB.1c: Comparison of means of selected variables (continued-3)

\begin{tabular}{|c|c|c|c|c|c|c|c|c|}
\hline & \multicolumn{4}{|c|}{ Included in the estimation } & \multicolumn{4}{|c|}{ Excluded from the estimation } \\
\hline & $\begin{array}{l}\text { Non- } \\
\text { part. }\end{array}$ & $\begin{array}{l}\text { Short } \\
\text { train. }\end{array}$ & $\begin{array}{l}\text { Long } \\
\text { train. }\end{array}$ & Retrain. & $\begin{array}{l}\text { Non- } \\
\text { part. }\end{array}$ & $\begin{array}{l}\text { Short } \\
\text { train. }\end{array}$ & $\begin{array}{l}\text { Long } \\
\text { train. }\end{array}$ & Retrain. \\
\hline $\begin{array}{l}\text { Concentrated and rural districts in } \\
\text { agalomerations }\end{array}$ & 20 & 22 & 20 & 21 & 14 & 10 & 22 & 13 \\
\hline Urbanised areas & 36 & 40 & 36 & 37 & 34 & 41 & 44 & 31 \\
\hline Berlin, Postdam & 11 & 8 & 8 & 9 & 13 & 0 & 6 & 6 \\
\hline Saxony, Thuringia & 41 & 45 & 48 & 41 & 35 & 66 & 42 & 38 \\
\hline $\begin{array}{l}\text { Mecklenburg-Western-Pomerania, } \\
\text { Brandenburg }\end{array}$ & 12 & 13 & 16 & 18 & 5 & 21 & 3 & 19 \\
\hline Saxony-Anhalt & 14 & 11 & 13 & 13 & 19 & 3 & 31 & $\ddot{6}$ \\
\hline UE rate $\leq 15 \%$ & 35 & 34 & 37 & 34 & 34 & 24 & 42 & 38 \\
\hline $15 \%<$ UE rate $\leq 20 \%$ & 57 & 57 & 57 & 57 & 62 & 62 & 44 & 44 \\
\hline UE rate $>20 \%$ & 7 & 9 & 6 & 10 & 5 & 14 & 14 & 19 \\
\hline & \multicolumn{8}{|c|}{ Firms size of the last employer } \\
\hline No information & 15 & 13 & 13 & 8 & 32 & 28 & 19 & 0 \\
\hline 1 to 9 employees & 15 & 13 & 14 & 13 & 13 & 3 & 17 & 25 \\
\hline 10 to 99 employees & 31 & 29 & 28 & 34 & 25 & 17 & 36 & 25 \\
\hline 100 to 499 employees & 22 & 25 & 23 & 24 & 16 & 24 & 19 & 31 \\
\hline 500 employees or more & 17 & 21 & 22 & 20 & 14 & 28 & 8 & 19 \\
\hline \multicolumn{9}{|c|}{ Date of entry in and exit from the sample } \\
\hline Date of entry in the data* & Jan 91 & Jun 91 & Jun 91 & Apr 91 & Aug 90 & Sep 91 & Mar 91 & Sep 90 \\
\hline Date of entry in the sample* & Nov 93 & Aug 93 & Sep 93 & Aug 93 & Sep 93 & Jun 93 & Jul 93 & Jun 93 \\
\hline Date of beginning of prog.* & Jun 94 & May 94 & May 94 & Apr 94 & Aug 94 & Sep 94 & Jul 94 & Jul 94 \\
\hline
\end{tabular}

Note: $\quad{ }^{*}$ The results for variables marked with an asterisk are means rather than proportions. 
Table IB.1d: Loss of observations due to common support requirement in subsample analysis

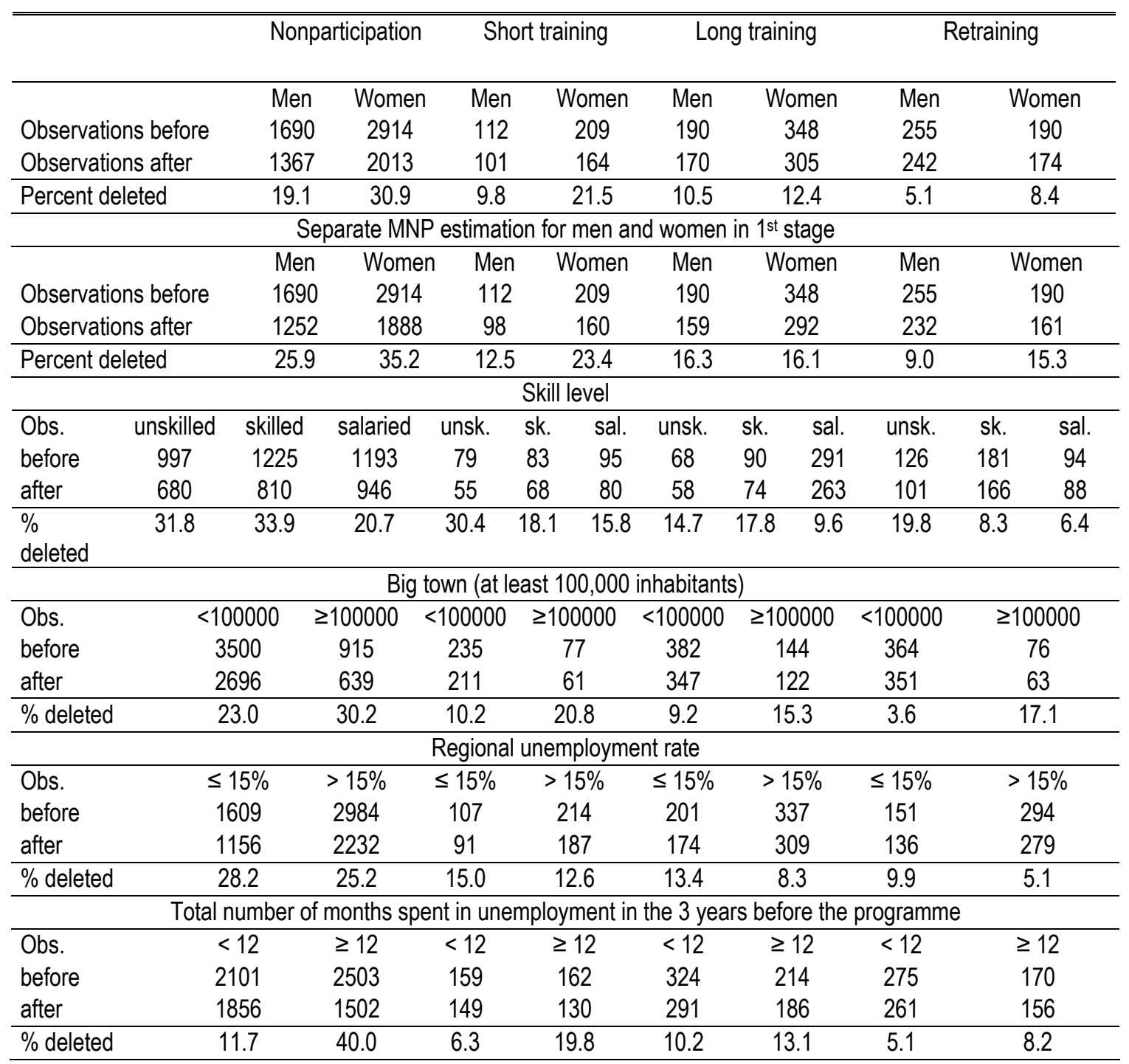

\section{Appendix IB.2: Match quality}

Table IB.2a: Concentration of the weights due to matching with replacement

\begin{tabular}{ccccc}
\hline \hline & & \multicolumn{2}{c}{ Treated } & \\
Control & Nonparticipation & Short training & Long training & Retraining \\
\hline Nonparticipation & & 58.45 & 59.52 & 59.14 \\
Short training & 41.95 & & 34.87 & 35.02 \\
Long training & 46.39 & 36.11 & & 43.69 \\
Retraining & 51.66 & 40.42 & 45.86 & \\
\hline
\end{tabular}

Note: $\quad$ Share of the largest $10 \%$ of the weights of the respective comparison group relative to the total sum of weights in that comparison group (concentration ratio) in $\%$. 
Figure IB.2: Effects prior to the programme $\left(\theta_{0}^{m, l}\right)$ : difference in \%-points
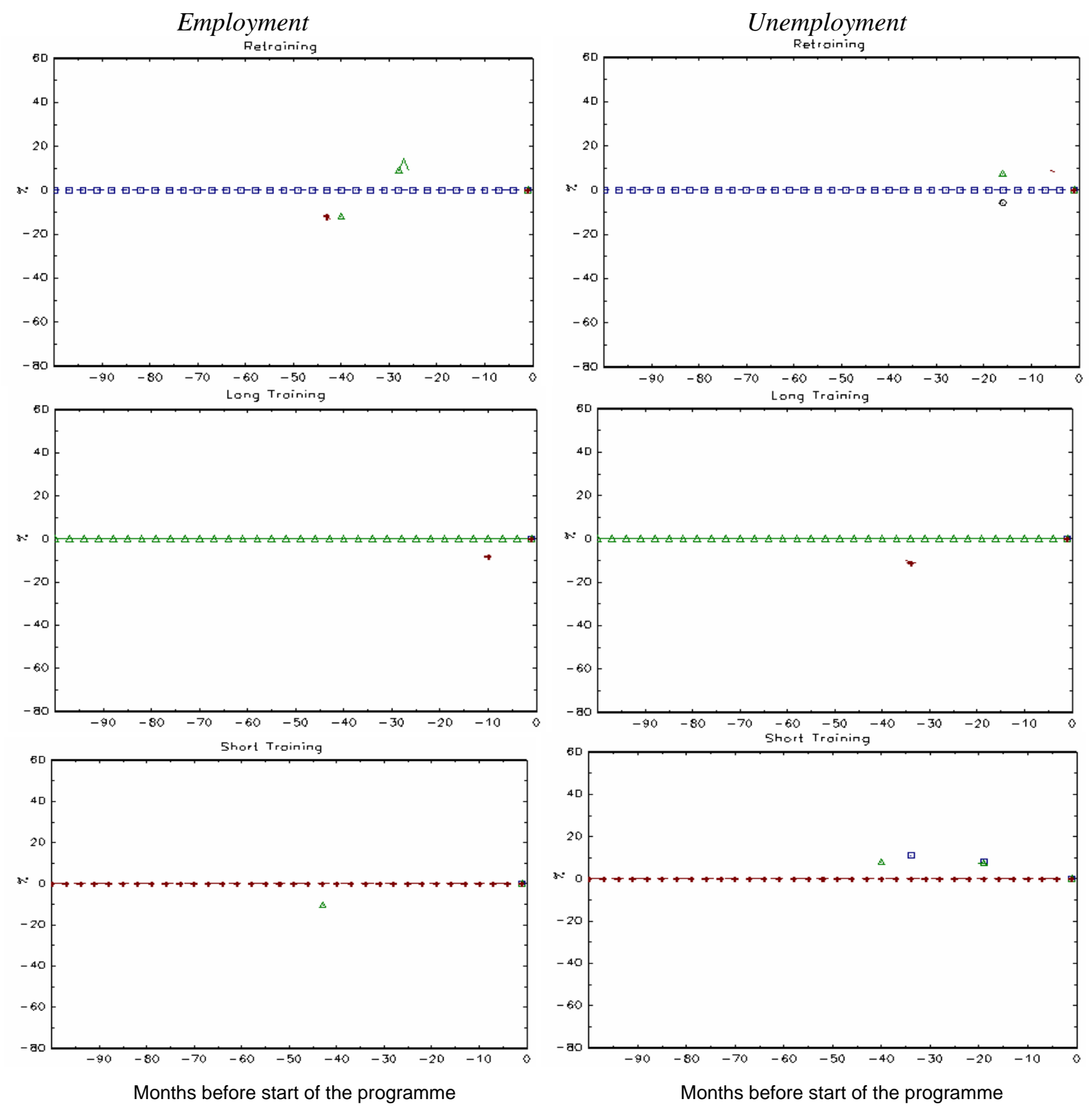

* - Non-participation $\quad$-- Retraining

A Long Training + - Short Training

Note: Figure shows significant (poit wise at the $5 \%$ level) differences of outcome variable prior to the programme (after matching). 
Table IB.2b: Differences in means of the matching variables and selected additional variables which are included in the propensity scores

\begin{tabular}{|c|c|c|c|c|}
\hline \multirow[b]{2}{*}{ Treated } & \multicolumn{4}{|c|}{ Control } \\
\hline & Nonparticipation & Short training & Long training & Retraining \\
\hline & \multicolumn{4}{|c|}{ Date of beginning of programme ${ }^{a}$} \\
\hline Short training & -0.636 & & 0.222 & 0.434 \\
\hline Long training & -0.814 & -1.071 & & -0.504 \\
\hline \multirow[t]{2}{*}{ Retraining } & -0.928 & -0.156 & -0.438 & \\
\hline & \multicolumn{4}{|c|}{ Womana $^{\mathrm{a}}$} \\
\hline Short training & 0.002 & & -0.007 & 0.006 \\
\hline Long training & -0.041 & -0.065 & & -0.004 \\
\hline \multirow[t]{2}{*}{ Retraining } & -0.013 & 0 & -0.018 & \\
\hline & \multicolumn{4}{|c|}{ Employed 12 months before programme ${ }^{a}$} \\
\hline Short training & -0.029 & & 0.014 & 0.022 \\
\hline Long training & -0.04 & 0.024 & & -0.001 \\
\hline \multirow[t]{2}{*}{ Retraining } & -0.087 & -0.029 & -0.013 & \\
\hline & \multicolumn{4}{|c|}{ Employed 24 months before programme } \\
\hline Short training & -0.058 & & 0.007 & 0 \\
\hline Long training & -0.034 & -0.011 & & -0.021 \\
\hline \multirow[t]{2}{*}{ Retraining } & -0.035 & 0.006 & -0.017 & \\
\hline & \multicolumn{4}{|c|}{ Employed 36 months before programme ${ }^{a}$} \\
\hline Short training & 0.038 & & 0 & 0.021 \\
\hline Long training & 0.039 & 0.012 & & 0.004 \\
\hline \multirow[t]{2}{*}{ Retraining } & 0.029 & 0.007 & 0.019 & \\
\hline & \multicolumn{4}{|c|}{ Time between start last UE spell before prog. and prog. start } \\
\hline Short training & -0.12 & & 0.008 & -0.079 \\
\hline Long training & -0.026 & -0.225 & & -0.268 \\
\hline \multirow{2}{*}{ Retraining } & 0.089 & 0.405 & -0.285 & \\
\hline & \multicolumn{4}{|c|}{ Duration of the last UE benefit spell before programme } \\
\hline Short training & $-1.053^{*}$ & & 0.291 & -0.032 \\
\hline Long training & -0.666 & -0.276 & & -0.021 \\
\hline \multirow[t]{2}{*}{ Retraining } & -0.78 & 0.159 & -0.109 & \\
\hline & \multicolumn{4}{|c|}{ Duration of the first UE spell 1993-1994 } \\
\hline Short training & $1.354^{*}$ & & -0.072 & -0.054 \\
\hline Long training & $1.1^{*}$ & -0.465 & & -0.326 \\
\hline \multirow[t]{2}{*}{ Retraining } & 0.692 & 0.364 & -0.133 & \\
\hline & \multicolumn{4}{|c|}{ Remaining UB claim at the end of last UE spell before prog. } \\
\hline Short training & 0.03 & & 0.138 & 0.376 \\
\hline Long training & 0.145 & -0.028 & & -0.13 \\
\hline \multirow[t]{2}{*}{ Retraining } & 0.077 & -0.649 & 0.231 & \\
\hline & \multicolumn{4}{|c|}{ Legal UB claim at the beginning of last UE spell before prog. } \\
\hline Short training & $-2.788^{*}$ & & 0.558 & 0.061 \\
\hline Long training & $-1.904^{*}$ & -0.298 & & -0.103 \\
\hline \multirow[t]{2}{*}{ Retraining } & $-1.841^{*}$ & -1.198 & 0.44 & \\
\hline & \multicolumn{4}{|c|}{ Propensity score control } \\
\hline Short training & -0.025 & & -0.01 & -0.007 \\
\hline Long training & -0.025 & -0.005 & & -0.017 \\
\hline Retraining & -0.035 & -0.005 & -0.022 & \\
\hline
\end{tabular}

Table IB. $2 \mathrm{~b}$ to be continued 
Table IB.2b: Differences in means of the matching variables and selected additional variables which are included in the propensity scores (continued)

\begin{tabular}{ccccc}
\hline \hline Treated & Nonparticipation & $\begin{array}{c}\text { Control } \\
\text { Short training }\end{array}$ & Long training & Retraining \\
\hline Short training & 0.008 & Propensity score treated & \\
Long training & 0.013 & 0.015 & 0.006 & 0.008 \\
Retraining & 0.018 & 0.013 & 0.014 & 0.013 \\
\hline
\end{tabular}

Note: $\quad$ Bold numbers indicate significance at the $5 \%$ level, numbers in italics relate to the $10 \%$ level and ${ }^{*}$ to the $1 \%$ level. a Variables used for calculating the distance metric in the matching procedure. 


\section{Appendix IC: Detailed estimation results from the multinomial probit model}

Table IC.1 shows the estimation results of a multinomial probit model (MNP) using simulated maximum likelihood with the GHK simulator. ${ }^{1}$ Although being fully parametric, the MNP is a flexible version of a discrete choice model, because it does not require the Independence of Irrelevant Alternatives assumption to hold. With respect to the specification of the covariance structure of choice specific error terms, we impose the normalisation that all correlations with nonparticipation are zero. Furthermore, the correlation between short training and retraining is set to zero for reasons of numerical stability (this should not be very restrictive since those types of programme cannot not be considered as close substitutes). Furthermore, to increase the numerical stability of the results we exclude some regional variables and some interaction terms from the choice indices related to long training and retraining (these variables are insignificant in a binary probit of this group against nonparticipation). As shown in Table B.2, it turns out that covariance terms are however not significant. The number of draws per equation and observation is another choice parameter. We choose 1000 draws, which is very large by usual standards.

Table IC.1: Estimated coefficients of a multinomial probit model for participation in a programme

\begin{tabular}{|c|c|c|c|c|c|c|}
\hline & & Short Training & \multicolumn{2}{|c|}{ Long Training } & \multicolumn{2}{|c|}{ Retraining } \\
\hline & Coeff. & Std. & Coeff. & Std. & Coeff. & Std. \\
\hline Constant & -4.40 & 2.78 & -3.32 & 1.81 & -1.71 & 1.68 \\
\hline Women & 0.01 & 0.17 & -0.13 & 0.11 & $-0.46^{*}$ & 0.11 \\
\hline Age/10 & -0.26 & 0.85 & 1.19 & 0.61 & 0.92 & 0.59 \\
\hline$($ Age/10)^2 & 0.01 & 0.11 & -0.17 & -2.08 & $-0.22^{*}$ & 0.08 \\
\hline Marital status: Single & 0.03 & 0.15 & -0.08 & 0.10 & -0.15 & 0.11 \\
\hline Children: No child & -0.08 & 0.16 & -0.04 & 0.10 & -0.01 & 0.11 \\
\hline \multicolumn{7}{|c|}{ Education (reference category: polytechnical degree, University degree) } \\
\hline No professional degree & -0.12 & 0.36 & $-1.16^{*}$ & 0.21 & -0.23 & 0.26 \\
\hline Professional degree & 0.39 & 0.34 & $-0.58^{*}$ & 0.14 & -0.24 & 0.21 \\
\hline \multicolumn{7}{|c|}{ Position in last job (reference category: master craftsman, skilled and unskilled worker) } \\
\hline Salaried employee & -0.28 & 0.23 & $0.53^{*}$ & 0.12 & -0.12 & 0.14 \\
\hline Part-time worker & 0.11 & 0.22 & 0.26 & 0.16 & -0.24 & 0.17 \\
\hline
\end{tabular}

Table B.1 to be continued

1 See for example Börsch-Supan, Hajivassiliou (1993) and Geweke, Keane and Runkle (1994). 
Table IC.1: Estimated coefficients of a multinomial probit model for participation (continued-1)

\begin{tabular}{|c|c|c|c|c|c|c|}
\hline & \multicolumn{2}{|c|}{ Short Training } & \multicolumn{2}{|c|}{ Long Training } & \multicolumn{2}{|c|}{ Retraining } \\
\hline & Coeff. & Std. & Coeff. & Std. & Coeff. & Std. \\
\hline \multicolumn{7}{|c|}{$\begin{array}{l}\text { Last occupation (reference category: Chemical worker, polymer processing, metal production and processing, textile, leather } \\
\text { clothing, paper manufacture and processing, printing, mining, stone, ceramics and glass making and/or processing) }\end{array}$} \\
\hline $\begin{array}{l}\text { Plumbing, metal construction technology, technology, natural } \\
\text { sciences, machinist, electronics }\end{array}$ & 0.10 & 0.28 & $0.57^{*}$ & 0.22 & -0.30 & 0.19 \\
\hline $\begin{array}{l}\text { Food and nutrition, merchant (goods and services), transportation, } \\
\text { storage, health services, hairdressing, guest assistance, house- } \\
\text { keeping, cleaning, security services, social services, education, } \\
\text { counselling, media, humanities, arts, unskilled worker }\end{array}$ & -0.11 & 0.25 & 0.17 & 0.19 & $-0.48^{*}$ & 0.15 \\
\hline Construction, woodworking & 0.04 & 0.33 & 0.18 & 0.27 & -0.39 & 0.21 \\
\hline Agriculture, forestry, fishing & 0.02 & 0.37 & 0.31 & 0.28 & -0.27 & 0.21 \\
\hline Administration, office work, business and social sciences & 0.24 & 0.31 & $0.71^{*}$ & 0.22 & -0.28 & 0.22 \\
\hline \multicolumn{7}{|c|}{ Industrial sector (reference category: Energy and supply industry, mining, manufacturing (without construction)) } \\
\hline $\begin{array}{l}\text { Commerce, banking, insurance, local and regional authorities, } \\
\text { social insurance, non-profit organisations, private household, } \\
\text { transportation, telecommunications, other services }\end{array}$ & 0.19 & 0.17 & -0.12 & 0.10 & 0.08 & 0.11 \\
\hline Agriculture, forestry, fishing & -0.43 & 0.62 & -0.38 & 0.36 & -0.05 & 0.29 \\
\hline Construction & -0.25 & 0.30 & -0.38 & 0.20 & -0.34 & 0.19 \\
\hline \multicolumn{7}{|c|}{ Last monthly earnings } \\
\hline allact & 0.48 & 0.33 & 0.33 & 0.32 & 0.35 & 0.29 \\
\hline No inforr & 1.07 & 1.08 & 0.96 & 1.12 & 0.78 & 0.99 \\
\hline $2500>$ & -0.09 & 0.16 & -0.21 & 0.11 & -0.20 & 0.11 \\
\hline \multicolumn{7}{|c|}{ Remaining unemployment (UE) benefits claim at the end of the last unemployment spell before entry in the programme } \\
\hline Remaining UE benefits claim (in months) & 0.20 & 0.09 & 0.06 & 0.04 & 0.11 & 0.05 \\
\hline No information & $2.71^{*}$ & 0.67 & $2.00^{*}$ & 0.21 & $1.91^{*}$ & 0.18 \\
\hline & 0.23 & 0.34 & -0 . & 0.22 & -0.07 & 0.22 \\
\hline and $>0$ & $2.06^{*}$ & 0.69 & $1.85^{*}$ & 0.35 & $1.41^{*}$ & 0.36 \\
\hline \multicolumn{7}{|c|}{ Legal UE benefits claim at the beginning of the last unemployment spell before the programme } \\
\hline Legally claim* (in months) & -0.08 & 0.06 & -0.04 & 0.04 & -0.06 & 0.04 \\
\hline Alnim & -0.91 & 0.36 & 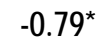 & 0.21 & $-0.74^{*}$ & 0.22 \\
\hline & -0.23 & 0.29 & 0.1 & 0.17 & -0.18 & 0.17 \\
\hline & -0.52 & 0.52 & -0.72 & 0.30 & 0.04 & 0.32 \\
\hline \multicolumn{7}{|c|}{ Various historical un/ out-of/employment information before the "first unemployment period" } \\
\hline Month & -1.09 & 1.51 & -1.00 & 1.11 & -1.87 & 1.01 \\
\hline Month & 0.22 & 0.98 & 0. & 0.68 & 0.97 & 0.62 \\
\hline ths (in \%) before the UE spella & 0.04 & 0.04 & $0.09 *$ & 0.03 & $0.09 *$ & 0.03 \\
\hline Prop & 0.09 & 0.06 & & 0.04 & $0.11^{*}$ & 0.04 \\
\hline efore UEPa & -3.39 & 3.72 & -5 & 2.49 & -2.28 & 2.48 \\
\hline pells up to 2 years before UEPa ${ }^{\wedge} 2$ & 20.63 & 16.47 & $30.15^{*}$ & 11.01 & 14.89 & 10.83 \\
\hline Duration of last UE spell before programme & -0.51 & 0.85 & -0.71 & 0.64 & -1.24 & 0.71 \\
\hline ramme $^{a} \wedge 2$ & -0.73 & 0.42 & & 0.33 & -0.75 & 0.39 \\
\hline Duratic & $-1.61^{*}$ & 0.38 & -1 & 0.25 & $-1.76^{*}$ & 0.23 \\
\hline $\begin{array}{l}\text { Time since beginning of last UE spell (before the prog.) even if } \\
\text { other state between UE and prog. }{ }^{\text {a }}\end{array}$ & $5.30^{*}$ & 0.98 & $3.59 *$ & 0.52 & $4.30^{*}$ & 0.48 \\
\hline $\begin{array}{l}\text { Log(time since beginning of last UE spell (before the prog.) even if } \\
\text { other state between UE and prog. a) }\end{array}$ & -1.31 & 0.77 & 0.07 & 0.52 & -0.16 & 0.52 \\
\hline 12 months $\geq$ time between prog. and last job & 0.61 & 0.28 & 0.4 & 0.15 & 0.35 & 0.16 \\
\hline pl. $\rightarrow$ UE & 0.55 & 0.31 & & 0.16 & -0.12 & 0.16 \\
\hline Number of prog. in year before actual programme & 0.11 & 0.35 & -0.47 & 0.26 & 0.05 & 0.22 \\
\hline \multicolumn{7}{|c|}{ Unemployed and employment status before programme (reference categories: out-of-labour, missing) } \\
\hline Unemployed the $6^{\text {th }}$. month before prog. & -0.44 & 0.37 & -0.35 & 0.21 & -0.14 & 0.22 \\
\hline Unemployed the $24^{\text {th }}$. month before prog. & -0.30 & 0.25 & -0.37 & 0.18 & $-0.63^{*}$ & 0.18 \\
\hline fore prog. & -0.74 & 0.33 & -0.13 & 0.19 & -0.49 & 0.22 \\
\hline Employed the $6^{\text {th. }}$. month before prog. & -0.33 & 0.35 & -0.53 & 0.22 & -0.16 & 0.24 \\
\hline Employed the $24^{\text {th }}$. $r$ & -0.08 & 0.19 & -0.13 & 0.13 & -0.09 & 0.12 \\
\hline Employed the $36^{\text {th }}$. month before prog. & -0.27 & 0.17 & -0.02 & 0.10 & -0.16 & 0.11 \\
\hline
\end{tabular}

Table B.1 to be continued 
Table IC.1: Estimated coefficients of a multinomial probit model for participation (continued-2)

\begin{tabular}{|c|c|c|c|c|c|c|}
\hline & \multicolumn{2}{|c|}{ Short Training } & \multicolumn{2}{|c|}{ Long Training } & \multicolumn{2}{|c|}{ Retraining } \\
\hline & Coeff. & Std. & Coeff. & Std. & Coeff. & Std. \\
\hline \multicolumn{7}{|c|}{ Regional information } \\
\hline Big City & 0.24 & 0.32 & -0.27 & 0.18 & -0.31 & 0.20 \\
\hline Net migration per 1000 inhabitants. a (if local district not missing) & 0.12 & 0.06 & 0.02 & 0.03 & 0.04 & 0.04 \\
\hline Inhabitants below age 15 in $\%$ of the $15-65$ year olds. a,b & 11.94 & 5.36 & & & $7.02^{*}$ & 2.60 \\
\hline Inhabitants above age 65 in $\%$ of the $15-65$ year olds. a,b & 11.84 & 5.22 & & & 6.21 & 2.49 \\
\hline Inhabitants of age $15-65$ in $\%$ of all inhabitants.a,b & 25.30 & 11.17 & -0.11 & 0.16 & $13.92^{*}$ & 5.40 \\
\hline Inhabitants above age 75 in \% of all inhabitants.a,b & 0.77 & 2.66 & 0.32 & 0.53 & 3.16 & 1.79 \\
\hline Recipients of social assistance per 1000 inhabitants.a,b & 0.03 & 0.12 & -0.06 & 0.08 & -0.09 & 0.08 \\
\hline $\begin{array}{l}\text { Fraction of non-German nationals among recipients of social } \\
\text { assistance. } a, b\end{array}$ & -0.01 & 0.16 & -0.10 & 0.11 & 0.06 & 0.10 \\
\hline Gross value added - fraction agriculture and forestry.a,b & -23.13 & 10.13 & & & $-13.6^{*}$ & 4.87 \\
\hline Gross value added - $f$ & -22.96 & 10.13 & & & $-12.78^{*}$ & 4.89 \\
\hline Gross & -22.95 & 10.11 & & & $-12.74^{*}$ & 4.88 \\
\hline transportations $\mathrm{a}, \mathrm{b}$ & -23.01 & 10.13 & & & $-12.59^{*}$ & 4.88 \\
\hline Log(Gross V & 0.42 & 1.21 & 0.73 & 0.73 & -0.01 & 0.83 \\
\hline $\log (T$ & -0.28 & 0.44 & 0.16 & 0.24 & -0.27 & 0.28 \\
\hline Net $m$ & 0.01 & 0.01 & 0.00 & 0.00 & -0.00 & 0.01 \\
\hline Rural area & -0.43 & 0.23 & -0.11 & 0.12 & & \\
\hline \multicolumn{7}{|c|}{ (reference category: Saxony-Anhalt) } \\
\hline No regic & 0.15 & 0.70 & -0.42 & 0.49 & 0.44 & 0.48 \\
\hline Berlin, $\mathrm{Pc}$ & -0.52 & 0.76 & -0.48 & 0.51 & 0.79 & 0.50 \\
\hline Saxony, Thuringia & 0.23 & 0.71 & -0.24 & 0.49 & 0.47 & 0.48 \\
\hline Mecklenburg-Western-Pomerania, Brandenburg & 0.66 & 0.73 & 0.26 & 0.51 & 1.13 & 0.51 \\
\hline \multicolumn{7}{|c|}{ (reference category: UE rate $>20 \%$ ) } \\
\hline UE rate $\leq 15 \%$ & -0.51 & 0.28 & -0.07 & 0.18 & -0.37 & 0.19 \\
\hline $15 \%<$ UE rate $\leq 20 \%$ (E) & -0.51 & 0.25 & -0.22 & 0.18 & $-0.51^{*}$ & 0.17 \\
\hline \multicolumn{7}{|c|}{ Firms size of the last employer (reference category: 100 employees or more) } \\
\hline No information & 0.18 & 0.31 & 0.24 & 0.18 & -0.22 & 0.22 \\
\hline 1 to 9 employees & -0.24 & 0.19 & -0.03 & 0.13 & -0.16 & 0.13 \\
\hline 10 to 99 employees & -0.26 & 0.15 & -0.09 & 0.10 & -0.16 & 0.10 \\
\hline Date of entry in the sa & $-0.49^{*}$ & 0.17 & $-0.52^{-}$ & 0.11 & $-0.61^{*}$ & 0.10 \\
\hline $\begin{array}{l}\text { Age }<26 * \text { time since beginning of last UE spell (before the prog. } \\
\text { even if other state between UE and prog.) a }\end{array}$ & -0.21 & 0.32 & 0.27 & 0.23 & -0.04 & 0.21 \\
\hline Age $\geq 50^{*}$ months of last employment spells & -0.75 & 1.74 & -1.94 & 1.23 & & \\
\hline Empl. $\rightarrow$ UE in 6 months before prog * claima & -0.10 & 0.06 & & & & \\
\hline Polytechnical degree *time since beginning of last UE spell (before & -0.61 & 0.65 & -0.36 & 0.32 & -0.43 & 0.52 \\
\hline
\end{tabular}

Note: $\quad$ Simulated maximum likelihood estimates using the GHK simulator (1000 draws in simulator for each observation and choice equation). Coefficients of the category NONPARTICIPATION are normalised to zero. Inference is based on the outer product of the gradient estimate of the covariance matrix of the coefficients ignoring simulation error. $N=5908$. Value of the log-likelihood function: -0.570502 . Bold numbers indicate significance at the $5 \%$ level, numbers in italics relate to the $10 \%$ level and * to the $1 \%$ level. a The variable is scaled. ${ }^{b}$ If local district not missing. 
Table IC.2: Estimated covariance and correlation matrices of the error terms in the multinomial

probit

\begin{tabular}{lllllllll||}
\hline \hline & \multicolumn{2}{l}{ Nonparticipation } & \multicolumn{2}{l|}{ Short Training } & \multicolumn{2}{l||}{ Long Training } & \multicolumn{2}{l|}{ Retraining } \\
\hline & Coef & t-val & Coef & t-val & Coef & t-val & Coef & t-val \\
\hline NONP & 1 & - & 0 & - & 0 & - & 0 & - \\
ST & 0 & 1 & - & 0.25 & 0.53 & 0 & - \\
LT & 0 & & 0.24 & & 1.06 & 4.59 & -1.00 & -1.22 \\
RT & 0 & & 0 & & -0.69 & & 2.01 & 1.21 \\
\hline
\end{tabular}

Note: $\quad$ Diagonal and upper triangular matrix shows covariance terms. Correlations are shown in the part below the main diagonal. In the estimation Cholesky factors are used for parameterisation to ensure that the estimated covariance matrix of the error terms is positive definite. 


\section{Appendix ID: Additional estimation results}

\section{Appendix ID.1: Effects without significance levels}

Figure ID.1a: Dynamics of the effects (ATET) without significance levels

Employment
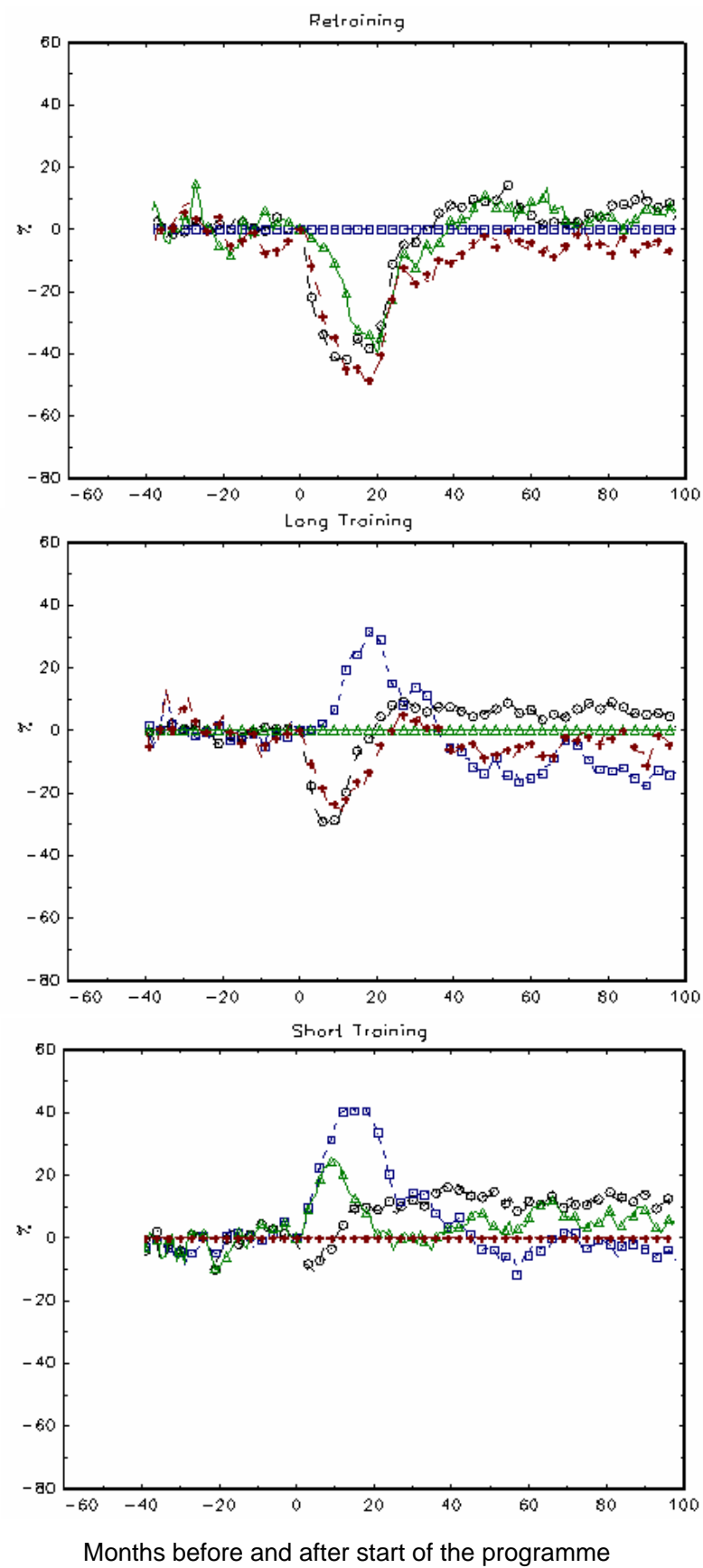

๑ - Non-participation $\boxminus--$ Retraining
Unemployment
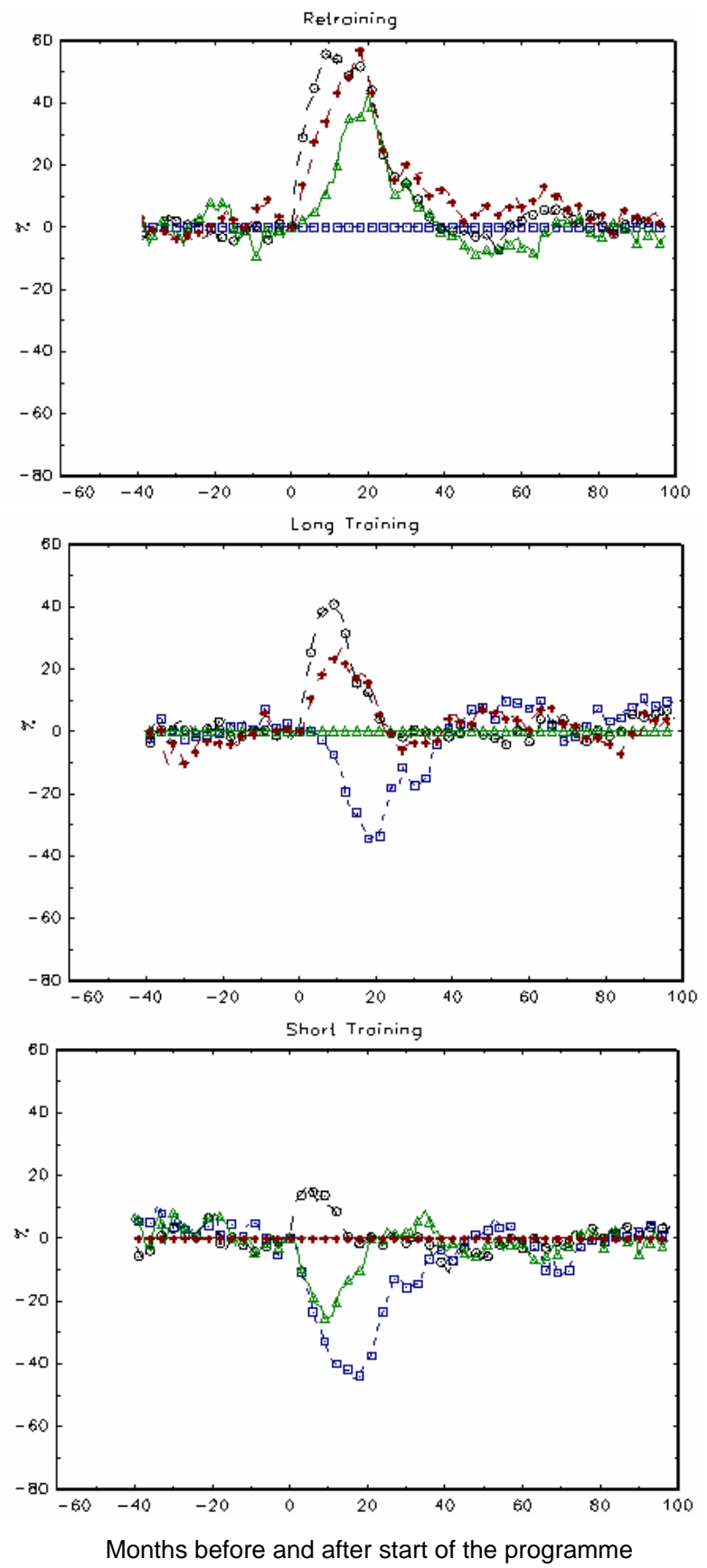

^ Long Training + - Short Training 
Figure ID.1b: Dynamics of the effects (ATET) without significance levels for men -

MNP estimation different for men and women

Employment
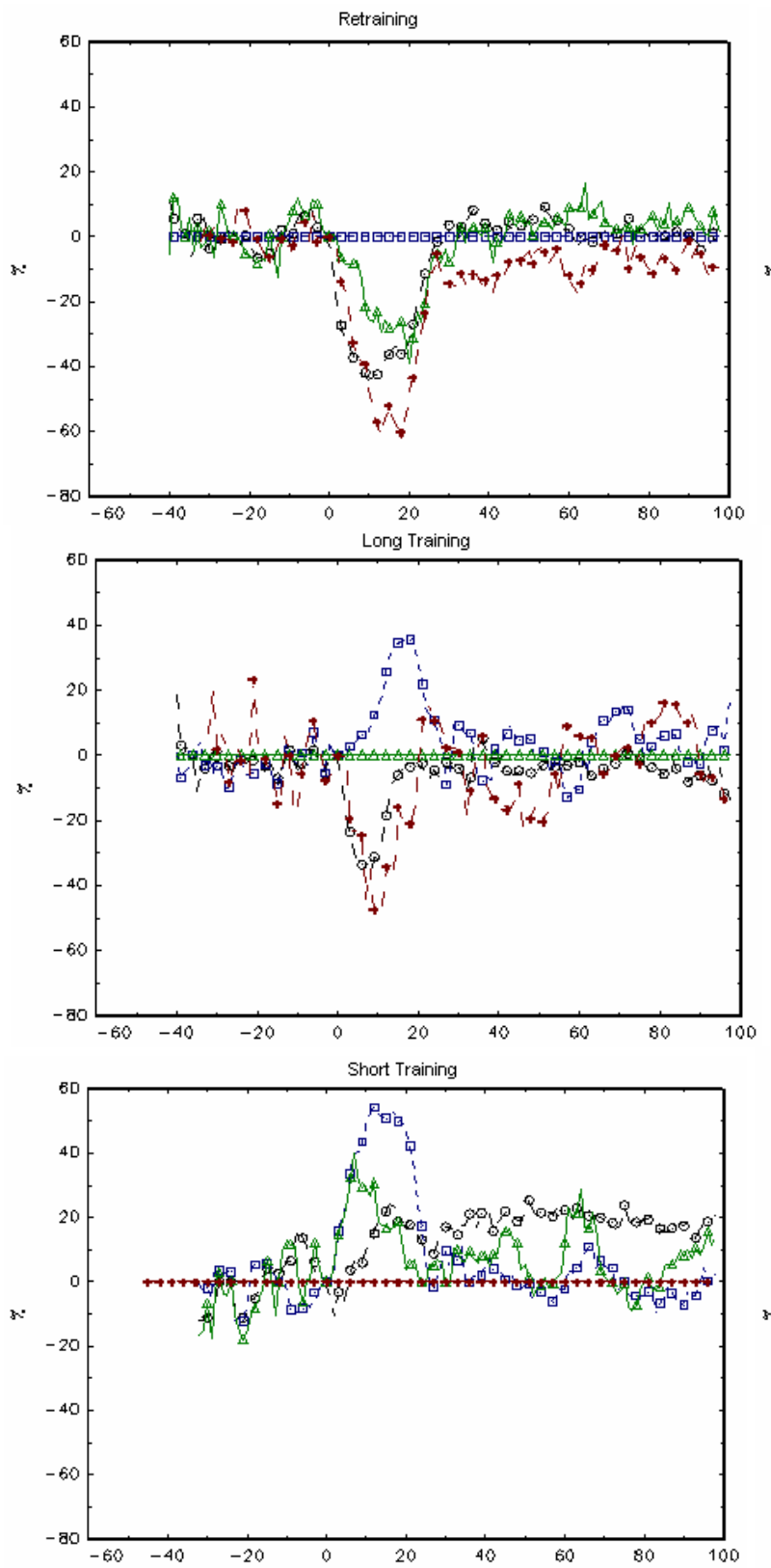

Months before and after start of the programme

* - Non-participation $\boxminus-$ - Retraining

\section{Unemployment}
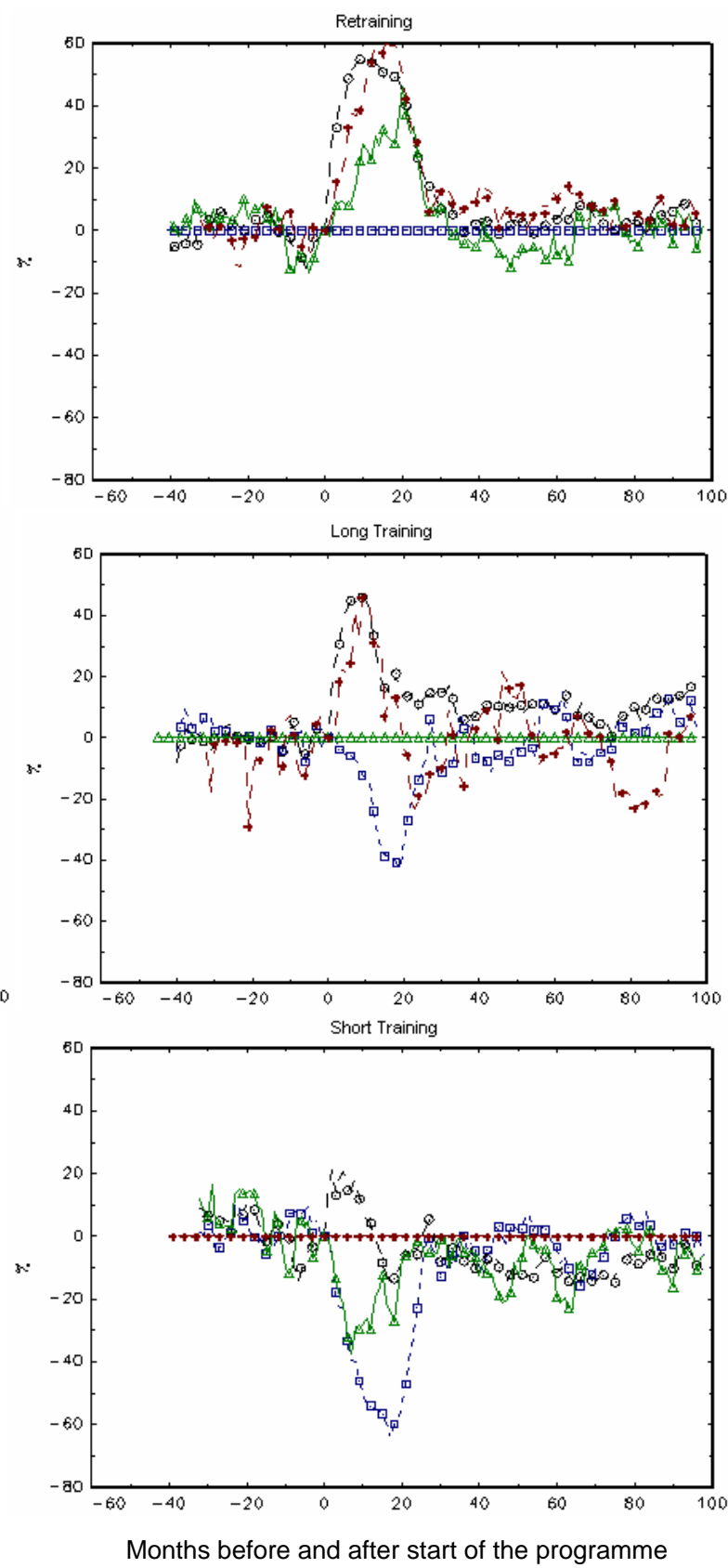

\& Long Training + - Short Training 
Figure ID.1c: Dynamics of the effects (ATET) without significance levels for women -

MNP estimation different for men and women

Employment
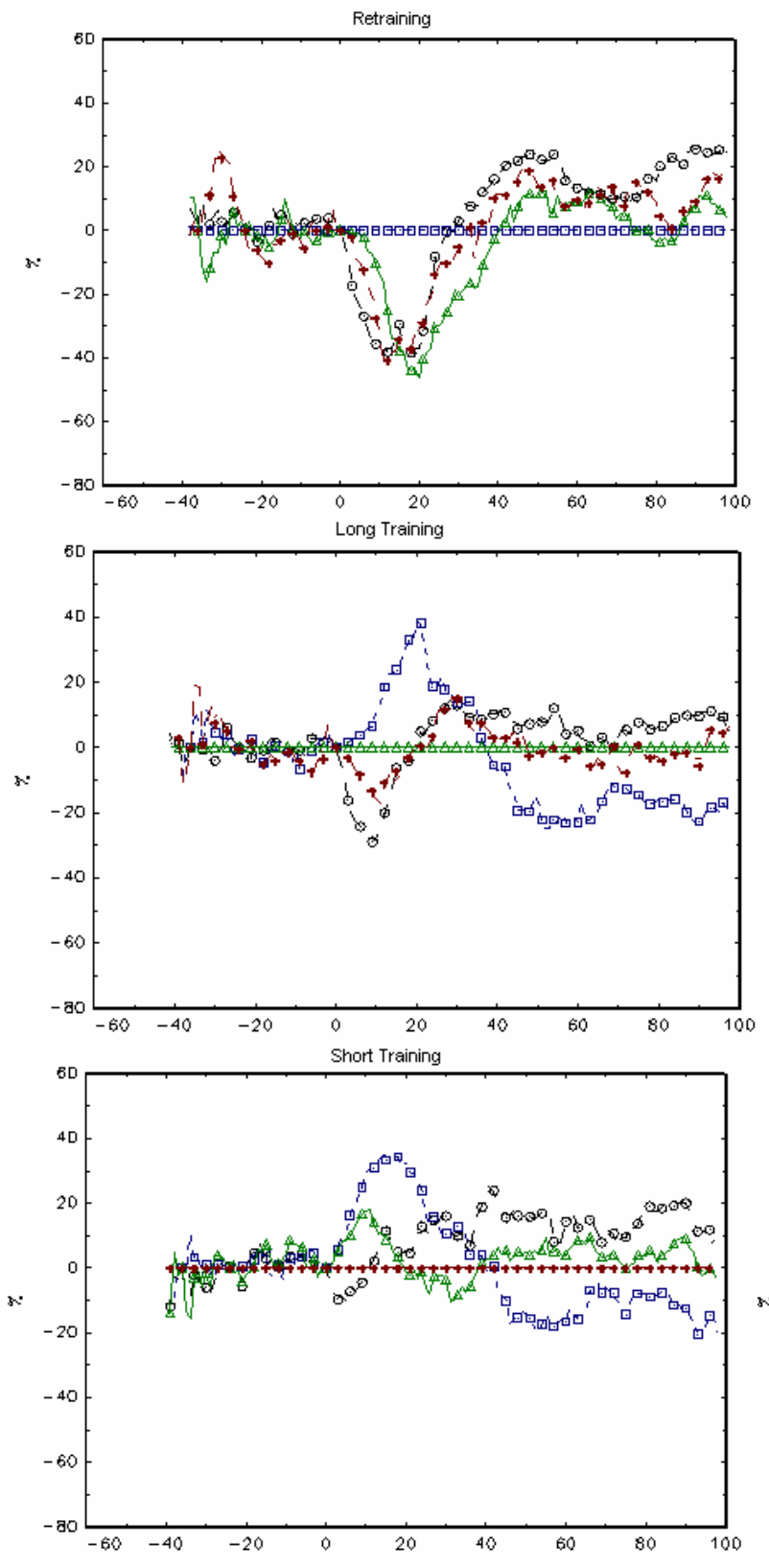

Months before and after start of the programme

* - Non-participation $\boxminus-$ - Retraining

\section{Unemployment}
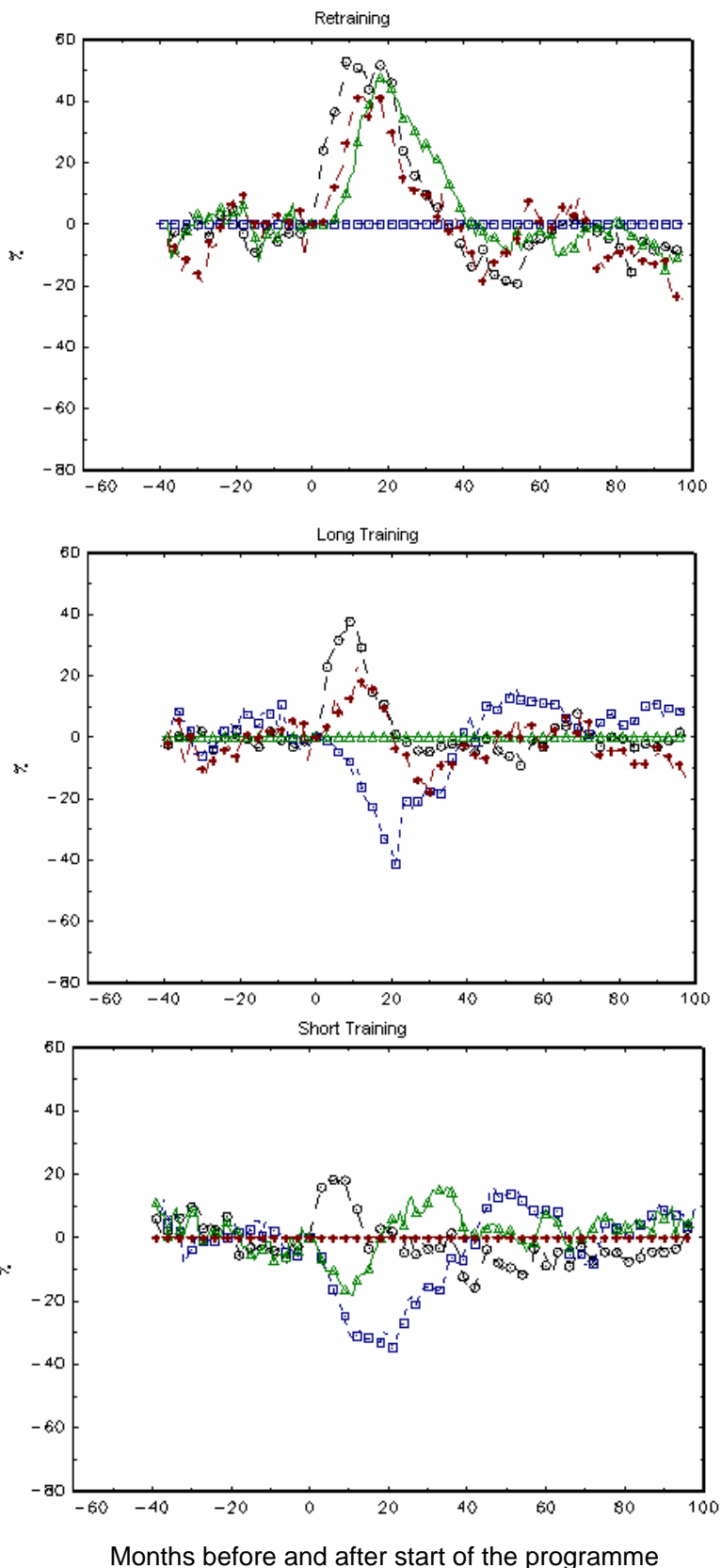

Months before and after start of the programme

- Long Training + - Short Training 


\section{Appendix ID.2: Additional outcome variables}

Table ID.2a: Estimated employment effects 8 years after programme start

\begin{tabular}{cccccccccccc}
\hline \hline \multirow{2}{*}{ State $\mathrm{m}$} & \multirow{2}{*}{ State I } & \multicolumn{2}{c}{ Sample size } & $E\left(Y^{m}\right.$ & \multicolumn{2}{c}{$E\left(Y^{m}\right.$} & $E\left(Y^{l}\right.$ & $E\left(Y^{l}\right.$ & & & \\
& & $\mathrm{m}$ & $\mid$ & $\mid S=m)$ & $\mid S=l)$ & $\mid S=m)$ & $\mid S=l)$ & $\theta_{0}^{m, l}$ & $-\theta_{0}^{l, m}$ & $\gamma_{0}^{m, l}$ \\
\hline (1) & $(2)$ & $(3)$ & $(4)$ & $(5)$ & $(6)$ & $(7)$ & $(8)$ & $(9)$ & $(10)$ & $(11)$ \\
Short training & nonparticip. & 292 & 3542 & 52.7 & 55.4 & 40.2 & 40.4 & $\mathbf{1 2 . 5 ^ { * }}$ & $\mathbf{1 5 . 0 ^ { * }}$ & $\mathbf{1 4 . 3 ^ { * }}$ \\
Short training & long training & 292 & 502 & 52.7 & 52.0 & 46.9 & 47.4 & 5.8 & 4.6 & 11.5 \\
Short training & retraining & 292 & 429 & 52.7 & 59.6 & 56.6 & 53.1 & -3.9 & 6.5 & -0.1 \\
Long training & nonparticip. & 502 & 3542 & 47.4 & 41.1 & 42.8 & 40.4 & 4.6 & 0.7 & 1.4 \\
Long training & retraining & 502 & 429 & 47.4 & 45.9 & 61.7 & 53.1 & $-\mathbf{- 1 4 . 3 ^ { * }}$ & $-\mathbf{7 . 2}$ & $\mathbf{- 1 1 . 5}$ \\
Retraining & nonparticip. & 429 & 3542 & 53.1 & 52.7 & 44.6 & 40.4 & $\mathbf{8 . 5}$ & $\mathbf{1 2 . 3 ^ { * }}$ & $\mathbf{1 2 . \mathbf { 8 } ^ { * }}$ \\
\hline
\end{tabular}

Note: Bold numbers indicate significance at the $5 \%$ level, numbers in italics relate to the $10 \%$ level and ${ }^{*}$ to the $1 \%$ level. Outcome variable: subsidised and unsubsidised employment.

Table ID.2b: Estimated 'Job creation schemes and structural adjustment measures ' (employment) effects 8 years after programme start

\begin{tabular}{|c|c|c|c|c|c|c|c|c|c|c|}
\hline \multirow{2}{*}{ State $m$} & \multirow{2}{*}{ State I } & \multicolumn{2}{|c|}{ Sample size } & \multirow{2}{*}{$\begin{array}{l}E\left(Y^{m}\right. \\
\mid S=m)\end{array}$} & \multirow{2}{*}{$\begin{array}{l}E\left(Y^{m}\right. \\
\mid S=l)\end{array}$} & \multirow{2}{*}{$\begin{array}{l}E\left(Y^{l}\right. \\
\mid S=m)\end{array}$} & \multirow{2}{*}{$\begin{array}{l}E\left(Y^{l}\right. \\
\mid S=l)\end{array}$} & \multirow[b]{2}{*}{$\theta_{0}^{m, l}$} & \multirow[b]{2}{*}{$-\theta_{0}^{l, m}$} & \multirow[b]{2}{*}{$\gamma_{0}^{m, l}$} \\
\hline & & $\mathrm{m}$ & 1 & & & & & & & \\
\hline (1) & (2) & (3) & (4) & (5) & (6) & (7) & (8) & (9) & (10) & (11) \\
\hline Short training & nonparticip. & 292 & 3542 & 3.8 & 2.3 & 4.2 & 4.2 & -0.4 & -1.9 & -1.2 \\
\hline Short training & long training & 292 & 502 & 3.8 & 5.1 & 1.5 & 3.4 & 2.3 & 1.7 & 1.0 \\
\hline Short training & retraining & 292 & 429 & 3.8 & 2.4 & 2.9 & 3.7 & 0.9 & -1.3 & -1.1 \\
\hline Long training & nonparticip. & 502 & 3542 & 3.4 & 1.9 & 4.0 & 4.2 & -0.6 & -2.3 & -2.1 \\
\hline Long training & retraining & 502 & 429 & 3.4 & 1.0 & 5.0 & 3.7 & -1.6 & -2.7 & -2.5 \\
\hline Retraining & nonparticip. & 429 & 3542 & 3.7 & 4.1 & 3.4 & 4.2 & 0.3 & -0.1 & 0.1 \\
\hline
\end{tabular}

Note: $\quad$ Bold numbers indicate significance at the $5 \%$ level, numbers in italics relate to the $10 \%$ level and * to the $1 \%$ level. Outcome variable: subsidised employment in job creation schemes or structural adjustment measures.

Table ID.2c: Estimated 'temporary wage subsidies' ( employment) effects 8 years after programme start

\begin{tabular}{|c|c|c|c|c|c|c|c|c|c|c|}
\hline \multirow{2}{*}{ State $\mathrm{m}$} & \multirow{2}{*}{ State I } & \multicolumn{2}{|c|}{ Sample size } & \multirow{2}{*}{$\begin{array}{l}E\left(Y^{m}\right. \\
\mid S=m)\end{array}$} & \multirow{2}{*}{$\begin{array}{l}E\left(Y^{m}\right. \\
\mid S=l)\end{array}$} & \multirow{2}{*}{$\begin{array}{l}E\left(Y^{l}\right. \\
\mid S=m)\end{array}$} & \multirow{2}{*}{$\begin{array}{l}E\left(Y^{l}\right. \\
\mid S=l)\end{array}$} & \multirow[b]{2}{*}{$\theta_{0}^{m, l}$} & \multirow[b]{2}{*}{$-\theta_{0}^{l, m}$} & \multirow[b]{2}{*}{$\gamma_{0}^{m, l}$} \\
\hline & & $\mathrm{m}$ & I & & & & & & & \\
\hline (1) & (2) & (3) & (4) & (5) & (6) & (7) & (8) & (9) & (10) & (11) \\
\hline Short training & nonparticip. & 292 & 3542 & 1.7 & 1.3 & 1.8 & 1.8 & -0.1 & -0.5 & -0.2 \\
\hline Short training & long training & 292 & 502 & 1.7 & 2.3 & 2.5 & 2.6 & -0.8 & -0.3 & -2.2 \\
\hline Short training & retraining & 292 & 429 & 1.7 & 1.4 & 1.3 & 1.9 & 0.4 & -0.5 & -0.5 \\
\hline Long training & nonparticip. & 502 & 3542 & 2.6 & 4.3 & 1.2 & 1.8 & 1.4 & 2.5 & 2.3 \\
\hline Long training & retraining & 502 & 429 & 2.6 & 3.5 & 0.6 & 1.9 & 2.0 & 1.6 & 2.3 \\
\hline Retraining & nonparticip. & 429 & 3542 & 1.9 & 2.0 & 0.9 & 1.8 & 1.0 & 0.2 & 0.2 \\
\hline
\end{tabular}

Note: $\quad$ Bold numbers indicate significance at the $5 \%$ level, numbers in italics relate to the $10 \%$ level and ${ }^{*}$ to the $1 \%$ level. Outcome variable: employment subsidised with temporary wage subsidies. 
Table ID.2d: Estimated employment with stable earnings effects 2 and 8 years after programme start

\begin{tabular}{|c|c|c|c|c|c|c|c|c|c|c|}
\hline \multirow{2}{*}{ Outcome } & \multirow{2}{*}{$\begin{array}{c}\text { Month after } \\
\text { beginning }\end{array}$} & \multicolumn{2}{|c|}{ Sample size } & \multirow{2}{*}{$\begin{array}{l}E\left(Y^{m}\right. \\
\mid S=m)\end{array}$} & \multirow{2}{*}{$\begin{array}{l}E\left(Y^{m}\right. \\
\mid S=l)\end{array}$} & \multirow{2}{*}{$\begin{array}{l}E\left(Y^{l}\right. \\
\mid S=m)\end{array}$} & \multirow{2}{*}{$\begin{array}{l}E\left(Y^{l}\right. \\
\mid S=l)\end{array}$} & \multirow[b]{2}{*}{$\theta_{0}^{m, l}$} & \multirow[b]{2}{*}{$-\theta_{0}^{l, m}$} & \multirow{2}{*}{$\gamma_{0}^{m, l}$} \\
\hline & & $\mathrm{m}$ & I & & & & & & & \\
\hline (1) & (2) & (3) & (4) & (5) & (6) & $(7)$ & (8) & (9) & $(10)$ & $(11)$ \\
\hline \multicolumn{11}{|c|}{ Short training (m) compared to nonparticipation (I) } \\
\hline \multirow[t]{2}{*}{ Employed } & 24 & 292 & 3541 & 39.0 & 57.6 & 28.0 & 27.4 & $11.0^{*}$ & $30.2^{\star}$ & $25.1^{*}$ \\
\hline & 96 & 292 & 3541 & 44.2 & 37.4 & 31.2 & 32.0 & $13.0^{*}$ & $15.4^{*}$ & $14.8^{*}$ \\
\hline \multicolumn{11}{|c|}{ Short training $(\mathrm{m})$ compared to long training $(\mathrm{I})$} \\
\hline \multirow[t]{2}{*}{ Employed } & 24 & 292 & 502 & 39.0 & 34.3 & 41.2 & 37.1 & -2.2 & -2.8 & 8.9 \\
\hline & 96 & 292 & 502 & 44.2 & 41.3 & 36.3 & 37.3 & 7.9 & 4.0 & 11.3 \\
\hline \multicolumn{11}{|c|}{ Short training $(\mathrm{m})$ compared to retraining $(\mathrm{I})$} \\
\hline \multirow[t]{2}{*}{ Employed } & 24 & 292 & 429 & 39.0 & 42.1 & 19.0 & 22.6 & $20.0^{*}$ & $19.5^{*}$ & $27.9^{*}$ \\
\hline & 96 & 292 & 429 & 44.2 & 49.8 & 46.2 & 44.5 & -2.0 & 5.3 & 1.3 \\
\hline \multicolumn{11}{|c|}{ Long training $(\mathrm{m})$ compared to nonparticipation (I) } \\
\hline \multirow[t]{2}{*}{ Employed } & 24 & 502 & 3541 & 37.1 & 42.1 & 28.0 & 27.4 & $9.1^{*}$ & $14.7^{*}$ & $12.9^{*}$ \\
\hline & 96 & 502 & 3541 & 37.3 & 32.9 & 32.5 & 32.0 & 4.8 & 0.9 & 1.6 \\
\hline \multicolumn{11}{|c|}{ Long training $(\mathrm{m})$ compared to retraining $(\mathrm{I})$} \\
\hline \multirow[t]{2}{*}{ Employed } & 24 & 502 & 429 & 37.1 & 41.0 & 23.7 & 22.6 & $13.4^{*}$ & $18.4^{*}$ & $15.9^{*}$ \\
\hline & 96 & 502 & 429 & 37.3 & 37.0 & 53.4 & 44.5 & $-16.1^{*}$ & -7.5 & -10.9 \\
\hline \multicolumn{11}{|c|}{ Retraining (m) compared to nonparticipation (I) } \\
\hline \multirow[t]{2}{*}{ Employed } & 24 & 429 & 3541 & 22.6 & 25.0 & 33.0 & 27.4 & $-10.4^{*}$ & -2.4 & -4.2 \\
\hline & 96 & 429 & 3541 & 44.5 & 43.6 & 35.7 & 32.0 & 8.8 & 11.6 & $12.5^{*}$ \\
\hline
\end{tabular}

Note: $\quad$ Bold numbers indicate significance at the $5 \%$ level, numbers in italics relate to the $10 \%$ level and * to the $1 \%$ level. The outcome variable "employment with stable earnings" is a dummy that equals 1 if earnings in the respective month are at least $90 \%$ of monthly earnings during the last employment spell before entry in the programme.

Table ID.2e: Estimated unsubsidised employment with stable earnings effects 8 years after programme start

\begin{tabular}{|c|c|c|c|c|c|c|c|c|c|c|}
\hline \multirow{2}{*}{ State $\mathrm{m}$} & \multirow{2}{*}{ State I } & \multicolumn{2}{|c|}{ Sample size } & \multirow{2}{*}{$\begin{array}{l}E\left(Y^{m}\right. \\
\mid S=m)\end{array}$} & \multirow{2}{*}{$\begin{array}{l}E\left(Y^{m}\right. \\
\mid S=l)\end{array}$} & \multirow{2}{*}{$\begin{array}{l}E\left(Y^{l}\right. \\
\mid S=m)\end{array}$} & \multirow{2}{*}{$\begin{array}{l}E\left(Y^{l}\right. \\
\mid S=l)\end{array}$} & \multirow[b]{2}{*}{$\theta_{0}^{m, l}$} & \multirow[b]{2}{*}{$-\theta_{0}^{l, m}$} & \multirow[b]{2}{*}{$\gamma_{0}^{m, l}$} \\
\hline & & $\mathrm{m}$ & । & & & & & & & \\
\hline (1) & (2) & (3) & (4) & (5) & (6) & (7) & (8) & (9) & (10) & (11) \\
\hline Short trail & Nonpartic & 292 & 3541 & & 44.2 & 26.8 & 27.4 & $12.6^{*}$ & $16.8^{*}$ & $15.3^{*}$ \\
\hline Short tr & long tre & 292 & 502 & & 36. & 33 & 32. & 6.3 & 33 & 12.7 \\
\hline Short training & Retraining & 292 & 429 & 39.4 & 46.8 & 43.4 & 40.3 & -4.0 & 6.3 & 1.5 \\
\hline Long training & Nonparticip. & 502 & 3541 & 32.9 & 27.1 & 28.7 & 27.4 & 4.2 & -0.3 & 0.6 \\
\hline Long training & Retraining & 502 & 429 & 32.9 & 33.0 & 49.9 & 40.3 & $-17.0^{*}$ & -7.3 & -12.6 \\
\hline Retraining & Nonparticip. & 429 & 3541 & 40.3 & 39.9 & 32.5 & 27.4 & 7.8 & 12.5 & 12.9 \\
\hline
\end{tabular}

Note: $\quad$ Bold numbers indicate significance at the $5 \%$ level, numbers in italics relate to the $10 \%$ level and ${ }^{*}$ to the $1 \%$ level. The outcome variable "unsubsidised employment with stable earnings" is a dummy that equals 1 if earnings (employment other than a temporary wage subsidy or a job creation scheme or a structural adjustment measure) in the respective month are at least $90 \%$ of monthly earnings during the last employment spell before entry in the programme. 
Figure ID.2a: Dynamics of the effects $\left(\theta_{0}^{m, l}\right)$ :(difference in \%-points)

Employment with 'stable' earnings
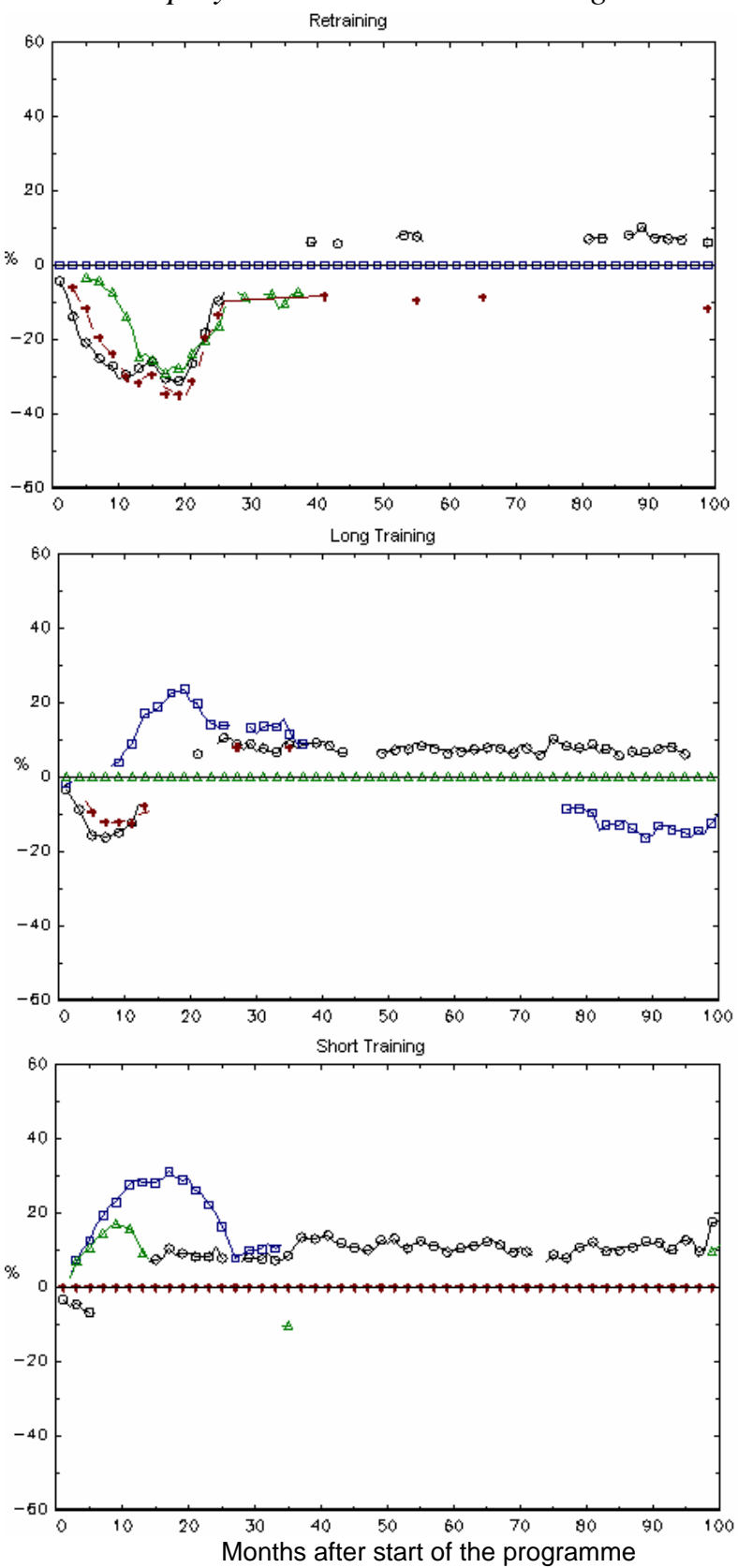

* - Non-participation $\boxminus-$ - Retraining
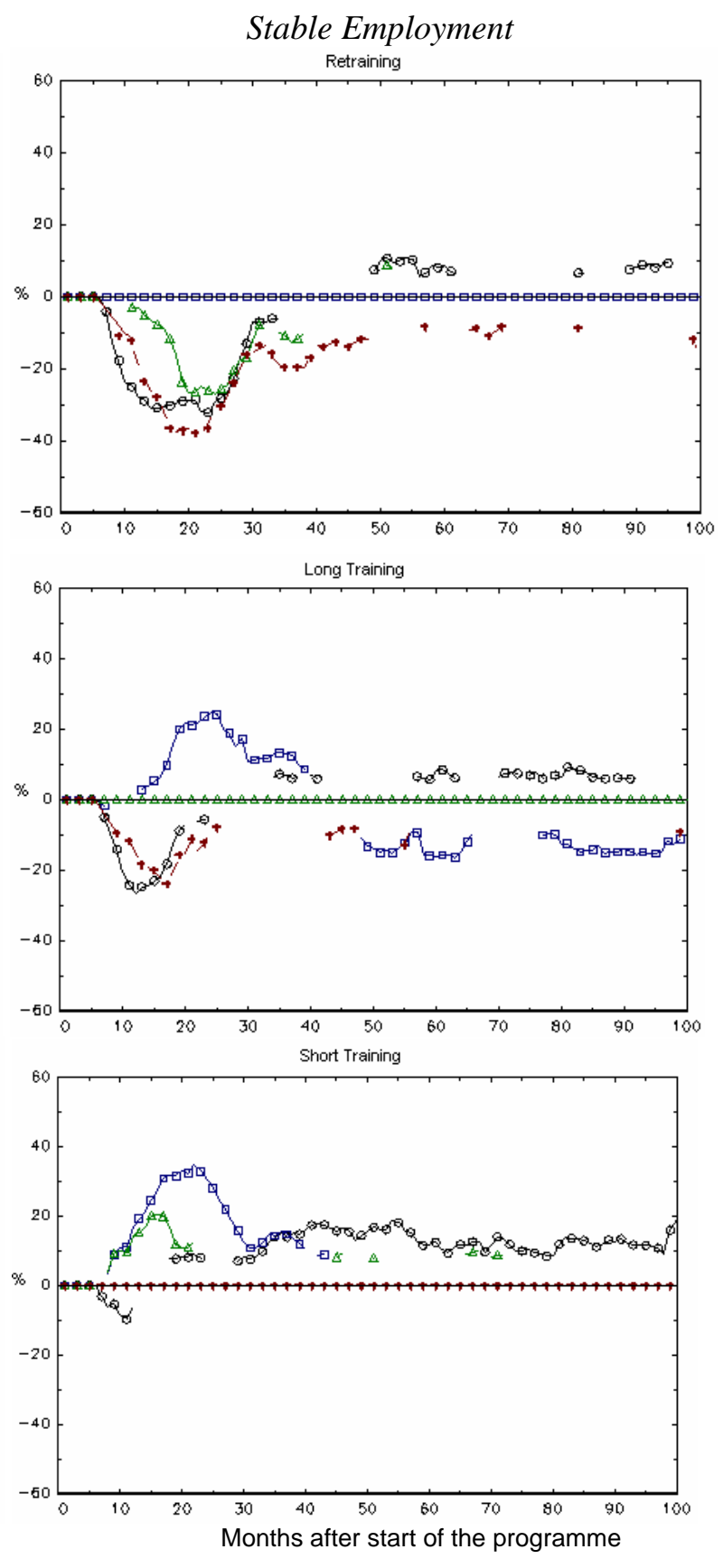

$₫$ Long Training + - Short Training

Note: The outcome variable "employment with stable earnings" is a dummy that equals 1 if earnings in the respective month are at least $90 \%$ of monthly earnings during the last employment spell before entry in the programme. The outcome "stable employment" is a dummy variable which is 1 for a particular month, if the individual is employed in this month as well as in the six months just before. Only effects that are significant at the $5 \%$ level (point wise) appear in the figures. 
Table ID.2f: Estimated stable employment effects 2 and 8 years after programme start

\begin{tabular}{|c|c|c|c|c|c|c|c|c|c|c|}
\hline \multirow{2}{*}{ Outcome } & \multirow{2}{*}{$\begin{array}{c}\text { Month after } \\
\text { beginning }\end{array}$} & \multicolumn{2}{|c|}{ Sample size } & \multirow{2}{*}{$\begin{array}{l}E\left(Y^{m}\right. \\
\mid S=m)\end{array}$} & \multirow{2}{*}{$\begin{array}{l}E\left(Y^{m}\right. \\
\mid S=l)\end{array}$} & \multirow{2}{*}{$\begin{array}{l}E\left(Y^{l}\right. \\
\mid S=m)\end{array}$} & \multirow{2}{*}{$\begin{array}{l}E\left(Y^{l}\right. \\
\mid S=l)\end{array}$} & \multirow[b]{2}{*}{$\theta_{0}^{m, l}$} & \multirow[b]{2}{*}{$-\theta_{0}^{l, m}$} & \multirow[b]{2}{*}{$\gamma_{0}^{m, l}$} \\
\hline & & $\mathrm{m}$ & । & & & & & & & \\
\hline (1) & (2) & (3) & (4) & (5) & (6) & (7) & (8) & (9) & (10) & $(11)$ \\
\hline \multicolumn{11}{|c|}{ Short training $(\mathrm{m})$ compared to nonparticipation $(\mathrm{I})$} \\
\hline \multirow[t]{2}{*}{ Employed } & 24 & 292 & 3542 & 38.4 & 44.4 & 32.8 & 29.0 & 5.6 & $15.4^{*}$ & $14.2^{*}$ \\
\hline & 96 & 292 & 3542 & 44.9 & 49.4 & 33.5 & 32.9 & $11.4^{*}$ & $16.5^{*}$ & $15.0^{*}$ \\
\hline \multicolumn{11}{|c|}{ Short training $(\mathrm{m})$ compared to long training $(\mathrm{l})$} \\
\hline \multirow[t]{2}{*}{ Employed } & 24 & 292 & 502 & 38.4 & 41.8 & 34.1 & 32.9 & 4.3 & 8.9 & 10.4 \\
\hline & 96 & 292 & 502 & 44.9 & 47.9 & 39.0 & 40.2 & 5.9 & 7.7 & 13.4 \\
\hline \multicolumn{11}{|c|}{ Short training $(\mathrm{m})$ compared to retraining $(\mathrm{I})$} \\
\hline \multirow[t]{2}{*}{ Employed } & 24 & 292 & 429 & 38.4 & 39.1 & 8.1 & 7.0 & $30.3^{*}$ & $32.1^{*}$ & $32.2^{*}$ \\
\hline & 96 & 292 & 429 & 44.9 & 49.2 & 48.0 & 44.3 & -3.1 & 4.9 & -0.1 \\
\hline \multicolumn{11}{|c|}{ Long training $(\mathrm{m})$ compared to nonparticipation (I) } \\
\hline \multirow[t]{2}{*}{ Employed } & 24 & 502 & 3542 & 32.9 & 34.2 & 36.8 & 29.0 & -3.9 & 5.2 & 2.7 \\
\hline & 96 & 502 & 3542 & 40.2 & 33.5 & 36.5 & 32.9 & 3.7 & 0.6 & 0.8 \\
\hline \multicolumn{11}{|c|}{ Long training $(\mathrm{m})$ compared to retraining $(\mathrm{l})$} \\
\hline \multirow[t]{2}{*}{ Employed } & 24 & 502 & 429 & 32.9 & 34.0 & 8.0 & 7.0 & $24.9^{*}$ & $27.0^{*}$ & $21.9^{*}$ \\
\hline & 96 & 502 & 429 & 40.2 & 39.7 & 55.1 & 44.3 & $-14.9^{*}$ & -4.6 & -12.6 \\
\hline \multicolumn{11}{|c|}{ Retraining (m) compared to nonparticipation (l) } \\
\hline \multirow[t]{2}{*}{ Employed } & 24 & 429 & 3542 & 7.0 & 14.0 & 36.4 & 29.0 & $-29.4^{*}$ & $-15.0^{\star}$ & $-19.2^{*}$ \\
\hline & 96 & 429 & 3542 & 44.3 & 47.1 & 39.0 & 32.9 & 5.3 & $14.2^{*}$ & $13.5^{*}$ \\
\hline
\end{tabular}

Table ID.2g: Estimated stable unsubsidised employment effects 8 years after programme start

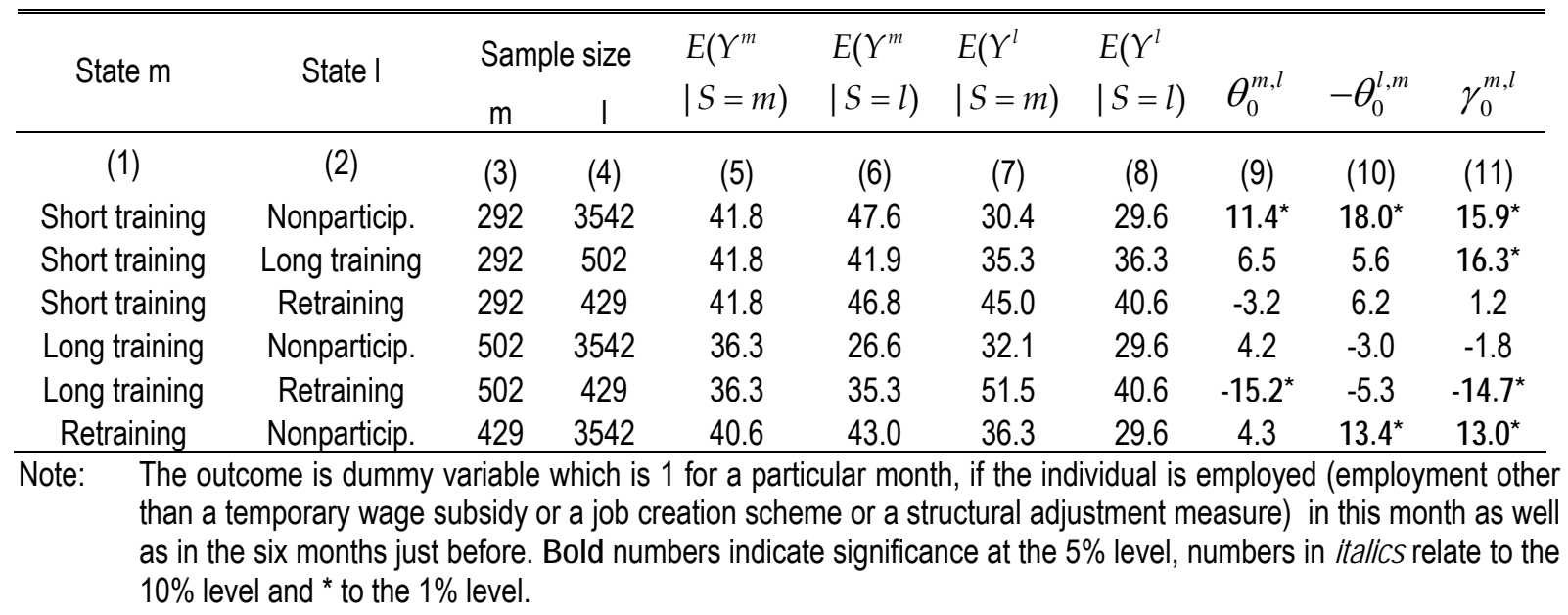


Table ID.2h: Estimated earnings effects 2 and 8 years after programme start

\begin{tabular}{|c|c|c|c|c|c|c|c|c|c|c|}
\hline \multirow{2}{*}{ Outcome } & \multirow{2}{*}{$\begin{array}{c}\text { Month after } \\
\text { beginning }\end{array}$} & \multicolumn{2}{|c|}{ Sample size } & \multirow{2}{*}{$\begin{array}{l}E\left(Y^{m}\right. \\
\mid S=m)\end{array}$} & \multirow{2}{*}{$\begin{array}{l}E\left(Y^{m}\right. \\
\mid S=l)\end{array}$} & \multirow{2}{*}{$\begin{array}{l}E\left(Y^{l}\right. \\
\mid S=m)\end{array}$} & \multirow{2}{*}{$\begin{array}{l}E\left(Y^{l}\right. \\
\mid S=l)\end{array}$} & \multirow[b]{2}{*}{$\theta_{0}^{m, l}$} & \multirow[b]{2}{*}{$-\theta_{0}^{l, m}$} & \multirow{2}{*}{$\gamma_{0}^{m, l}$} \\
\hline & & $\mathrm{m}$ & I & & & & & & & \\
\hline (1) & (2) & (3) & $(4)$ & (5) & (6) & (7) & (8) & (9) & $(10)$ & $(11)$ \\
\hline \multicolumn{11}{|c|}{ Short training $(\mathrm{m})$ compared to nonparticipation (I) } \\
\hline \multirow[t]{2}{*}{ Employed } & 24 & 292 & 3541 & 710 & 877 & 522 & 492 & $188^{*}$ & $385^{*}$ & $344^{*}$ \\
\hline & 96 & 292 & 3541 & 816 & 876 & 608 & 606 & $208^{*}$ & $270^{*}$ & $252^{*}$ \\
\hline \multicolumn{11}{|c|}{ Short training $(\mathrm{m})$ compared to long training $(\mathrm{I})$} \\
\hline \multirow[t]{2}{*}{ Employed } & 24 & 292 & 502 & 710 & 716 & 687 & 740 & 23 & -24 & 113 \\
\hline & 96 & 292 & 502 & 816 & 825 & 761 & 845 & 55 & -20 & 170 \\
\hline \multicolumn{11}{|c|}{ Short training $(\mathrm{m})$ compared to retraining $(\mathrm{l})$} \\
\hline \multirow[t]{2}{*}{ Employed } & 24 & 292 & 429 & 710 & 774 & 393 & 437 & $317^{*}$ & $337^{*}$ & $392^{*}$ \\
\hline & 96 & 292 & 429 & 816 & 956 & 891 & 836 & -75 & 120 & -13 \\
\hline \multicolumn{11}{|c|}{ Long training (m) compared to nonparticipation (I) } \\
\hline \multirow[t]{2}{*}{ Employed } & 24 & 502 & 3541 & 740 & 727 & 597 & 492 & $143^{*}$ & $235^{*}$ & $198^{*}$ \\
\hline & 96 & 502 & 3541 & 845 & 657 & 700 & 606 & 145 & 51 & 61 \\
\hline \multicolumn{11}{|c|}{ Long training $(\mathrm{m})$ compared to retraining $(\mathrm{I})$} \\
\hline \multirow[t]{2}{*}{ Employed } & 24 & 502 & 429 & 740 & 739 & 516 & 437 & $224^{*}$ & $302^{*}$ & $253^{*}$ \\
\hline & 96 & 502 & 429 & 845 & 804 & 947 & 836 & -102 & -32 & -161 \\
\hline \multicolumn{11}{|c|}{ Retraining $(\mathrm{m})$ compared to nonparticipation (I) } \\
\hline \multirow[t]{2}{*}{ Employed } & 24 & 429 & 3541 & 437 & 434 & 595 & 492 & $-158^{*}$ & -58 & -74 \\
\hline & 96 & 429 & 3541 & 836 & 850 & 735 & 606 & 101 & $244^{*}$ & $233^{*}$ \\
\hline
\end{tabular}

Note: $\quad$ Monthly earnings in euros (without benefits). The earnings information is available for a slightly smaller sample than the employment information. Bold numbers indicate significance at the $5 \%$ level, numbers in italics relate to the $10 \%$ level and * to the $1 \%$ level.

Table ID.2i: Estimated unsubsidised earnings effects 8 years after programme start

\begin{tabular}{|c|c|c|c|c|c|c|c|c|c|c|}
\hline \multirow{2}{*}{ State $m$} & \multirow{2}{*}{ State I } & \multicolumn{2}{|c|}{ Sample size } & \multirow{2}{*}{$\begin{array}{l}E\left(Y^{m}\right. \\
\mid S=m)\end{array}$} & \multirow{2}{*}{$\begin{array}{l}E\left(Y^{m}\right. \\
\mid S=l)\end{array}$} & \multirow{2}{*}{$\begin{array}{l}E\left(Y^{l}\right. \\
\mid S=m)\end{array}$} & \multirow{2}{*}{$\begin{array}{l}E\left(Y^{l}\right. \\
\mid S=l)\end{array}$} & \multirow[b]{2}{*}{$\theta_{0}^{m, l}$} & \multirow[b]{2}{*}{$-\theta_{0}^{l, m}$} & \multirow[b]{2}{*}{$\gamma_{0}^{m, l}$} \\
\hline & & $\mathrm{m}$ & 1 & & & & & & & \\
\hline (1) & (2) & (3) & (4) & (5) & (6) & (7) & (8) & (9) & (10) & (11) \\
\hline Short training & Nonparticip. & 292 & 3541 & 751 & 837 & 534 & 530 & $217^{*}$ & $307^{*}$ & $276^{*}$ \\
\hline Short training & Long training & 292 & 502 & 751 & 739 & 714 & 767 & 37 & -28 & 183 \\
\hline Short training & Retraining & 292 & 429 & 751 & 912 & 835 & 765 & -84 & 147 & 20 \\
\hline Long training & Nonparticip. & 502 & 3541 & 767 & 590 & 631 & 530 & 136 & 60 & 67 \\
\hline Long training & Retraining & 502 & 429 & 767 & 748 & 875 & 765 & -108 & -17 & -147 \\
\hline Retraining & Nonparticip. & 429 & 3541 & 765 & 768 & 681 & 530 & 87 & $238^{*}$ & $224^{*}$ \\
\hline
\end{tabular}

Note: Monthly earnings in euros (without benefits, employment other than a temporary wage subsidy or a job creation scheme or a structural adjustment measure). The earnings information is available for a slightly smaller sample than the employment information. Bold numbers indicate significance at the $5 \%$ level, numbers in italics relate to the $10 \%$ level and ${ }^{*}$ to the $1 \%$ level. 
Figure ID.2b: Dynamics of the effects $\left(\theta_{0}^{m, l}\right)$ : Monthly earnings
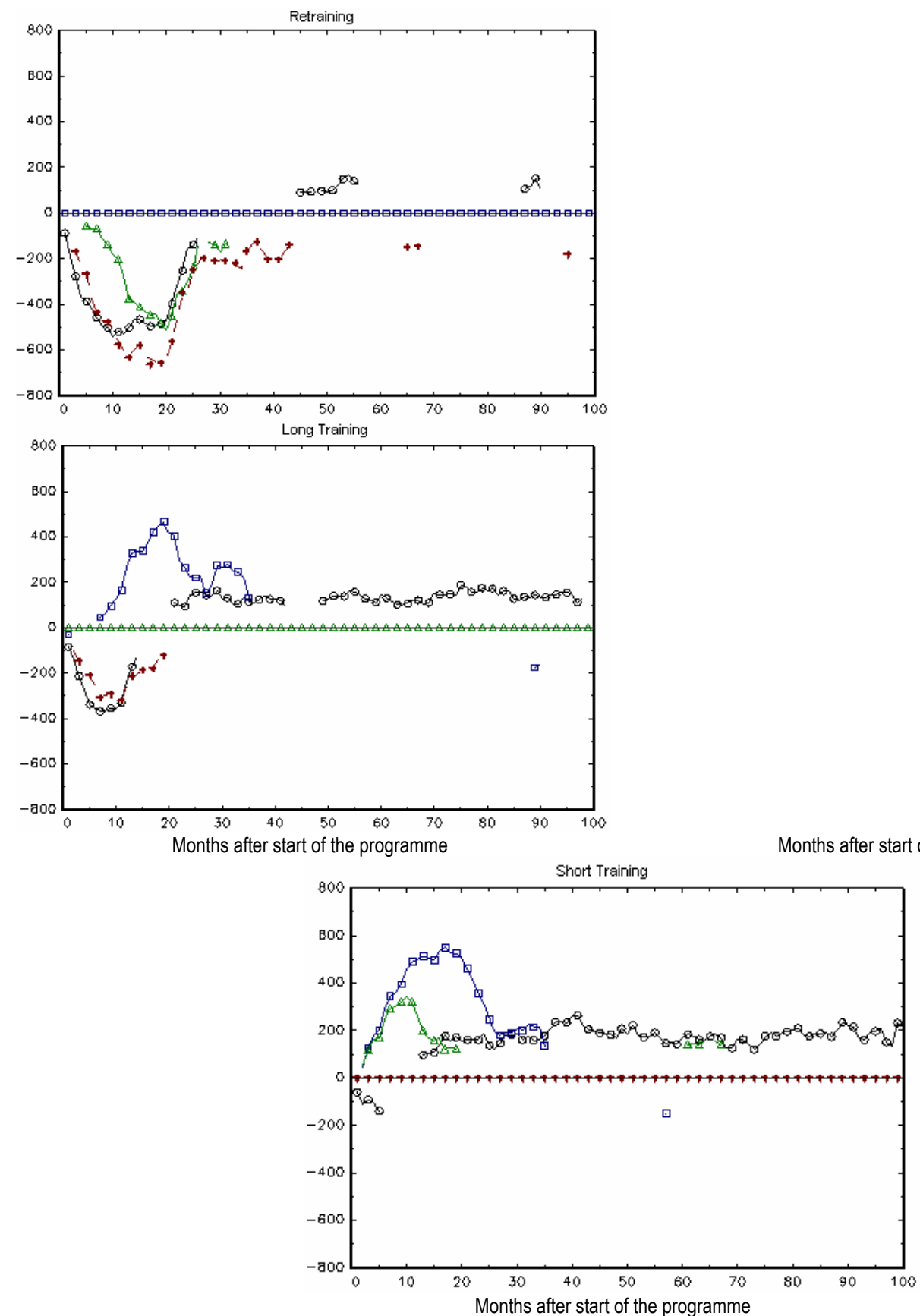

* - Non-participation $\bullet--$ Retraining $\&$ Long Training + - Short Training

Note: Earnings differences in Euros. Only effects that are significant at the $5 \%$ level (point wise) appear in the figures. 
Table ID.2j: Estimated smooth employment effects 2 and 8 years after programme start

\begin{tabular}{|c|c|c|c|c|c|c|c|c|c|c|}
\hline \multirow{2}{*}{ Outcome } & \multirow{2}{*}{$\begin{array}{c}\text { Month after } \\
\text { beginning }\end{array}$} & \multicolumn{2}{|c|}{ Sample size } & \multirow{2}{*}{$\begin{array}{l}E\left(Y^{m}\right. \\
\mid S=m)\end{array}$} & \multirow{2}{*}{$\begin{array}{l}E\left(Y^{m}\right. \\
\mid S=l)\end{array}$} & \multirow{2}{*}{$\begin{array}{l}E\left(Y^{l}\right. \\
\mid S=m)\end{array}$} & \multirow{2}{*}{$\begin{array}{l}E\left(Y^{l}\right. \\
\mid S=l)\end{array}$} & \multirow[b]{2}{*}{$\theta_{0}^{m, l}$} & \multirow[b]{2}{*}{$-\theta_{0}^{l, m}$} & \multirow[b]{2}{*}{$\gamma_{0}^{m, l}$} \\
\hline & & $\mathrm{m}$ & I & & & & & & & \\
\hline (1) & (2) & (3) & (4) & (5) & (6) & (7) & (8) & (9) & (10) & $(11)$ \\
\hline \multicolumn{11}{|c|}{ Short training $(\mathrm{m})$ compared to nonparticipation (I) } \\
\hline \multirow[t]{2}{*}{ Employed } & 24 & 292 & 3542 & 52.4 & 67.4 & 42.3 & 39.3 & 10.1 & $28.1^{*}$ & $23.9 *$ \\
\hline & 96 & 292 & 3542 & 52.4 & 55.0 & 40.5 & 39.6 & $11.9^{*}$ & $15.4^{*}$ & $14.3^{*}$ \\
\hline \multicolumn{11}{|c|}{ Short training $(\mathrm{m})$ compared to long training $(\mathrm{l})$} \\
\hline \multirow[t]{2}{*}{ Employed } & 24 & 292 & 502 & 52.4 & 52.2 & 52.5 & 52.4 & -0.1 & -0.2 & 7.1 \\
\hline & 96 & 292 & 502 & 52.4 & 51.8 & 47.6 & 47.5 & 4.8 & 4.3 & 9.6 \\
\hline \multicolumn{11}{|c|}{ Short training $(\mathrm{m})$ compared to retraining $(\mathrm{I})$} \\
\hline \multirow[t]{2}{*}{ Employed } & 24 & 292 & 429 & 52.4 & 53.8 & 32.3 & 33.2 & $20.1^{*}$ & $20.6^{*}$ & $29.2^{*}$ \\
\hline & 96 & 292 & 429 & 52.4 & 59.9 & 56.5 & 52.4 & -4.1 & 7.5 & 0.0 \\
\hline \multicolumn{11}{|c|}{ Long training $(\mathrm{m})$ compared to nonparticipation (l) } \\
\hline \multirow[t]{2}{*}{ Employed } & 24 & 502 & 3542 & 52.4 & 56.4 & 45.5 & 39.3 & 6.9 & $17.1^{*}$ & $14.3^{*}$ \\
\hline & 96 & 502 & 3542 & 47.5 & 43.3 & 43.6 & 39.6 & 3.9 & 3.7 & 3.4 \\
\hline \multicolumn{11}{|c|}{ Long training (m) compared to retraining $(\mathrm{I})$} \\
\hline \multirow[t]{2}{*}{ Employed } & 24 & 502 & 429 & 52.4 & 55.1 & 36.5 & 33.2 & $15.9^{*}$ & $21.9^{*}$ & $20.2^{*}$ \\
\hline & 96 & 502 & 429 & 47.5 & 46.7 & 60.4 & 52.4 & $-12.9^{*}$ & -5.7 & -9.1 \\
\hline \multicolumn{11}{|c|}{ Retraining (m) compared to nonparticipation (I) } \\
\hline \multirow[t]{2}{*}{ Employed } & 24 & 429 & 3542 & 33.2 & 33.6 & 46.6 & 39.3 & $-13.4^{*}$ & -5.7 & -7.1 \\
\hline & 96 & 429 & 3542 & 52.4 & 52.2 & 45.5 & 39.6 & 6.9 & 12.6 & $12.5^{\star}$ \\
\hline
\end{tabular}

Note: $\quad$ Bold numbers indicate significance at the $5 \%$ level, numbers in italics relate to the $10 \%$ level and ${ }^{*}$ to the $1 \%$ level. The outcome is the mean over three months of the employment state.

Table ID.2k: Estimated smooth unsubsidised employment effects 8 years after programme start

\begin{tabular}{|c|c|c|c|c|c|c|c|c|c|c|}
\hline \multirow{2}{*}{ State $\mathrm{m}$} & \multirow{2}{*}{ State I } & \multicolumn{2}{|c|}{ Sample size } & \multirow{2}{*}{$\begin{array}{l}E\left(Y^{m}\right. \\
\mid S=m)\end{array}$} & \multirow{2}{*}{$\begin{array}{l}E\left(Y^{m}\right. \\
\mid S=l)\end{array}$} & \multirow{2}{*}{$\begin{array}{l}E\left(Y^{l}\right. \\
\mid S=m)\end{array}$} & \multirow{2}{*}{$\begin{array}{l}E\left(Y^{l}\right. \\
\mid S=l)\end{array}$} & \multirow[b]{2}{*}{$\theta_{0}^{m, l}$} & \multirow[b]{2}{*}{$-\theta_{0}^{l, m}$} & \multirow[b]{2}{*}{$\gamma_{0}^{m, l}$} \\
\hline & & $\mathrm{m}$ & I & & & & & & & \\
\hline (1) & (2) & (3) & (4) & (5) & (6) & (7) & (8) & (9) & (10) & (11) \\
\hline Short training & Nonparticip. & 292 & 3542 & 46.9 & 51.7 & 34.2 & 33.6 & $12.7^{*}$ & $18.1^{*}$ & $16.2^{*}$ \\
\hline Short training & Long training & 292 & 502 & 46.9 & 44.4 & 43.3 & 41.4 & 3.6 & 3.0 & 11.5 \\
\hline Short training & Retraining & 292 & 429 & 46.9 & 56.4 & 52.5 & 47.2 & -5.6 & 9.2 & 2.1 \\
\hline Long training & Nonparticip. & 502 & 3542 & 41.4 & 36.6 & 38.0 & 33.6 & 3.4 & 3.0 & 2.9 \\
\hline Long training & Retraining & 502 & 429 & 41.4 & 42.2 & 55.3 & 47.2 & $-13.9^{*}$ & -5.0 & -9.5 \\
\hline Retraining & Nonparticip. & 429 & 3542 & 47.2 & 45.9 & 40.9 & 33.6 & 6.3 & 12.3 & $12.3^{*}$ \\
\hline
\end{tabular}

Note: $\quad$ Bold numbers indicate significance at the $5 \%$ level, numbers in italics relate to the $10 \%$ level and ${ }^{*}$ to the $1 \%$ level. The outcome is the mean over three months of the employment state (employment other than a temporary wage subsidy or a job creation scheme or a structural adjustment measure). 
Figure ID.2c: Dynamics of the effects: Smoothed effect
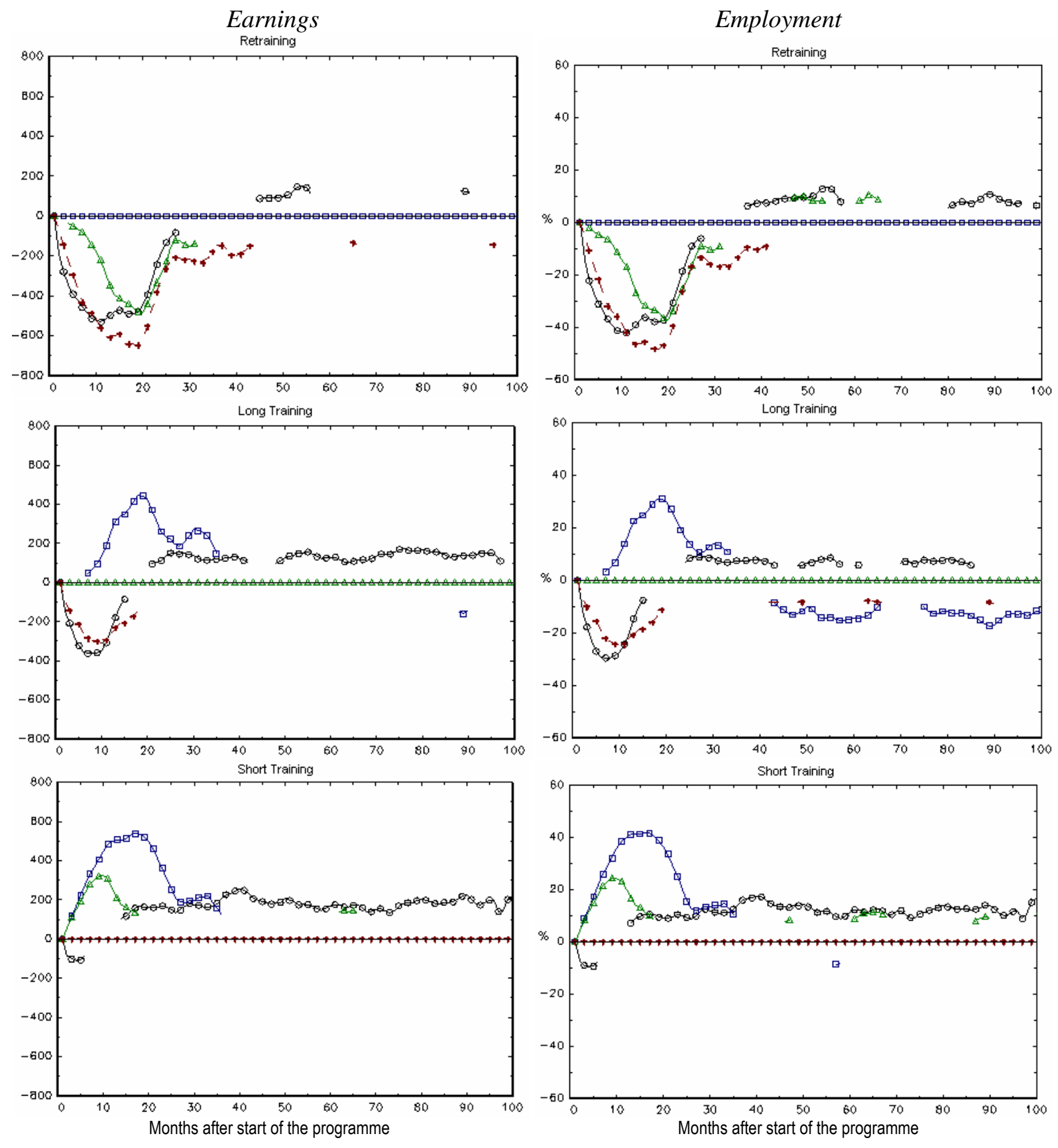

๑ - Non-participation $\boxminus--$ Retraining

\& Long Training + - Short Training

Note: The outcome "employment" is a moving average over three months of the employment state. The outcome "earnings" is the moving average over three months of the earnings observations. Only effects that are significant at the $5 \%$ level (point wise) appear in the figures. 
Table ID.2l: Estimated smooth earnings effects 2 and 8 years after programme start

\begin{tabular}{|c|c|c|c|c|c|c|c|c|c|c|}
\hline \multirow{2}{*}{ Outcome } & \multirow{2}{*}{$\begin{array}{c}\text { Month after } \\
\text { beginning }\end{array}$} & \multicolumn{2}{|c|}{ Sample size } & \multirow{2}{*}{$\begin{array}{l}E\left(Y^{m}\right. \\
\mid S=m)\end{array}$} & \multirow{2}{*}{$\begin{array}{l}E\left(Y^{m}\right. \\
\mid S=l)\end{array}$} & \multirow{2}{*}{$\begin{array}{l}E\left(Y^{l}\right. \\
\mid S=m)\end{array}$} & \multirow{2}{*}{$\begin{array}{l}E\left(Y^{l}\right. \\
\mid S=l)\end{array}$} & \multirow[b]{2}{*}{$\theta_{0}^{m, l}$} & \multirow[b]{2}{*}{$-\theta_{0}^{l, m}$} & \multirow{2}{*}{$\gamma_{0}^{m, l}$} \\
\hline & & $\mathrm{m}$ & I & & & & & & & \\
\hline (1) & (2) & (3) & $(4)$ & (5) & (6) & (7) & (8) & (9) & $(10)$ & $(11)$ \\
\hline \multicolumn{11}{|c|}{ Short training $(\mathrm{m})$ compared to nonparticipation (I) } \\
\hline \multirow[t]{2}{*}{ Employed } & 24 & 292 & 3541 & 686 & 840 & 524 & 490 & $162^{*}$ & $350^{*}$ & $306^{*}$ \\
\hline & 96 & 292 & 3541 & 810 & 872 & 611 & 595 & $199 *$ & $277^{*}$ & $254^{*}$ \\
\hline \multicolumn{11}{|c|}{ Short training $(\mathrm{m})$ compared to long training $(\mathrm{I})$} \\
\hline \multirow[t]{2}{*}{ Employed } & 24 & 292 & 502 & 686 & 697 & 683 & 734 & 3 & -37 & 82 \\
\hline & 96 & 292 & 502 & 810 & 820 & 775 & 848 & 35 & -28 & 149 \\
\hline \multicolumn{11}{|c|}{ Short training $(\mathrm{m})$ compared to retraining $(\mathrm{l})$} \\
\hline \multirow[t]{2}{*}{ Employed } & 24 & 292 & 429 & 686 & 737 & 379 & 427 & $307^{*}$ & $310^{*}$ & $364^{*}$ \\
\hline & 96 & 292 & 429 & 810 & 963 & 887 & 825 & -77 & 138 & -6 \\
\hline \multicolumn{11}{|c|}{ Long training (m) compared to nonparticipation (I) } \\
\hline \multirow[t]{2}{*}{ Employed } & 24 & 502 & 3541 & 734 & 727 & 604 & 490 & $130^{*}$ & $237^{*}$ & $195^{*}$ \\
\hline & 96 & 502 & 3541 & 848 & 680 & 710 & 595 & 138 & 85 & 84 \\
\hline \multicolumn{11}{|c|}{ Long training $(\mathrm{m})$ compared to retraining $(\mathrm{I})$} \\
\hline \multirow[t]{2}{*}{ Employed } & 24 & 502 & 429 & 734 & 720 & 498 & 427 & $236^{*}$ & $293^{*}$ & $259^{*}$ \\
\hline & 96 & 502 & 429 & 848 & 824 & 929 & 825 & -81 & -1 & -128 \\
\hline \multicolumn{11}{|c|}{ Retraining $(\mathrm{m})$ compared to nonparticipation (I) } \\
\hline \multirow[t]{2}{*}{ Employed } & 24 & 429 & 3541 & 427 & 428 & 610 & 490 & $-183^{*}$ & -62 & -83 \\
\hline & 96 & 429 & 3541 & 825 & 838 & 747 & 595 & 78 & $243^{*}$ & $224^{*}$ \\
\hline
\end{tabular}

Note: $\quad$ Bold numbers indicate significance at the $5 \%$ level, numbers in italics relate to the $10 \%$ level and ${ }^{*}$ to the $1 \%$ level. The outcome is the mean over three months of the earnings.

Table ID.2m: Estimated smooth unsubsidised earnings effects 8 years after programme start

\begin{tabular}{cccccccccccc}
\hline \hline \multirow{2}{*}{ State $\mathrm{m}$} & \multirow{2}{*}{ State I } & \multicolumn{2}{c}{ Sample size } & \multicolumn{2}{c}{$E\left(Y^{m}\right.$} & \multicolumn{2}{c}{$E\left(Y^{m}\right.$} & $E\left(Y^{l}\right.$ & $E\left(Y^{l}\right.$ & & \\
& & $\mathrm{m}$ & $\mid$ & $\mid S=m)$ & $\mid S=l)$ & $\mid S=m)$ & $\mid S=l)$ & $\theta_{0}^{m, l}$ & $-\theta_{0}^{l, m}$ & $\gamma_{0}^{m, l}$ \\
\hline (1) & $(2)$ & $(3)$ & $(4)$ & $(5)$ & $(6)$ & $(7)$ & $(8)$ & $(9)$ & $(10)$ & $(11)$ \\
Short training & Nonparticip. & 292 & 3541 & 746 & 836 & 634 & 521 & $\mathbf{2 1 2 ^ { * }}$ & $\mathbf{3 1 5 ^ { * }}$ & $\mathbf{2 8 2 ^ { * }}$ \\
Short training & long training & 292 & 502 & 746 & 733 & 726 & 767 & 20 & -34 & 168 \\
Short training & Retraining & 292 & 429 & 746 & 922 & 832 & 758 & -86 & 163 & 30 \\
Long training & Nonparticip. & 502 & 3541 & 767 & 608 & 635 & 521 & 132 & 87 & 86 \\
Long training & Retraining & 502 & 429 & 767 & 858 & 862 & 758 & -95 & 10 & -120 \\
Retraining & Nonparticip. & 429 & 3541 & 758 & 755 & 687 & 521 & 71 & $\mathbf{2 3 4 ^ { * }}$ & $\mathbf{2 1 7 ^ { * }}$ \\
\hline
\end{tabular}

Note: $\quad$ Bold numbers indicate significance at the $5 \%$ level, numbers in italics relate to the $10 \%$ level and ${ }^{*}$ to the $1 \%$ level. The outcome is the mean over three months of the earnings (employment other than a temporary wage subsidy or a job creation scheme or a structural adjustment measure). 
Figure ID.2d: Dynamics of employment effects by gender (difference in \%-points)
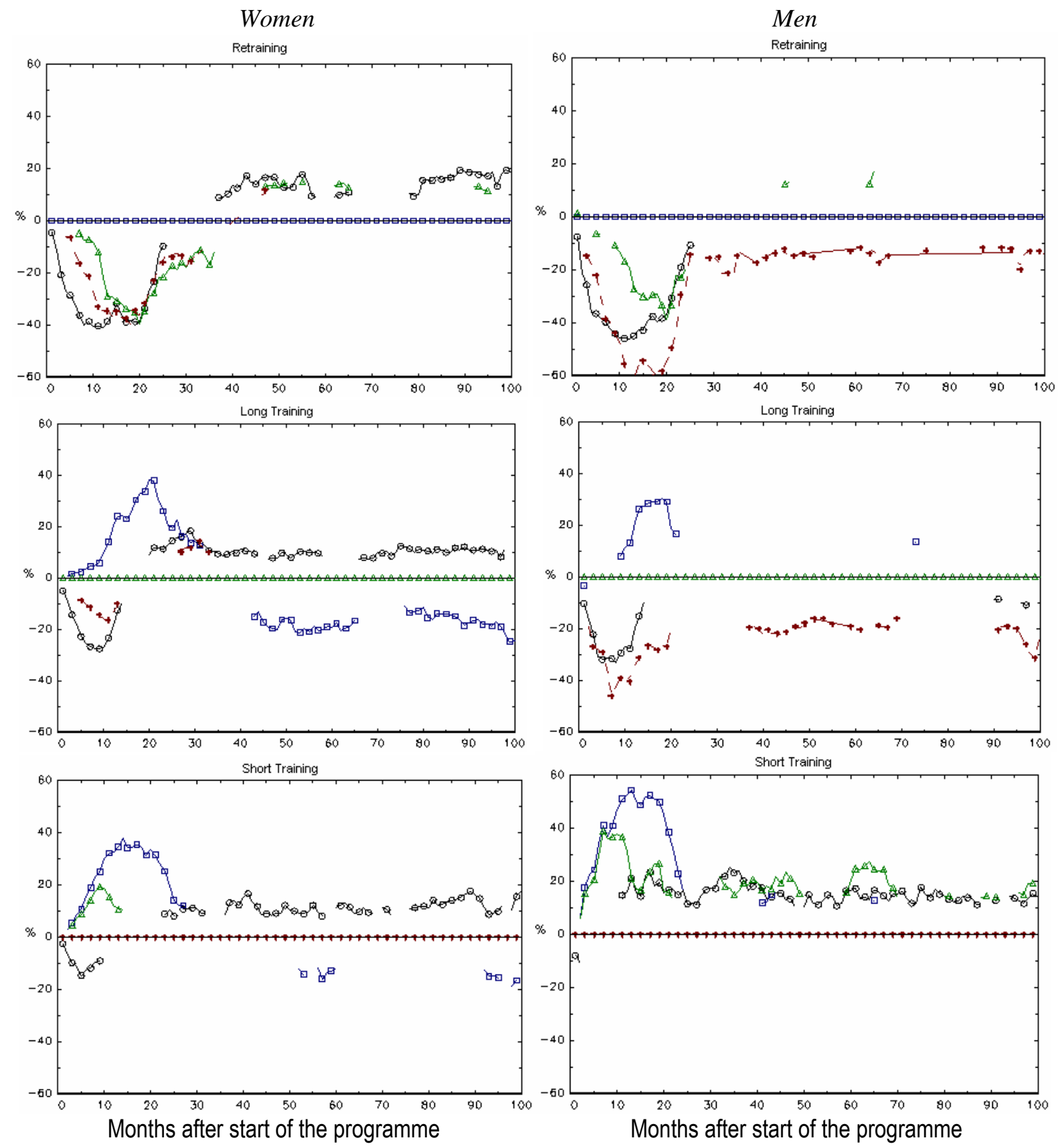

* - Non-participation $\quad$ - - Retraining $\&$ Long Training +- Short Training

Note: Outcome: subsidised and unsubsidised employment. Only effects that are significant at the $5 \%$ level (point wise) appear in the figures. 
Figure ID.2e: Dynamics of employment effects by gender (difference in \%-points) -

MNP estimation different for men and women

Women
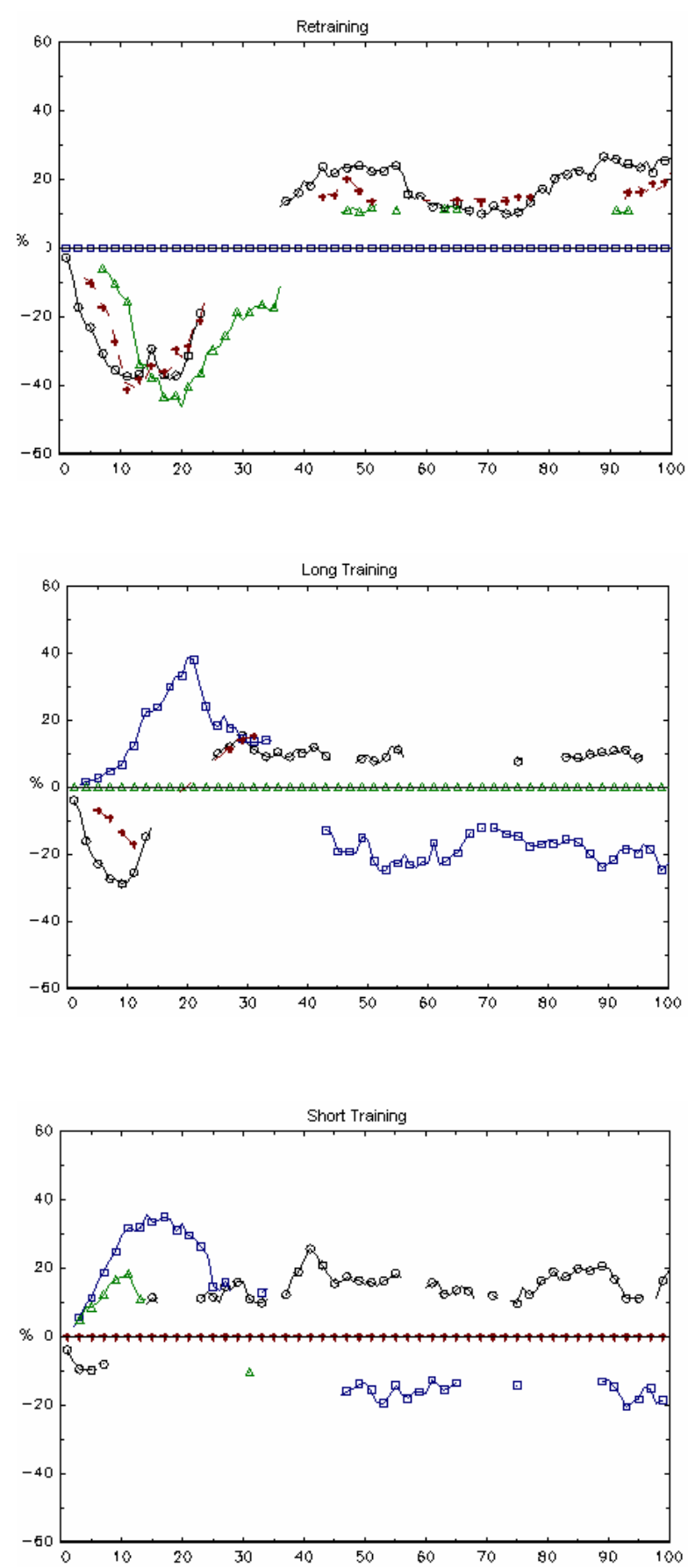

Months after start of the programme
Men
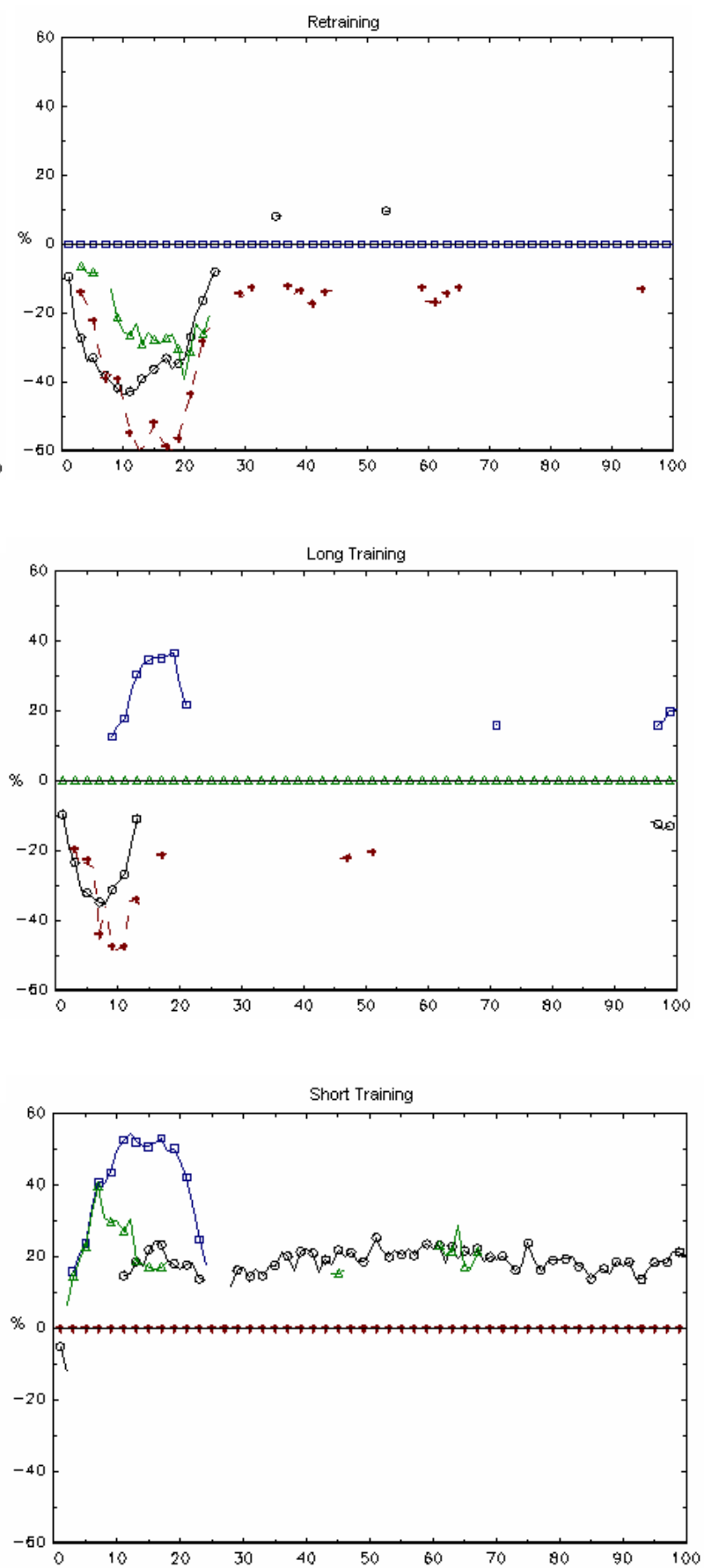

Months after start of the programme

$$
\text { * - Non-participation } \quad \text { - - Retraining } \& \text { Long Training + - Short Training }
$$

Note: Outcome: subsidised and unsubsidised employment. Only effects that are significant at the $5 \%$ level (point wise) appear in the figures. 
Figure ID.2f: Dynamics of monthly earnings effects by gender - MNP estimation different for men and women
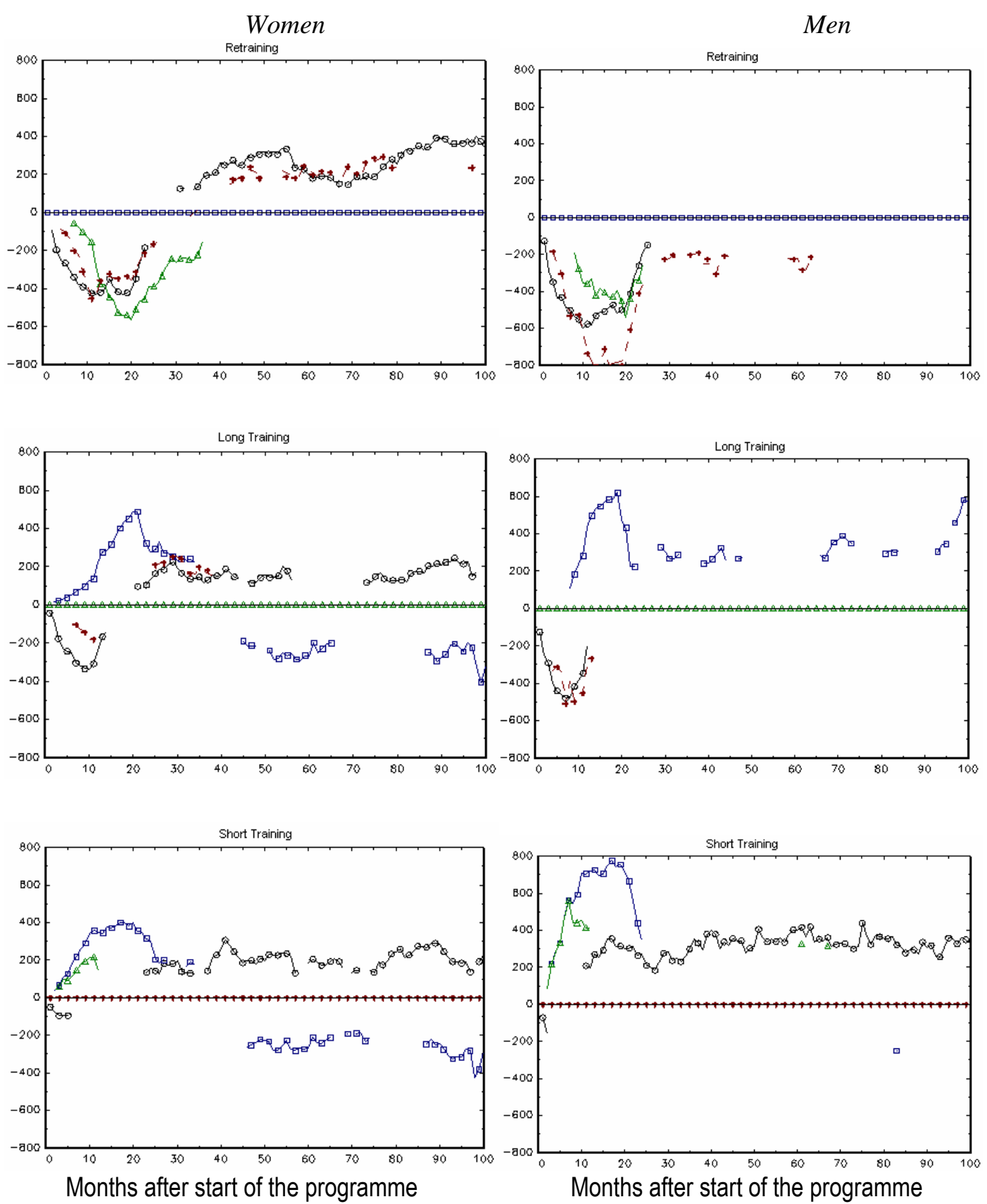

* - Non-participation $\bullet--$ Retraining \& Long Training + - Short Training

Note: Outcome: subsidised and unsubsidised employment. Only effects that are significant at the $5 \%$ level (point wise) appear in the figures. 
Figure ID.2g: Dynamics of employment effects by gender (difference in \%-points) -

MNP different for men and women, without Berlin
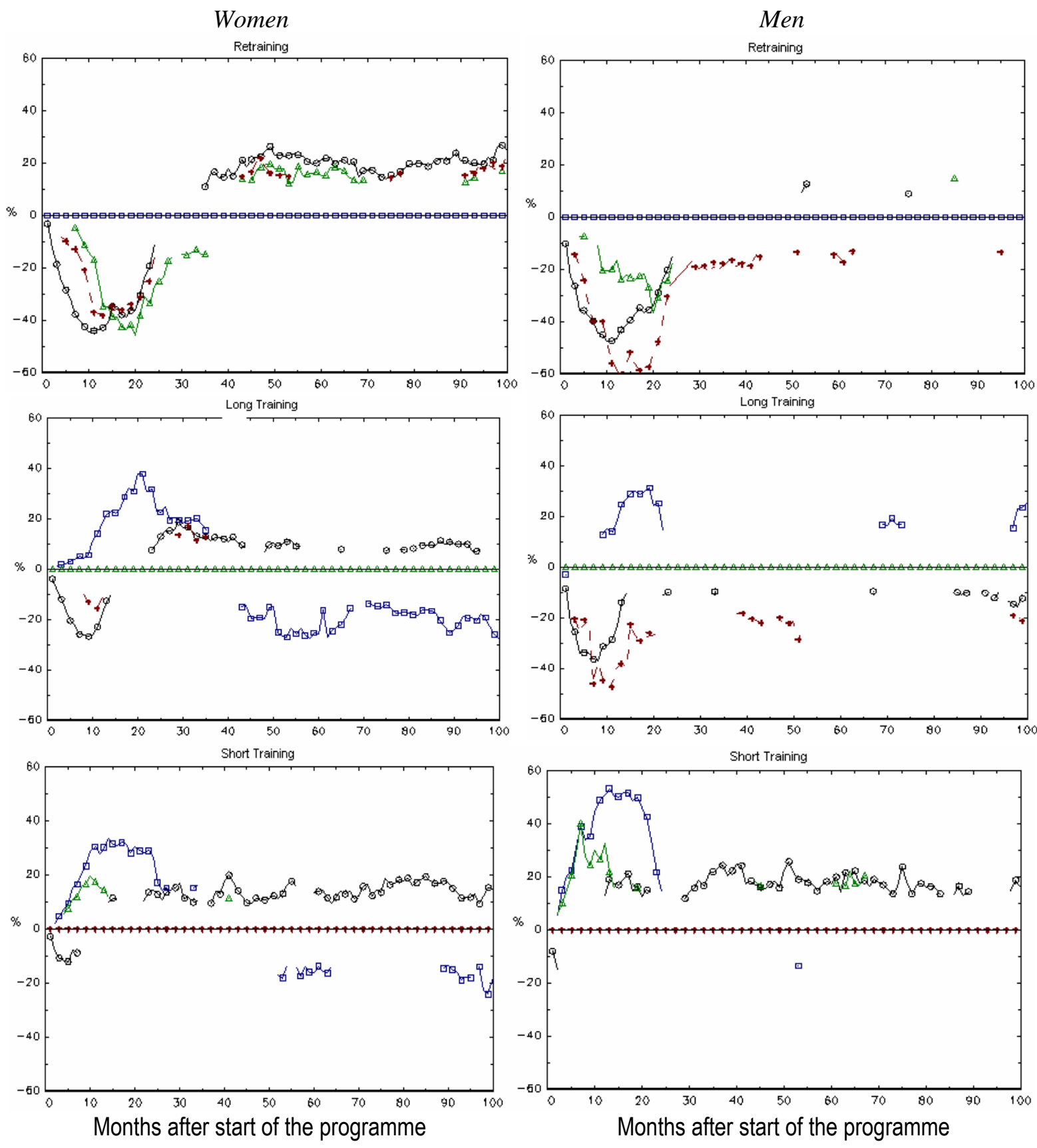

* - Non-participation $\quad$-- Retraining \& Long Training + - Short Training

Note: Outcome: subsidised and unsubsidised employment. Only effects that are significant at the $5 \%$ level (point wise) appear in the figures. 


\section{Appendix ID.3: Effect heterogeneity}

Table ID.3a: Effect heterogeneity 8 years after programme start (difference in \%-points) $\left(\theta_{0}^{m, l}\right)$ -

Separate MNP estimation for men and women

\begin{tabular}{|c|c|c|c|c|}
\hline & \multicolumn{2}{|c|}{ Employment } & \multicolumn{2}{|c|}{ Unsubsidised Employment } \\
\hline$m-1$ & Men & Women & Men & Women \\
\hline Short training - nonparticipation & $18.7^{*}$ & 11.8 & $20.7^{*}$ & 11.7 \\
\hline Short training - long training & 15.5 & -0.4 & 13.7 & -2.8 \\
\hline Short training - retraining & 0.2 & -14.7 & -0.8 & -17.5 \\
\hline Long training - nonparticipation & -11.7 & 9.4 & -11.2 & $11.0^{*}$ \\
\hline Long training - short training & -13.4 & 4.7 & 0.7 & 3.2 \\
\hline Long training - retraining & 1.6 & -17.0 & 1.5 & $-19.5^{\star}$ \\
\hline Retraining - nonparticipation & 1.2 & $25.3^{*}$ & 0.8 & $25.5^{*}$ \\
\hline Retraining - short training & -9.3 & 16.3 & -11.1 & 13.7 \\
\hline Retraining - long training & 7.6 & 6.5 & 7.9 & 3.4 \\
\hline Nonparticipation & 1252 & 1888 & 1252 & 1888 \\
\hline Short training & 98 & 160 & 98 & 160 \\
\hline Long training & 159 & 292 & 159 & 292 \\
\hline Retraining & 232 & 161 & 232 & 161 \\
\hline
\end{tabular}

Note: $\quad$ Bold numbers indicate significance at the $5 \%$ level, numbers in italics relate to the $10 \%$ level and ${ }^{*}$ to the $1 \%$ level. Cells shaded in grey indicate that the difference of the two estimated effects is significant at the $5 \%$ level. Employment is the combination of subsidised and nonsubsidised employment.

Table ID.3b: Effect heterogeneity 8 years after programme start $\left(\theta_{0}^{m, l}\right)$ - Separate MNP estimation for men and women

\begin{tabular}{l|cc|cc|}
\hline \hline \multicolumn{1}{c|}{ m - I } & \multicolumn{2}{|c|}{ Earnings } & \multicolumn{2}{c|}{ Unsubsidised Earnings } \\
\hline Short training - nonparticipation & Men & Women & Men & Women \\
Short training - long training & $355^{*}$ & 190 & $397^{*}$ & 197 \\
Short training - retraining & 142 & -79 & 124 & -106 \\
Long training - nonparticipation & -84 & -275 & -94 & -307 \\
Long training - short training & -96 & $228^{*}$ & -102 & $245^{*}$ \\
Long training - retraining & 16 & 136 & 125 & 114 \\
Retraining - nonparticipation & 227 & -199 & 231 & -236 \\
Retraining - short training & 4 & $386^{*}$ & -1 & $397^{*}$ \\
Retraining - long training & -154 & 198 & -182 & 169 \\
Nonparticipation & 80 & -16 & 84 & -51 \\
Short training & 1251 & 1888 & 1251 & 1888 \\
Long training & 98 & 160 & 98 & 160 \\
Retraining & 159 & 292 & 159 & 292 \\
\hline
\end{tabular}

Note: Bold numbers indicate significance at the $5 \%$ level, numbers in italics relate to the $10 \%$ level and * to the $1 \%$ level. Cells shaded in grey indicate that the difference of the two estimated effects is significant at the $5 \%$ level. The outcome 'unsubsidised earnings' is the monthly earnings in euros (without benefits, employment other than a temporary wage subsidy or a Job creation scheme or a structural adjustment measure). The outcome 'earnings' is the monthly earnings in euros (without benefits). 
Table ID.3c: Effect heterogeneity (employment) 8 years after programme start (difference in \%-points) $\left(\theta_{0}^{m, l}\right)$

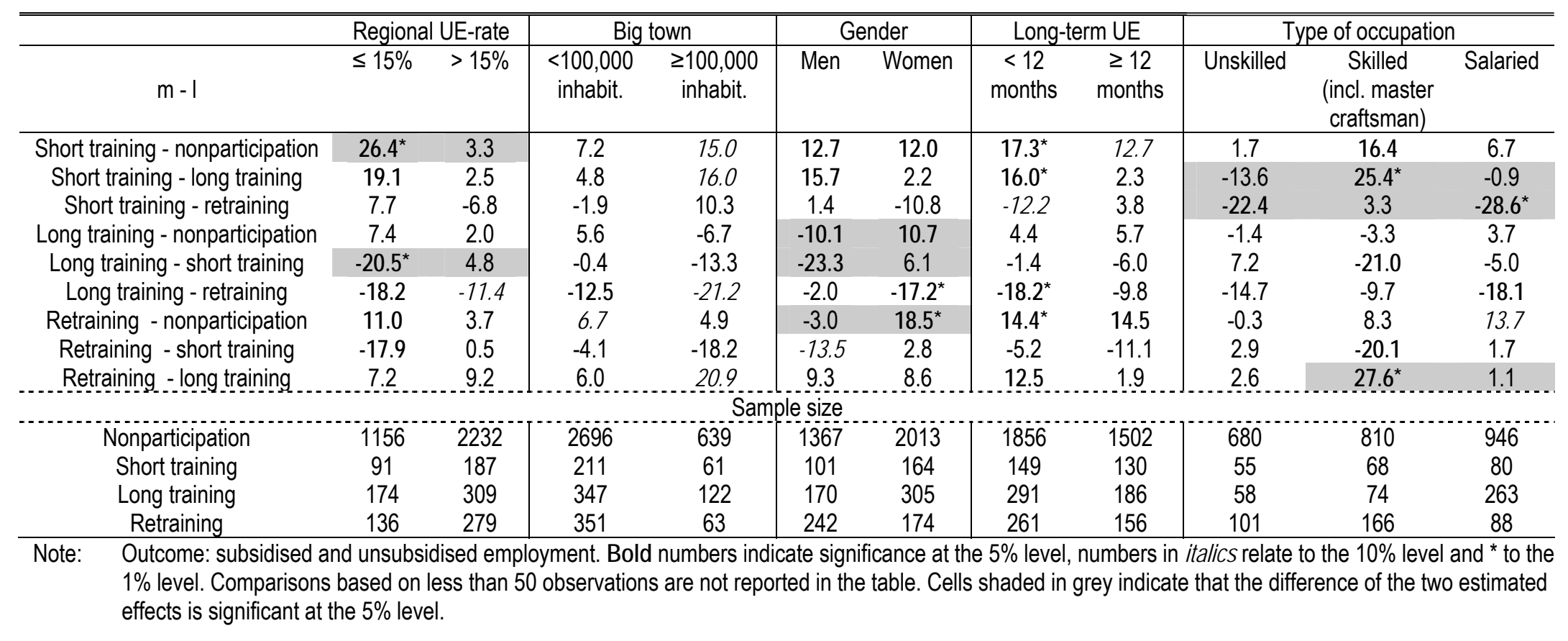




\section{Appendix IE: Results of the sensitivity analysis}

\section{Appendix IE.1: Different procedure for simulating starting dates for nonparticipants}

Figure IE.1: Dynamics of the effects $\left(\hat{\theta}_{t}^{m l}\right)$ after the start of the programme (differences in \%-points)

(alternative starting dates for nonparticipants)

Employment
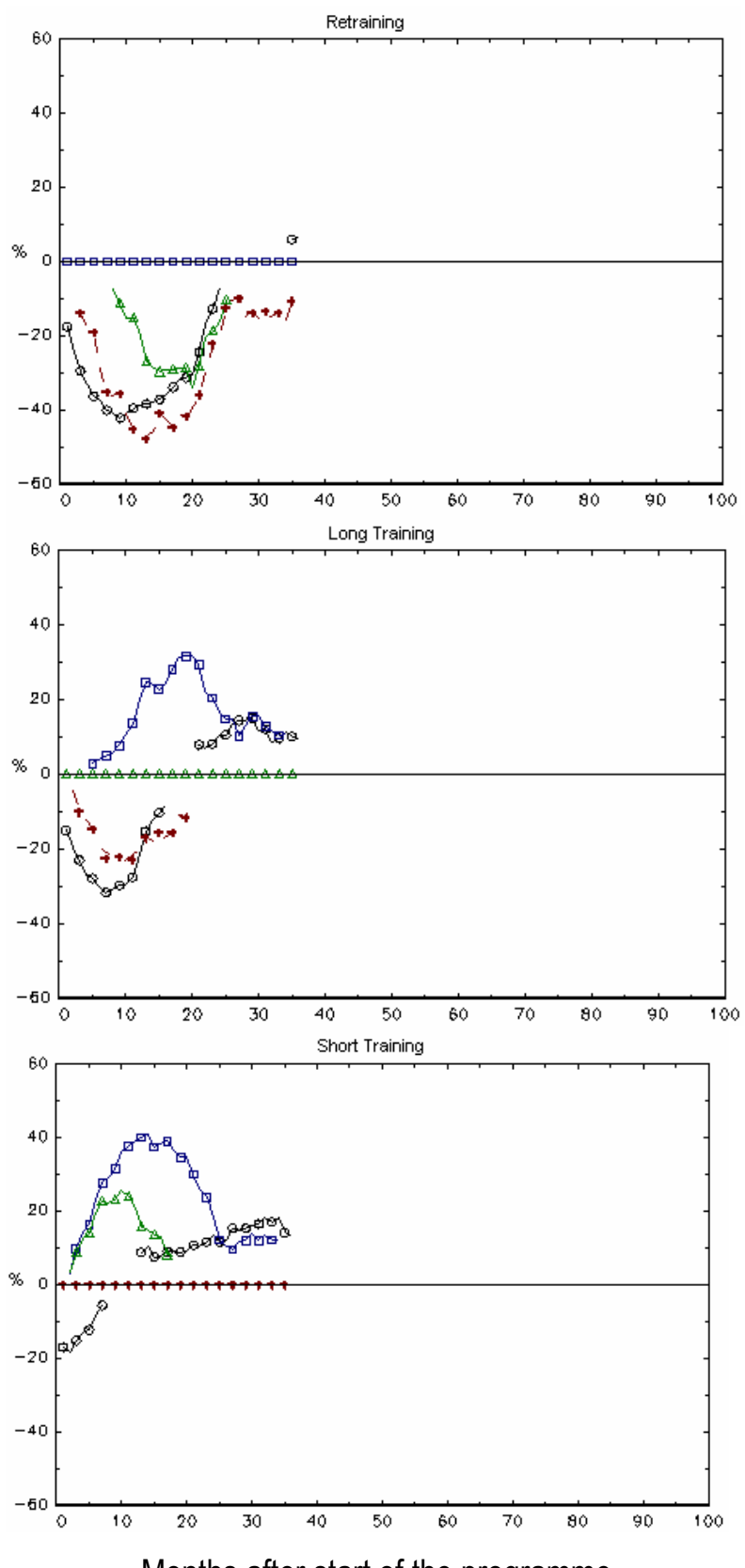

Months after start of the programme

๑ - Non-participation $\boxminus-$ - Retraining
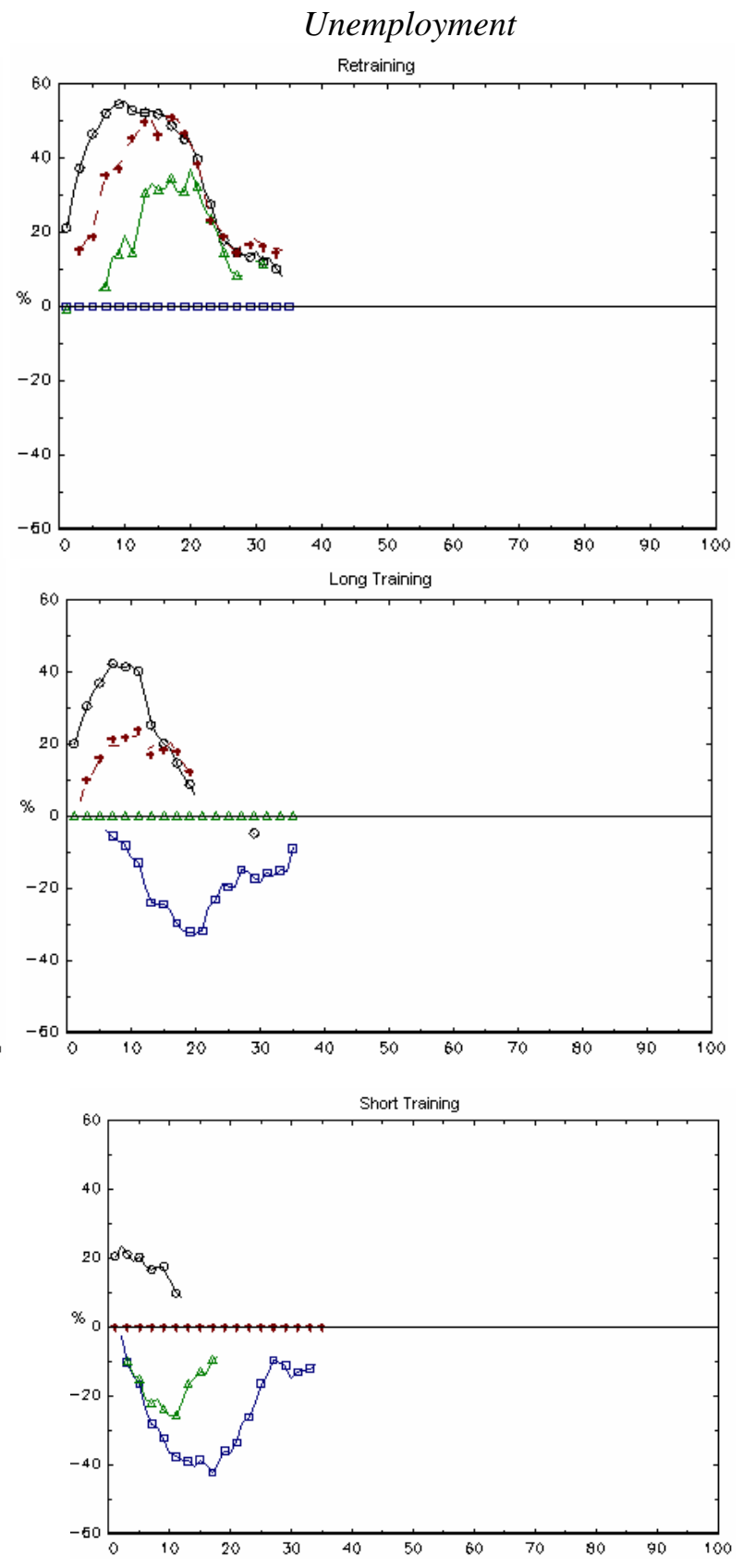

Months after start of the programme

\& Long Training + - Short Training

Note: $\quad$ Outcome: subsidised and unsubsidised employment. Only effects that are significant at the 5\% level (point wise) appear in the figures. The effects can be displayed only for up to 36 months (1997) since we have the data until 2002 only available for the evaluation sample we have chosen originally. 
Appendix IE.2: Stricter common support: Defining maximum and minimum using the $10^{\text {th }}$ largest/smallest observations

Figure IE.2a: Distribution of marginal probabilities after imposing redefined common support rule
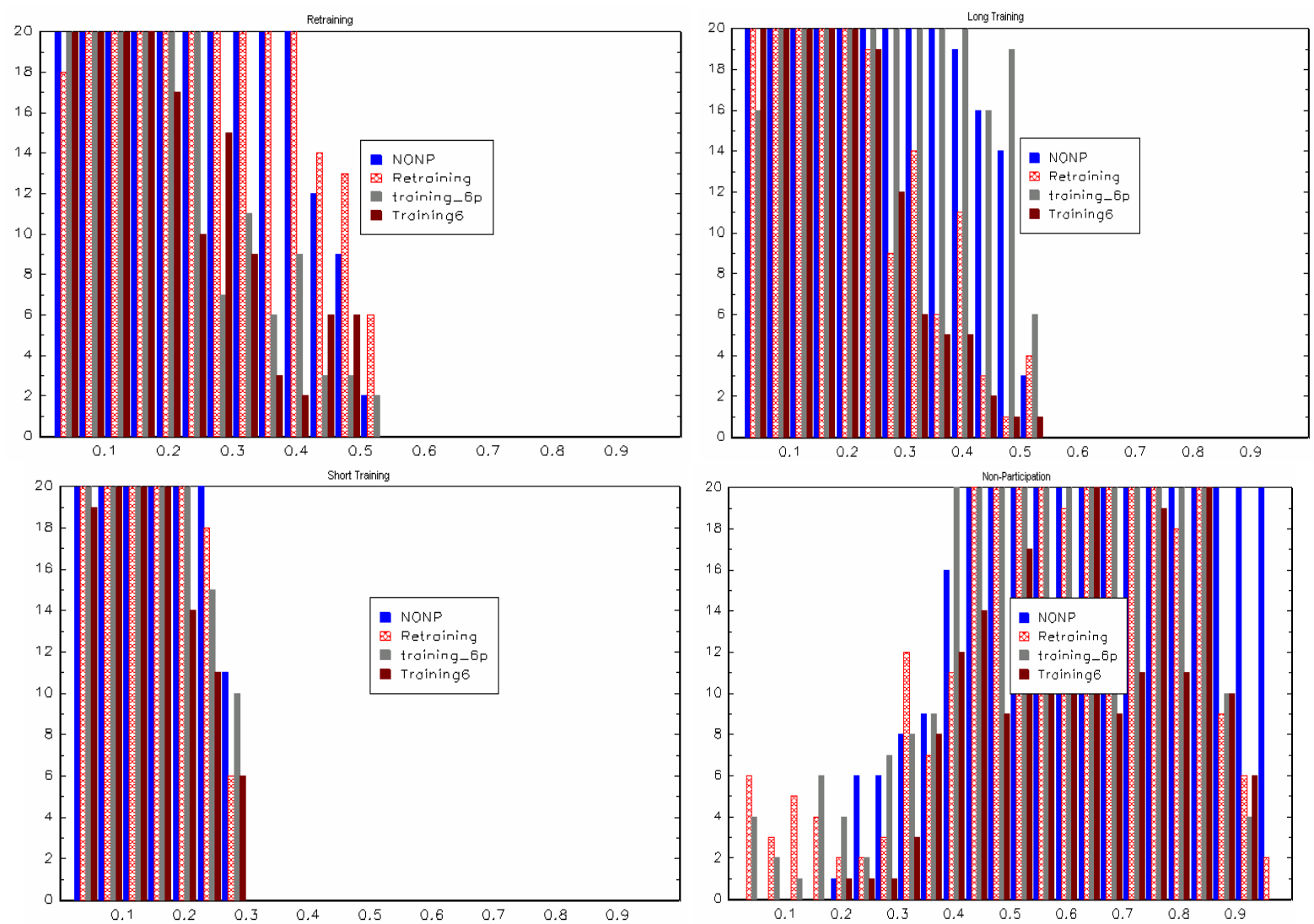
Figure IE.2b: Dynamics of the effects $\left(\theta_{0}^{m, l}\right)$ : Employment (difference in \%-points)
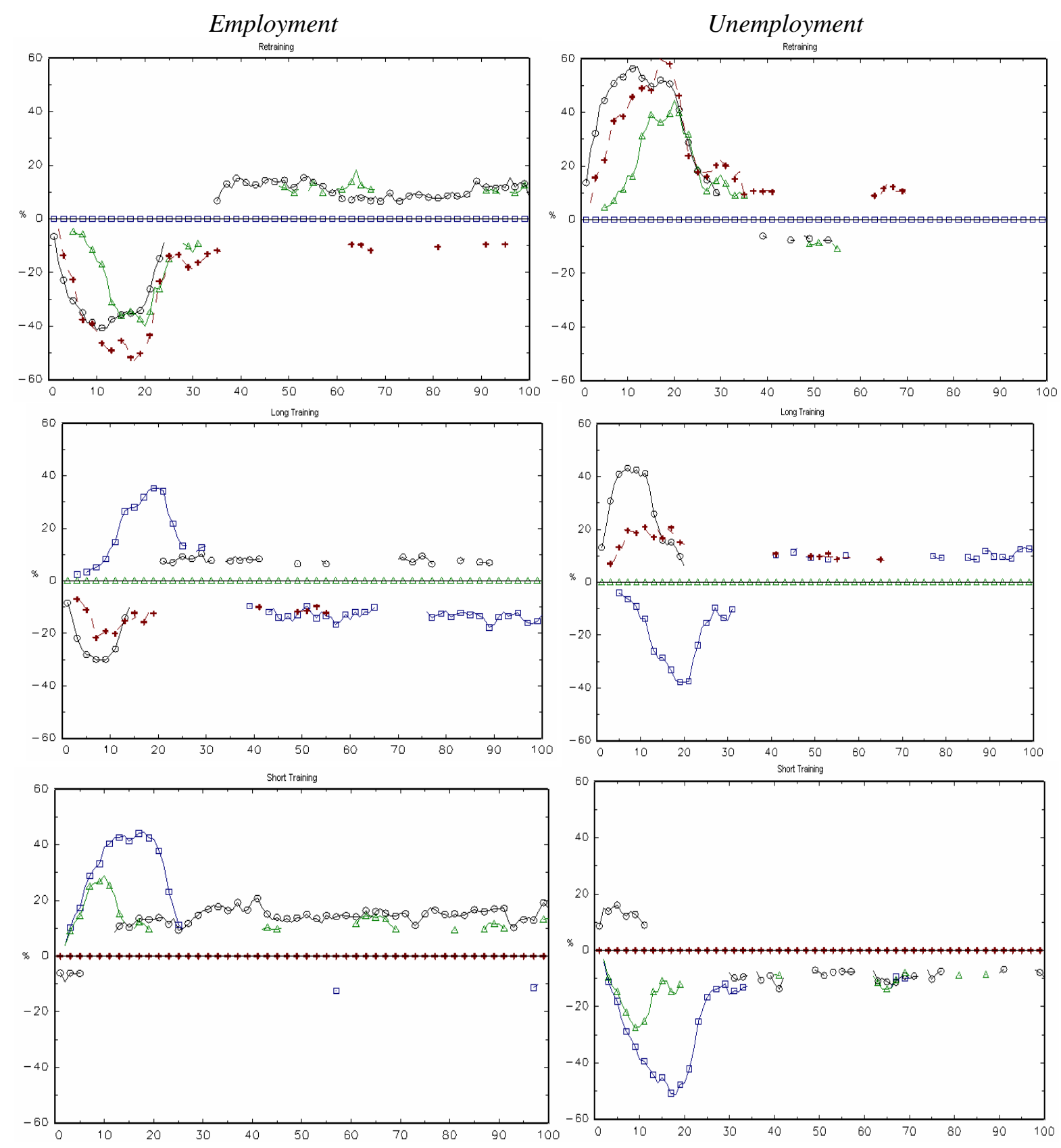

Months after start of the programme

Months after start of the programme

$$
\text { * Non-participation } \boxminus-- \text { Retraining } ₫ \text { Long Training + - Short Training }
$$

Note: Outcome: subsidised and unsubsidised employment. Only effects that are significant at the $5 \%$ level (point wise) appear in the figures. Deleted observations in \%: nonparticipants 53.7, short training 38.6, long training 35.3, retraining 23.8 . 


\section{Appendix IE.3: Only gender and the scores used in matching}

Figure IE.3: Dynamics of the effects $\left(\theta_{0}^{m, l}\right)$ : Employment (difference in \%-points)

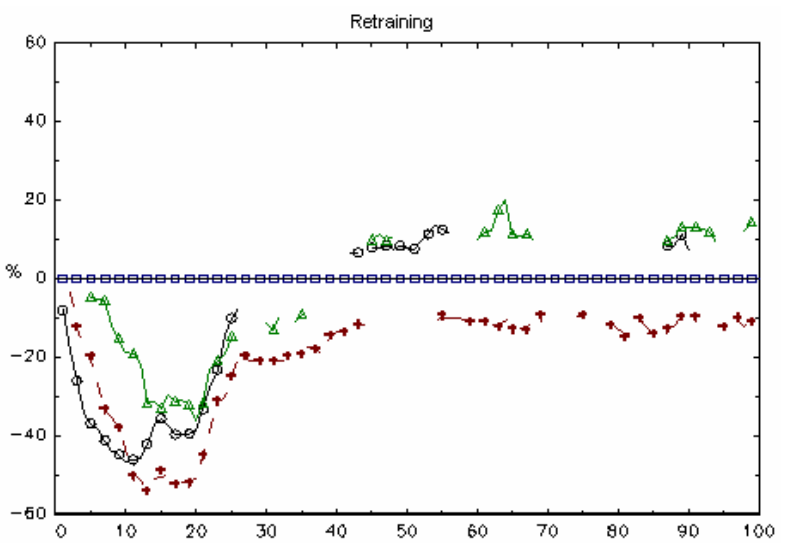

Months after start of the programme

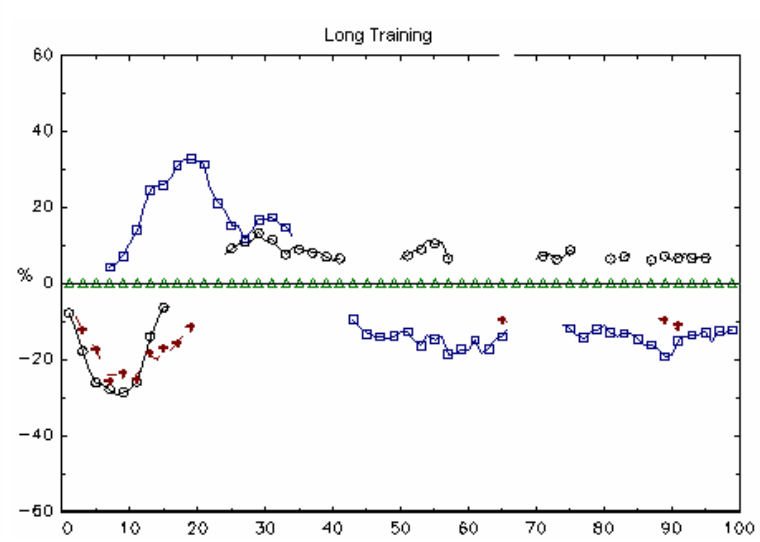

Months after start of the programme

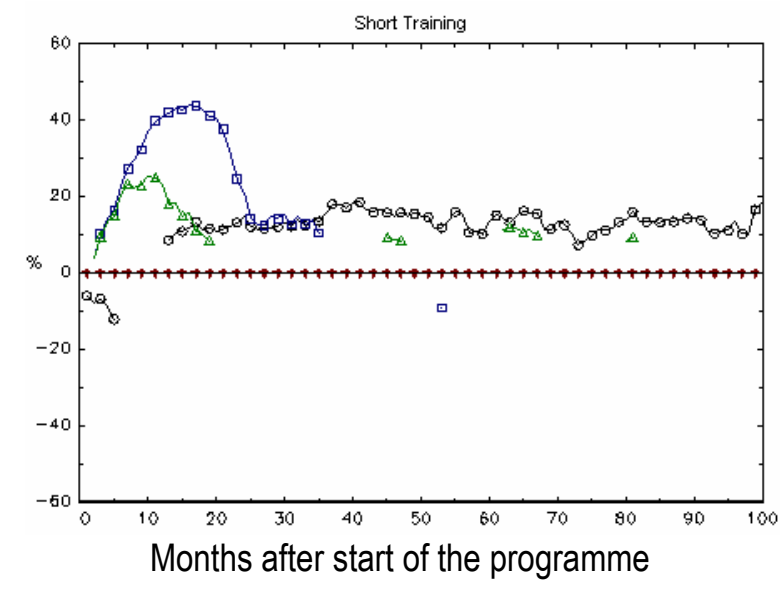

* - Non-participation $\boxminus--$ Retraining \& Long Training + - Short Training

Note: Outcome: subsidised and unsubsidised employment. Only effects that are significant at the $5 \%$ level (point wise) appear in the figures. 


\section{Appendix IF: Selected asymptotic bias estimates}

Figure IF.1: Bias in terms of employment differences $\left(\sum_{\tau=1}^{t} \hat{\theta}_{\tau}^{m l}\right)$ in months
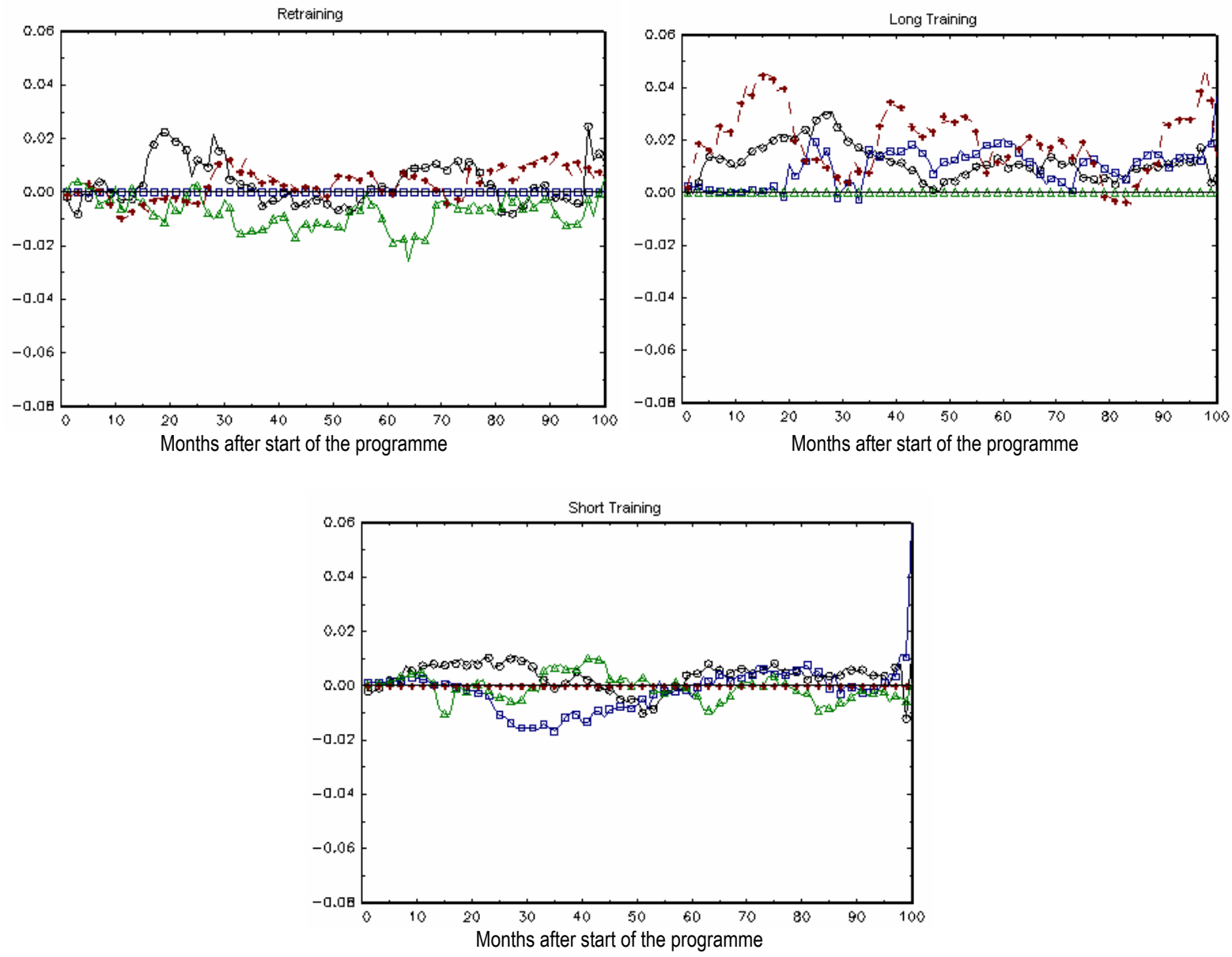

๑ - Non-participation $\quad$-- Retraining \& Long Training + - Short Training

Note: Outcome: subsidised and unsubsidised employment. Only effects that are significant at the $5 \%$ level (point wise) appear in the figures. 